bioRxiv preprint doi: https://doi.org/10.1101/2020.12.15.422921; this version posted December 22, 2020. The copyright holder for this preprint

(which was not certified by peer review) is the author/funder, who has granted bioRxiv a license to display the preprint in perpetuity. It is made available under aCC-BY-NC-ND 4.0 International license.

\title{
ROR $\alpha$ enforces stability of the T-helper-17 cell effector program
}

June-Yong Lee ${ }^{1,3}$, Jason A. Hall ${ }^{1,3}$, Maria Pokrovskii ${ }^{1,3}$, Lina Kroehling ${ }^{1}$, Lin $\mathrm{Wu}^{1}$, and Dan R. $\operatorname{Littman}^{1,2^{*}}$.

1. The Kimmel Center for Biology and Medicine of the Skirball Institute, New York University

School of Medicine, New York, NY 10016, USA

2. Howard Hughes Medical Institute, New York, NY 10016, USA.

3. Contributed equally

*Correspondence: Dan.Littman@med.nyu.edu 
Summary: T helper 17 (Th17) cells regulate mucosal barrier defenses, but also promote multiple autoinflammatory diseases. Although many molecular determinants of Th17 cell differentiation have been described, the transcriptional programs that sustain Th17 cells in vivo remain obscure. The transcription factor $\mathrm{ROR} \gamma \mathrm{t}$ is critical for Th17 cell differentiation, but a distinct role of the closely-related ROR $\alpha$, which is co-expressed in Th17 cells, is not known. Here we demonstrate that, although dispensable for Th17 cell differentiation, ROR $\alpha$ governs optimal Th17 responses in peripheral tissues. Thus, the absence of ROR $\alpha$ in T cells led to significant reductions in both ROR $\gamma$ t expression and effector function amongst Th17 cells, due to need for cooperative ROR $\alpha$ and ROR $\gamma$ t binding to a newly-identified Rorc enhancer element that is essential for Th17 lineage maintenance in vivo. Altogether, these data point to a nonredundant role of ROR $\alpha$ in Th17 lineage maintenance via reinforcement of the ROR $\gamma \mathrm{t}$ transcriptional program.

Key-words: experimental autoimmune encephalomyelitis (EAE), autoimmunity, heat-labile enterotoxin, segmented filamentous bacteria (SFB), gene regulation 


\section{Introduction}

T-helper-17 (Th17) cells and related IL-17-producing (Type-17) lymphocytes are abundant at epithelial barrier sites (Honda and Littman, 2016). Their signature cytokines, IL-17A, IL-17F and IL-22, mediate an antimicrobial immune response and also contribute to wound healing and regeneration of injured tissues upon bacterial and fungal infection (Brockmann et al., 2017; Honda and Littman, 2016; Song et al., 2015). However, these cells are also key drivers of multiple chronic inflammatory diseases, including autoimmune diseases and inflammatory bowel disease (IBD), and they have also been implicated in carcinogenesis (Patel and Kuchroo, 2015; Stockinger and Omenetti, 2017). Ultimately, a better understanding of Type-17 regulatory mechanisms may uncover effective therapeutic strategies aimed at treating chronic inflammatory diseases and reducing cancer incidence.

The differentiation of Th17 cells and their ability to produce signature cytokines depend upon induction of the nuclear receptor (NR) transcription factor RAR-Related Orphan Receptorgamma $t(R O R \gamma t)$. ROR $\gamma t$ is required for the differentiation of both homeostatic Th17 cells, such as those that regulate commensal microbiota at mucosal barriers, and pro-inflammatory Th17 cells, whose dysregulation results in autoimmune and chronic inflammatory diseases.

Therefore, identification of the context-dependent requirements for ROR $\gamma$ t expression may facilitate understanding and therapeutic control of inflammatory immune responses. Studies conducted by our group and others have identified some of the trans-acting factors necessary for regulating transcription of Rorc(t) in Th17 cells (Ciofani et al., 2012; Durant et al., 2010;

Schraml et al., 2009). However, the genomic cis-regulatory elements that control expression of ROR $\gamma \mathrm{t}$ in Th17 cells in vivo have been only partially characterized (Chang et al., 2020; Tanaka et al., 2014).

ROR $\gamma$ t was initially characterized as the "master regulator" of the Th17 effector program. However, another ROR family transcription factor, ROR $\alpha$, is also upregulated during Th17 cell 
differentiation, can direct expression of IL-17 (Huh et al., 2011), and was reported to contribute to Th17 cell function (Castro et al., 2017; Yang et al., 2008). Our transcriptional regulatory network analysis of Th17 cells also identified ROR $\alpha$ as a key Th17-promoting transcription factor (TF) (Ciofani et al., 2012; Miraldi et al., 2019). By exploring the divergent effects of ROR $\alpha$ and ROR $\gamma$ t in Th17-driven autoimmune pathogenesis, we found that ROR $\alpha$ is crucial for the functional maintenance of the Th17 program, despite exerting a relatively minor influence during differentiation of these cells. Thus, there was reduced accumulation of Th17 cells devoid of ROR $\alpha$ in inflamed tissues, which manifested as a dampened pathogenic program. Analysis of chromatin occupancy and accessibility revealed that ROR $\alpha$ binds to an enhancer element within the Rorc (gene for $\mathrm{ROR} \gamma$ and $\mathrm{ROR} \gamma \mathrm{t}$ ) locus and positively regulates $\mathrm{ROR} \gamma \mathrm{t}$ expression during chronic autoimmune inflammation. Taken together, these findings suggest that ROR $\alpha$ functions as a key regulator for the Th17 effector program through direct regulation of sustained ROR $\gamma \mathrm{t}$ expression during chronic inflammation.

\section{Results}

\section{ROR $\alpha$ and ROR $\gamma$ t are differentially required for Th17-mediated EAE pathogenesis}

Although it is established that ROR $\gamma \mathrm{t}$ is required for Th17 cell differentiation, it has been reported that ROR $\alpha$ can partially compensate for ROR $\gamma$ t deficiency to promote Th17-dependent experimental autoimmune encephalomyelitis (EAE) (Yang et al., 2008). To study whether these nuclear receptors exert distinct functions in Th17 cells, we studied mice harboring conditional deletions of Rorc and/or Rora in T cells. In line with previous studies, EAE disease was undetectable $(10 / 18)$ or mild $(8 / 18)$ in $C D 4^{\text {Cre }} \operatorname{Rorc}^{f / f f l}\left(T_{G K O}\right)$ mice, compared to littermate $C D 4^{\text {Cre }}$ Rorc wt ( $\left.\mathrm{T}_{\mathrm{WT}}\right)$ animals, which uniformly developed disease following immunization with myelin oligodendrocyte glycoprotein (MOG) in complete Freund's adjuvant (CFA) and pertussis toxin (Ptx) injection (Figures $1 \mathrm{~A}-\mathrm{C}$ ). To determine whether $\mathrm{T}_{\mathrm{GK}}$ cells were able to differentiate 
into Th17 cells in a setting permissive to fulminant EAE disease, we induced EAE in lethallyirradiated Rag1 deficient mice that had been reconstituted with an equal number of isotypemarked CD45.1/2 $\mathrm{T}_{\mathrm{WT}}$ and CD45.2 $\mathrm{T}_{\mathrm{GKO}}$ bone marrow cells. In this context, although all mice developed severe EAE, only cells of wild type origin were found to produce IL-17A in the draining lymph nodes (DLN) and spinal cord (SC). Conversely, the proportions of IFN $\gamma$ producing cells were similar among $\mathrm{T}_{\mathrm{WT}}$ and $\mathrm{T}_{\mathrm{GKO}} \mathrm{CD} 4^{+} \mathrm{CD} 44^{+} \mathrm{T}$ cells in DLN and SC, demonstrating that $T_{G K O}$ cells retained the capacity to acquire effector functions (Figure S1A-B).

In contrast to $\mathrm{T}_{\mathrm{GKO}}$ mice, mice with $\mathrm{T}$ cell-specific ablation of Rora $\left(C D 4^{\mathrm{Cre}} \operatorname{Rora}^{\mathrm{flff}}\left(\mathrm{T}_{\mathrm{AKO}}\right)\right)$ readily developed EAE (Figure 1D); however, disease severity was substantially milder than in control, littermate $C D 4^{\text {Cre }}$ Rora wt $\left(\mathrm{T}_{\mathrm{WT}}\right)$ animals (Figures $1 \mathrm{E}$ and $\left.1 \mathrm{~F}\right)$. To probe the intrinsic role of ROR $\alpha$ in pathogenic Th17 cell differentiation, we employed a 1:1 mixed bone marrow chimera strategy similar to that described above (Figures $1 \mathrm{G}$ and S1C). Notably, each donor strain also harbored an $/ 117 a^{e G F P}$ reporter allele, in order to facilitate examination of myelinspecific Th17 cells using MOG-specific MHC class II (I-A $\left.-\mathrm{MOG}_{38-49}\right)$ tetramers (MOG-tet) (Figures $1 \mathrm{G}$ and S1D). Assessment in the DLN at the peak of EAE revealed a modest role for ROR $\alpha$ in the differentiation of pathogenic Th17 cells, with an almost 2-fold reduction in the frequency of CD45.2/2 $\mathrm{T}_{\text {AKo }}$ effector Th17 (Foxp3 ${ }^{\text {neg }}{ }^{\mathrm{ROR}} \gamma \mathrm{t}^{+} \mathrm{CD} 4^{+}$) cells relative to CD45.1/2 $\mathrm{T}_{\mathrm{WT}}$ counterparts (Figures $1 \mathrm{H}$ and S1D). By contrast, the proportions of T-effector cells that exclusively expressed the Th1 lineage transcription factor, T-bet, or the regulatory T cell (Treg) lineage transcription factor, FoxP3, were roughly equivalent between the $\mathrm{T}_{\mathrm{AKO}}$ and $\mathrm{T}_{\mathrm{WT}}$ populations (Figures $1 \mathrm{H}$ and S1D). Strikingly, further skewing (8.2-fold reduction) of the $\mathrm{T}_{\mathrm{AKO}}$ population relative to wild-type cells was observed among ROR $\gamma \mathrm{t}^{+} \mathrm{Th} 17$ cells in the SC (Figures 1 and S1E). Nevertheless, incorporation of the nucleoside analog EdU indicated that differentiating ROR $\gamma \mathrm{t}^{+}$Th17 $\mathrm{T}_{\mathrm{AKO}}$ effector cells proliferated similarly to their $\mathrm{T}_{\mathrm{WT}}$ counterparts during the preclinical stage of disease (Figure S1F). Moreover, expression of the S-phase 
nuclear antigen, Ki67, remained similar in $\mathrm{T}_{\mathrm{AKO}}$ and $\mathrm{T}_{\mathrm{WT}}-\mathrm{Th} 17$ cells located in both the DLNs and SC throughout clinical stages of disease, suggesting that $\mathrm{ROR} \alpha$ does not regulate accumulation of Th17 cells in the SC via proliferation (Figures S1G and S1H). In concert with their lack of accumulation, MOG-tet ${ }^{+}$Th17 $\mathrm{T}_{\text {AKO }}$ cells also exhibited signs of functional impairment in the SC, but not in the DLN, including reduction in proportion of cells expressing the $/ 117 a^{G F P}$ reporter and consistent decrease in the mean fluorescence intensity of ROR $\gamma$ t expression (Figures $1 \mathrm{~J}$ and 1K). These data suggest that while ROR $\alpha$ is unable to mediate strong Th17 pathogenicity in the absence of ROR $\gamma t$ expression, it maintains a prominent role in the regulation of the Th17 effector program.

\section{ROR $\alpha$ is required for a sustained mucosal Th17 response}

To address whether the role of ROR $\alpha$ in Th17 responses can be generalized, we orally vaccinated co-housed littermate $\mathrm{T}_{\mathrm{WT}}$ and $\mathrm{T}_{\mathrm{AKO}}$ mice with an attenuated double mutant (R192G/L211A) form of the heat-labile enterotoxin (dmLT) of enterotoxigenic Escherichia coli, which induces a robust antigen-specific mucosal Th17 response (Fonseca et al., 2015; Hall et al., 2008) (Figure 2A). Following two rounds of vaccination, dmLT-specific (I-A ${ }^{\mathrm{b}}-\mathrm{dmL} \mathrm{T}_{166-174}$ tetramer positive) cells were readily detectable in the small intestinal lamina propria (SILP) of $\mathrm{T}_{\mathrm{WT}}$ and $\mathrm{T}_{\text {AKO }}$ mice (Figure S2A). Yet, both the proportion and number of the dmLT-specific Th17 cells were significantly reduced in $\mathrm{T}_{\mathrm{AKO}}$ mice (Figures $2 \mathrm{~B}, 2 \mathrm{C}$ and $\mathrm{S} 2 \mathrm{~B}$ ). Although this reduction was accompanied by a significant concomitant increase in the frequency of dmLTspecific Th1 cells within the SILP of $\mathrm{T}_{\text {AKO }}$ mice, both mutant and wildtype counterparts harbored similar numbers of dmLT-Th1 cells, suggesting that only the Th17 component of the effector Tcell response was impaired (Figures 2B, 2C and S2B). Amongst the dmLT-specific Th17 cells, the level of ROR $\gamma$ t expression, as well as the frequency of ROR $\gamma \mathrm{t}^{+}$cells that expressed CCR6, a ROR $\gamma$ t-dependent chemokine receptor, were also significantly reduced in $\mathrm{T}_{\mathrm{AKO}}$ cells, reinforcing 
the notion that both $\mathrm{ROR} \alpha$ and $\mathrm{ROR} \gamma \mathrm{t}$ are required to program and maintain optimal Th17 function (Figures 2D, 2E, S2C and S2D).

We additionally examined the role of ROR $\alpha$ in the differentiation and maintenance of ileal homeostatic Th17 cells induced by segmented filamentous bacteria (SFB). This system allows for study of temporal regulation of Th17 cell differentiation, beginning with priming and proliferation in the draining mesenteric lymph node (MLN) and continuing with expansion and cytokine production in the lamina propria (Sano et al., 2015). TWT- or $\mathrm{T}_{\text {AKO }}$ mice were backcrossed with transgenic mice expressing a TCR (7B8tg) specific for a dominant epitope of SFB (Yang et al., 2014). Naïve 7B8tg T cells from these animals were labeled with Cell Trace Violet (CTV) and adoptively transferred into isotype-distinct hosts colonized with SFB (Figure $2 \mathrm{~F})$. Assessment of donor-derived T cells in the intestine-draining MLN revealed that CTV dilution and ROR $\gamma$ t induction were similar between $T_{W T}$ and $T_{A K O}$ 7B8tg cells (Figures 2G-J), consistent with the notion that ROR $\alpha$ is dispensable for commitment to the Th17 program. Accordingly, similar numbers of $\mathrm{T}_{\mathrm{AKO}}$ and $\mathrm{T}_{\mathrm{WT}}$ 7B8tg $\mathrm{T}$ cells were recovered two-weeks posttransfer from the terminal ileum section of the SILP, where SFB resides (Figure 2K). However, based on ROR $\gamma$ t expression, there was a significant decrease in the proportion and total number of Th17 cells among $\mathrm{T}_{\mathrm{AKO}}$ compared to $\mathrm{T}_{\mathrm{WT}} 7 \mathrm{~B} 8 \mathrm{tg} \mathrm{T}$ cells (Figures $2 \mathrm{~L}, 2 \mathrm{M}$ and S2E), and the ROR $\gamma \mathrm{t}$ MFI was also reduced in the mutant T cells (Figure $2 \mathrm{~N}$ and S2F). Altogether, our results indicate that $\mathrm{ROR} \alpha$ confers the ability of $\mathrm{T}$ helper cells to mount a sustained Th17 cell response in target tissues.

\section{$R O R \alpha$ is required for maintenance of the pathogenic Th17 program in the central nervous system}

To investigate the molecular mechanism by which ROR $\alpha$ regulates the Th17 program, Twt and $\mathrm{T}_{\text {AKO }}$ Th17 cells were isolated from the DLN and SC of 3 separate cohorts of mixed chimeric 
mice based on their IL17A ${ }^{\text {eGFP }}$ expression (see Figure $1 \mathrm{G}$ ) at the peak of EAE disease, and their transcriptomes were sequenced (RNA-Seq)(Figures S3A-C). Based on the number of differentially expressed (DE) genes, Rora deficiency impacted the Th17 program more profoundly in the SC than in the DLN. At a false discovery rate of $1 \%$, there were $33 \mathrm{DE}$ genes in the DLN, but 845 genes in the SC (Figures 3A, S3B and S3C). The most saliently affected gene in both differentiating (DLN) and effector (SC) TAKO-Th17 cells, Bhlhe40, was previously found to be required in both Th1 and Th17 cells for manifestation of EAE (Lin et al., 2016). $\mathrm{T}_{\mathrm{AKO}}$-Th17 cells from the SC also exhibited significant reductions in transcripts encoding proteins that are prominent cell-intrinsic drivers of autoimmune pathogenesis, including Csf2 (Codarri et al., 2011; El-Behi et al., 2011), I/1r1 (Shouval et al., 2016), and I/23r (Abdollahi et al., 2016; Duerr et al., 2006; Gaffen et al., 2014; Hue et al., 2006) (Figure 3B). Indicative of the sweeping effect that loss of ROR $\alpha$ engendered on gene expression at the site of disease, Rorc, which encodes ROR $\gamma$ t, was markedly reduced in $\mathrm{T}_{\mathrm{AKO}}-\mathrm{Th} 17$ cells from the SC, but not from DLN, consistent with reduced expression of direct ROR $\gamma$ t target genes (Figure 3C). Thus, combined with the consistent, albeit modest, reduction in protein expression of ROR $\gamma t$ in $\mathrm{T}_{A K O}$ Th17 cells at effector sites, including the SC and SILP (Figures $1 \mathrm{~K}, 2 \mathrm{D}$ and $2 \mathrm{~N}$ ), these findings raise the possibility that $\mathrm{ROR} \alpha$ reinforces $\mathrm{ROR} \gamma \mathrm{t}$ expression in effector Th17 cells.

To further explore this hypothesis, we developed a retroviral reconstitution system with T cells from MOG peptide-specific (2D2) TCR transgenic mice bred to ROR $\alpha$-deficient or wild-type mice. $\mathrm{T}_{\text {AKO }} 2 \mathrm{D} 2$ cells were transduced with Rora (yielding $\mathrm{T}_{\mathrm{AKO}}-$ Rora cells) or control $\left(\mathrm{T}_{\mathrm{AKO}}-\right.$ Empty) vectors and were then cultured under Th17 cell differentiation conditions. They were then transferred with an equal number of similarly prepared isotype-marked TWT 2D2 cells transduced with a control vector ( $\left.T_{W T}-E m p t y\right)$ into recipients that were then immunized to induce EAE (Figures 3D). Critically, the in vitro differentiated $\mathrm{T}_{\mathrm{AKO}}-$ Rora, $\mathrm{T}_{\mathrm{AKO}}-\mathrm{Empty}_{\mathrm{g}}$, and $\mathrm{T}_{\mathrm{WT}}-\mathrm{Empty}$ 2D2 cells expressed uniform and equivalent levels of ROR $\gamma$ t prior to adoptive transfer (Figure 
S3D). Yet, recapitulating the endogenous model, the frequency of ROR $\gamma \mathrm{t}^{+}$cells amongst $\mathrm{T}_{\mathrm{AKO}}-$ Empty 2D2 cells in the SC at the peak of disease was markedly reduced relative to that of TWTEmpty 2D2tg cells (Figures 3E, 3F, S3E, and S3F). Gating on the ROR $\gamma \mathrm{t}^{+}$population also revealed a modest, though significant, decline in protein expression intensity, as well as an impaired capacity to produce IL-17A upon mitogenic restimulation (Figures 3G, 3H and S3G). Each of these deficits was reversed in $\mathrm{T}_{\mathrm{AKO}}$-Rora 2D2tg cells, corroborating an essential role for ROR $\alpha$ in maintenance of the Th17 effector program (Figures 3E-H, S3D-G). The pronounced effect of ROR $\alpha$ on Bhlhe40 expression in differentiating and effector Th17 cells suggested that its influence on Th17 stability may act indirectly through BHLHE40, which is a critical regulator of autoreactive T cell pathogenicity (Lin et al., 2016; Lin et al., 2014). However, ectopic expression of BHLHE40, despite rescuing impaired $\mathrm{T}_{\mathrm{AKO}}-2 \mathrm{D} 2$ cell accumulation (Figures $\mathrm{S} 3 \mathrm{H}$ J), failed to restore Th17 cell numbers or effector functions among 2D2-TAKo cells (Figures 3I-L and S3K). Thus, regulation of BHLHE40 by ROR $\alpha$ is not sufficient to direct effector Th17 cell maintenance, suggesting that $\mathrm{ROR} \alpha$ regulates other genes that are essential for this differentiation program.

\section{ROR $\alpha$ shares genomic binding sites with ROR $\gamma \mathrm{t}$}

To ascertain whether ROR $\alpha$ directly regulates Th17 lineage maintenance, ChIP-Seq of ROR $\alpha$ was performed with in vitro differentiated Th17 cells generated from ROR $\alpha$-Twin Strep (RORATS) tag knockin-in mice. These animals, which possess a Twin-Strep tag immediately upstream of the stop codon of the Rora locus, had normal development and immune cell functions, including frequencies of ROR $\alpha$-dependent type2 innate lymphoid cells (ILC2) (Figures S4A and S4B) and induction of both $\mathrm{ROR} \alpha$ and ROR $\gamma$ t during in vitro Th17 cell differentiation on par with WT counterparts (Figures S4C and S4D). Alignment of ROR $\alpha$ ChIP peaks with our previously published ROR $\gamma$ t ChIP-Seq results for in vitro polarized Th17 cells (Ciofani et al., 2012) revealed 
significant overlaps of genome binding loci between $\mathrm{ROR} \alpha$ and $\mathrm{ROR} \gamma \mathrm{t}$, including previously reported genes involved in the "pathogenic" Th17 effector program (e.g., I/17a/f, I/23r and Bhlhe40) (Lee et al., 2012) (Figures 3A, 4A and S4E), and gene ontology analysis of the ROR $\alpha$ direct target genes also revealed a significant enrichment in Th17 effector functions and Th17mediated disease pathogenesis (Figure 4B). Notably, ROR $\alpha$ also binds to intronic regions of Rorc (Figure 4C). To further address the interdependency of ROR $\alpha$ and ROR $\gamma \mathrm{t}$ in binding to target loci, ROR $\alpha$ ChIP-Seq was also conducted on Th17-polarized CD4 ${ }^{+} \mathrm{T}$ cells isolated from RORA-TS mice in which ROR $\gamma$ t activity was abolished (RORA-TS-T GKO). Although loss of ROR $\gamma$ t expectedly impeded Th17 cell differentiation (Figure S4F), both Rora induction and protein expression were comparable between WT and RORA-TS-TGKO cells cultured under Th17 polarizing conditions (Figures S4G and S4H). Nevertheless, the majority of ROR $\alpha$ peaks were ablated upon loss of ROR $\gamma$ (Figures 4A and S4E). In contrast, ROR $\gamma$ t binding was not adversely affected in Th17-polarized cells that reciprocally lacked ROR $\alpha$ (Figure S4I). These findings are concordant with a limited and largely ROR $\gamma$ t-dependent role for ROR $\alpha$ during in vitro Th17-cell differentiation.

\section{The $\operatorname{Rorc}(t)+11 \mathrm{~kb}$ locus is required for ROR $\alpha$-mediated ROR $\mathrm{Rt}$ expression in tissue-} resident Th17 cells.

In support of the hypothesis that ROR $\alpha$ can directly regulate ROR $\gamma$ t expression, ChIP-Seq revealed a significant $R O R \alpha$ peak with an embedded ROR response element (RORE) at $+11 \mathrm{~kb}$ from the Rorc(t) transcriptional start site in Th17 cells generated in vitro (Figure 4C). Alignment with ROR $\gamma$ t ChIP-Seq data demonstrated that both family members bind to this region (Figure 4C). Surprisingly, although the assay for transposase-accessible chromatin sequencing (ATACSeq) indicated that this region remained closed in in vitro-differentiated Th17 cells, it was readily accessible in ex vivo IL-17A ${ }^{+}$Th17 cells sorted from the SILP and both DLNs and SC during 
EAE (Figure 4D). Moreover, comparison of chromatin accessibility in T-helper lineages enriched from PBMC under the ENCODE Project (Maurano et al., 2012) revealed a prominent syntenic DNase Hypersensitivity Site (DHS) at $+10 \mathrm{~kb}$ from the RORC transcription start site (TSS) that was specific to Th17 cells, highlighting that this region constitutes a functionally conserved enhancer in human Type-17 immunity (Figure 4E). Altogether, these data suggest that synergy of $\mathrm{ROR} \alpha$ and $\mathrm{ROR} \gamma \mathrm{t}$ binding to the intronic RORE following early ROR $\gamma$ t induction governs subsequent ROR $\gamma$ t stability in Th17 cells in vivo.

To functionally interrogate the role of the $\operatorname{Rorc}(t)+11 \mathrm{~kb}$ cis-element in vivo, we generated transgenic mice with a Rorc-containing BAC engineered to have a mCherry reporter at the ROR $\gamma t$ translational start site with or without deletion of the $+11 \mathrm{~kb}$ cis-element $(\mathrm{WT} \operatorname{Tg}(\operatorname{Rorc}(\mathrm{t})$ mCherry and $\Delta+11 \mathrm{~kb}$ Rorc(t)-mCherry) (Figure 5A). To serve as an internal control, the transgenic mice were bred to $\operatorname{Rorc}(t)^{\text {GFP }}$ mice containing a GFP reporter knocked into the endogenous Rorc(t) locus (Figure 5A and S5A). Thymocyte development was normal in both WT Tg and $\Delta+11 \mathrm{~kb}$ Tg lines, with mCherry expression highest in double positive and early postselection single positive thymocytes, consistent with known expression patterns of ROR $\gamma \mathrm{t}$ (He et al., 2000; Sun et al., 2000) (Figure S5B). Within the SILP, a strong correlation between GFP and mCherry expression was also observed in both innate and adaptive Type-17 lymphocytes, which included not only Th17 cells, but also $\gamma \delta$ T cells and type 3 innate lymphoid cells (ILC3) of WT Tg mice (Figure 5B, 5C and S5C-E). In stark contrast, mCherry activity within the SILP of $\Delta+11 \mathrm{~kb}$ Tg mice was lost in each of these populations, suggesting that the $+11 \mathrm{~kb}$ cis-element is a bona fide enhancer for all Type-17 lymphocyte lineages in vivo (Figure 5B, 5C and S5C-E). Nevertheless, CD4 ${ }^{+} \mathrm{T}$ cells isolated from $\Delta+11 \mathrm{~kb} \mathrm{Tg}$ mice readily expressed mCherry upon in vitro Th17 polarization (Figure 5D and 5E). This finding, together with the chromatin accessibility data for in vitro polarized Th17 cells (Figure 4D), as illustrated by failure to open chromatin at the $+11 \mathrm{~kb}$ locus, suggests that the $+11 \mathrm{~kb}$ cis-element is an essential enhancer for the Type- 17 
lymphocytes in vivo but is dispensable for thymocyte development and in vitro Th17 cell differentiation.

To further investigate whether the $+11 \mathrm{~kb}$ conserved noncoding sequence functions via the binding of ROR family TFs in EAE, an optimized Cas9/gRNA RNP transfection approach was utilized to mutate the RORE and preclude ROR $\alpha$ and $\mathrm{ROR} \gamma \mathrm{t}$ binding to the $+11 \mathrm{~kb}$-enhancer in in vitro-differentiated Th17 cells (Figure 6A). Targeting the locus in activated naïve 2D2tg-T cells resulted in nearly $100 \%$ editing efficiency, with both indels and deletions that did not exceed 100bps (Figures S5A and S5B). Following in vitro Th17 cell polarization with IL-6, TGF- $\beta$ and IL23, control gene (sgCtrl) and $+11 \mathrm{~kb}$-enhancer-targeted $\left(+11 \mathrm{~kb}^{\triangle \mathrm{RORE}}\right) 2 \mathrm{D} 2 \mathrm{tg}-\mathrm{Th} 17$ cells were adoptively transferred into wild-type recipients, which were then immunized with MOG peptide to trigger EAE (Figure $6 \mathrm{~A}$ ). Consistent with the inaccessibility the Rorc $+11 \mathrm{~kb}$ site in in vitro polarized Th17 cells, neither the induction of ROR $\gamma$ t, nor the capacity to secrete IL-17A, were affected in the $+11 \mathrm{~kb}^{\triangle \mathrm{RORE}} 2 \mathrm{D} 2 \mathrm{tg}-\mathrm{Th} 17$ cells at the time of transfer (Figures 6B and 6C). However, by the peak of disease, in comparison to control-targeted counterparts, both the percentage and absolute number of ROR $\gamma \mathrm{t}^{+}+11 \mathrm{~kb}^{\triangle \mathrm{RORE}} 2 \mathrm{D} 2 \mathrm{tg}-\mathrm{Th} 17$ cells recovered from the SC sharply declined (Figures 6D-F). Among the residual Th17 cells, ROR $\gamma$ t expression levels were also significantly reduced (Figure 6G). These findings reflect the compromised stability of RORyt in $\mathrm{T}_{\text {AKO }}$ 2D2tg-Th17 cells during EAE (Figures 3E-H). Accordingly, ectopic overexpression of Rora restored ROR $\gamma$ t expression in $\mathrm{T}_{\text {AKO }}$ 2D2tg-Th17 cells, but not in $\mathrm{T}_{\mathrm{AKO}}$ $+11 \mathrm{~kb}^{\triangle \mathrm{RORE}} 2 \mathrm{D} 2 \mathrm{tg}-\mathrm{Th} 17$ cells (Figures $6 \mathrm{H}$ and $6 \mathrm{I}$ ), consistent with ROR $\alpha$ binding to the $+11 \mathrm{~kb}$ enhancer mediating sustained expression of RORyt. Thus, our findings uncover a novel enhancer required for maintenance of the Th17 cell program in tissues and regulated, at least in part, by ROR $\alpha$.

\section{Discussion}




\section{Regulation of the Th17 program by ROR $\alpha$ and ROR $\gamma t$}

Our current study confirms that both ROR $\alpha$ and ROR $\gamma$ t play important roles in orchestrating

Th17 lineage maintenance. Our data suggest that ROR $\alpha$ and ROR $\gamma$ t may regulate the expression of Th17-associated genes through binding to the same ROREs with their highly similar DNA-binding domains (Cook et al., 2015). This implies that the individual expression levels of ROR $\alpha$ and ROR $\gamma$ t might be limiting in T cells, leaving ROREs unoccupied, and that expression of both nuclear receptors is required to saturate RORE binding sites and drive maximal ROR-responsive gene expression. Nevertheless, we also observed that expression of ROR $\gamma$ t is a prerequisite for ROR $\alpha$ binding to the shared RORE. In the absence of ROR $\gamma$ t, the TGKO Th17 cells lost most of the genome-wide binding of ROR $\alpha$ at the shared target sites. Considering that $\mathrm{ROR} \alpha$ expression was not impaired upon ROR $\gamma$ t deletion, these data are consistent with the model previously proposed by Ciofani et. al, in which ROR $\gamma \mathrm{t}$ serves as a master switch for Th17 differentiation and creates a feedback pathway that, in turn, stabilizes Th17 commitment (Ciofani et al., 2012). Indeed, we observed that heterozygous loss of ROR $\gamma \mathrm{t}$ expression impaired optimal in vivo Th17 cell differentiation (Pokrovskii, 2018).

Another possible scenario is that ROR $\alpha$ and ROR $\gamma$ t may bind to DNA cooperatively. Like all nuclear receptors, ROR proteins have been shown to bind cognate DNA elements as monomers or dimers: as monomers to ROREs containing a single consensus half site (PuGGTCA) immediately preceded by a short A/T-rich region, and as dimers to tandem half sites oriented as palindromes, inverted palindromes, or direct repeats (Giguere, 1999). Indeed, ROR $\alpha: R O R \gamma t$ heterodimers could possess distinct functional activity compared to monomers or homodimers because of their unique N-terminal trans-activation domains (NTDs) (Giguere, 1999; McBroom et al., 1995). Yet, the precise hierarchical roles of ROR $\alpha$ and ROR $\gamma \mathrm{t}$ in Th17 differentiation and function are unclear and need to be further elucidated. 


\section{Diverse immune functions of ROR $\alpha$}

Although our in vivo studies indicate a Th17-specific role of ROR $\alpha$ during mucosal immune responses to SFB and oral vaccination, as well as in Th17-mediated EAE pathogenesis, ROR $\alpha$ has also been found to have important roles in other immune cell types that function in different contexts. ROR $\alpha$ is known to be important for development of type 2 innate lymphoid cells (ILC2) (Halim et al., 2012) and for cytokine production by ILC3 (Lo et al., 2019; Lo et al., 2016). In the liver, ROR $\alpha$ controls inflammation by promoting macrophage M2 polarization (Han et al., 2017; Kopmels et al., 1992). Among other T cell lineages, it was also shown to have an important function in skin Tregs, where it is required for proper regulation of the immune response in atopic dermatitis (Malhotra et al., 2018). A recent study showed that ROR $\alpha$ is involved in mounting Th2 responses during worm infections and allergy (Haim-Vilmovsky,et al., 2019). $\mathrm{ROR} \alpha$ thus has wide-ranging activities in the regulation of immune responses. Mechanisms by which ROR $\alpha$ differentially regulates transcription in these diverse cell types in vivo under various immune-contexts remain poorly understood. Furthermore, it is not clear what direct target genes ROR $\alpha$ controls in non-Type17 cells that lack ROR $\gamma$ t expression. To elucidate the context-dependent, cell type-, and tissue-specific targets of ROR $\alpha$ in small numbers of ex vivo isolated cells, new and more sensitive technologies will be needed to identify with base-pair precision the regions of DNA that it occupies.

\section{ROR $\alpha$ as a potential drug target for Th17-mediated chronic inflammatory conditions}

Chronic inflammation underlies a number of debilitating human diseases including inflammatory bowel disease, multiple sclerosis, psoriasis, and various arthritides (Bamias et al., 2016;

Firestein and Mclnnes, 2017; Netea et al., 2017; Noda et al., 2015). Th17 cells have central roles in many of these diseases. The transcription factor ROR $\gamma \mathrm{t}$ was initially coined the master regulator of the Th17 program, but targeting ROR $\gamma$ t therapeutically is dangerous owing to an 
enhanced risk of thymoma upon its inhibition (Guntermann et al., 2017; Guo et al., 2016;

Liljevald et al., 2016). ROR $\alpha$ was also implicated in Th17 functions (Castro et al., 2017; Yang et

al., 2008), but its precise role and relationship to ROR $\gamma$ function were not investigated.

Exploration of the divergent effects of ROR $\alpha$ and ROR $\gamma$ t in Th17-elicited autoimmune

pathogenesis revealed that ROR $\alpha$ is crucial for the functional maintenance of the Th17 program

at the site of inflammation despite exerting a relatively minor influence during differentiation in the lymph nodes. During EAE, Th17 cells devoid of ROR $\alpha$ are limited in their accumulation in the central nervous system, and those that are present display a dampened pathogenic program. Probing the intersection of ROR binding targets identified by ChIP-Seq with RNA-Seq data obtained from ex vivo isolated ROR $\alpha$-deficient Th17 cells indicated that the majority of $\mathrm{ROR} \alpha$ targets are shared with ROR $\gamma$ t. Among the most significant were the IL-23 receptor, II23r, and the transcription factor Bhlhe40, which are critical for driving Th17 pathogenesis by way of inflammatory T cells having shared Th17 and Th1 features (Harbour et al., 2015; Hirota et al., 2011). Strikingly, ROR $\alpha$ was also found bound to a conserved cis-regulatory enhancer element in the Rorc locus that is crucial for maintenance of ROR $\gamma$ t expression in effector Th17 cells in vivo. Intriguingly, using our laboratory's previous transcription factor binding data (Ciofani et al., 2012), Chang et al. recently identified this region (CNS11) in their study of Th17 enhancers, but did not prosecute its function owing to its lack of H3K27Ac marks and weak interaction with p300 (Chang et al., 2020). These data are also consistent with the marginal chromatin accessibility of the $+11 \mathrm{~kb}$ region observed upon in vitro differentiation and suggests that a heretofore unidentified factor mediates in vivo accessibility of this region. Together, these findings indicate that ROR $\alpha$ not only regulates the Th17 program by a means parallel to ROR $\gamma \mathrm{t}$, but that it may serve a particularly prominent in vivo function by dynamically reinforcing ROR $\gamma \mathrm{t}$ expression in the absence of saturating levels of active ROR $\gamma \mathrm{t}$. 
Natural ligands and synthetic compounds that modulate the function of nuclear receptors have demonstrated tremendous therapeutic potential for multiple clinical conditions (Cheng et al., 2019; Huh et al., 2011; Kojetin and Burris, 2014; Marciano et al., 2014; Moutinho et al., 2019). Our current study, by identifying $R O R \alpha$ as a key regulator of the sustained Th17 effector program, suggests that targeting this receptor could be a viable strategy for treating autoimmune pathologies linked to Th17 effector functions in chronically inflamed patient tissues. Furthermore, the involvement of ROR $\alpha$ in ILC2 development (Halim et al., 2012; Wong et al., 2012) and Type-2 immune functions (Haim-Vilmovsky,et al., 2019) may provide additional therapeutic opportunities for diseases such as asthma, chronic obstructive pulmonary disease (COPD), and idiopathic pulmonary fibrosis (Gieseck et al., 2018).

However, like other ROR family members, ROR $\alpha$ regulates multiple non-immune cell types, in non-inflammatory contexts. For example, staggerer mice, which carry a spontaneous deletion in Rora, have an underdeveloped cerebellar cortex, with deficiency in granule and Purkinje cells (Gold et al., 2007). ROR $\alpha$ has also been linked to neurologic disorders, including autism, in humans (Devanna and Vernes, 2014; Nguyen et al., 2010; Sarachana and Hu, 2013). Significant circadian disruption, described in autistic patients (Hu et al., 2009; Melke et al., 2008; Nicholas et al., 2007), may be related to the role of ROR $\alpha$ in regulation of the circadian clock (Jetten, 2009; Kojetin and Burris, 2014). Therefore, a deeper understanding of cell type-specific and context-dependent regulation of ROR $\alpha$ is likely needed to inform strategies to combat ROR $\alpha$-associated immune diseases.

In summary, our study has elucidated a non-redundant role of ROR $\alpha$ in Th17 lineage maintenance via reinforcement of the ROR $\gamma \mathrm{t}$ transcriptional program. Further characterization of the interaction of these two nuclear receptors may enable more refined strategies to target specific processes that fuel chronic inflammatory disease. 
Acknowledgements: We thank members of the Littman laboratory for valuable discussions,

Sang Y. Kim at the Rodent Genetic Engineering Core (RGEC) of NYU Medical Center

(NYULMC) for generation of RORA-TS mice, Adriana Heguy and the Genome Technology

Center (GTC) for RNA and ChIP sequencing. We also thank Yasmine Belkaid (NIAID), Oliver

Harrison (Benaroya Research Institute) and Timothy Hand (University of Pittsburgh) for

providing the specific MHCII (I-A $\left.\mathrm{A}^{\mathrm{b}}-\mathrm{dmL} \mathrm{T}_{166-174}\right)$ tetramer and for helpful discussions surrounding

the $d m L T$ vaccine data. Lyophilized $d m L T$ was generously provided by Elizabeth Norton at

Tulane University. The GTC and RGEC are partially supported by Cancer Center Support grant

P30CA016087 at the Laura and Isaac Perlmutter Cancer Center. This work was supported by

an HHMI Fellowship of the Damon Runyon Cancer Research Foundation 2232-15 (J.-Y.L.), a

Dale and Betty Frey Fellowship of the Damon Runyon Cancer Research Foundation 2105-12

(J.A.H), the Howard Hughes Medical Institute (D.R.L.), the Helen and Martin Kimmel Center for

Biology and Medicine (D.R.L.), and National Institutes of Health grants R01Al121436 and

R01DK103358 (D.R.L.).

Author Contributions: J.-Y.L., J.A.H, and D.R.L. conceived the project; J.-Y.L. and J.A.H. performed the experiments; M.P. investigated cis-regulatory elements of Rorc(t) locus; L.K. performed bioinformatic analyses; L.W. contributed to antibody generation and purification; J.Y.L., J.A.H, M.P. and D.R.L. wrote the manuscript.

Declaration of Interests: D.R.L. consults for and has equity interest in Chemocentryx, Vedanta, Immunai, and Pfizer, Inc.

\section{Figure Legends}

Figure 1. Divergent roles of ROR $\gamma \mathrm{t}$ and $\mathrm{ROR} \alpha$ in the differentiation and maintenance of pathogenic Th17 cells in autoimmune encephalomyelitis (EAE). 
(A-C) EAE frequency and severity in T cell-specific ROR $\gamma$ t knock-out (T $\mathrm{TKO}_{\mathrm{GK}}$ CD4 ${ }^{\text {Cre }}$ Rorc $^{\text {fl/fl; }}$; $\mathrm{n}=18)$ and WT $\left(C D 4^{\text {Cre. }} ; \mathrm{n}=16\right)$ mice. Time course of EAE incidence $(\mathrm{A})$ and mean daily disease score of symptomatic mice (B); maximum disease score of EAE symptomatic mice (C). Summary of 3 experiments.

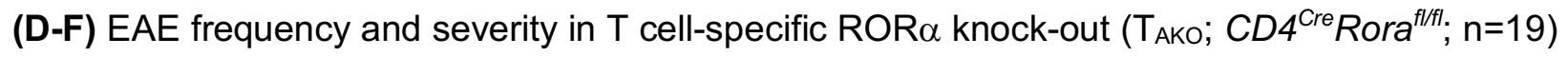
and WT (CD4 $\left.{ }^{\text {Cre }} ; n=19\right)$, as in (A-C). Time course of EAE incidence (D) and mean daily disease score of symptomatic mice (E); maximum disease score of EAE symptomatic mice $(\mathbf{F})$. Summary of 3 experiments.

(G) Schematic of EAE induction in CD45.1/2 $\mathrm{T}_{\mathrm{WT}}$ and CD45.2/2 $\mathrm{T}_{\text {AKO }} 50: 50\left(\mathrm{~T}_{\mathrm{WT}} / \mathrm{T}_{\text {AKO }}\right)$ mixed bone marrow (BM) chimeras.

(H and I) Percent of $\mathrm{T}_{\mathrm{WT}}$ and $\mathrm{T}_{\mathrm{AKO}}$ cells of the indicated T cell phenotypes among MOGtetramer ${ }^{+} \mathrm{CD}^{+} \mathrm{T}$ cells from draining lymph node $(\mathrm{DLN} ; \mathbf{H})$ or spinal cord $(\mathrm{SC} ; \mathrm{I})$ of $\mathrm{T}_{W T} / \mathrm{T}_{\mathrm{AKO}} \mathrm{BM}$ chimera at peak of EAE. Each phenotypic program was determined by the specific transcription factor expression by FACS (Th17: ROR $\gamma t^{+}$FoxP $3{ }^{\text {Neg }}$ CD $44^{\text {hi }}{ }^{\text {CD }} 4{ }^{+}$T cells, Th1: T-Bet ${ }^{+}$ROR t $^{\text {Neg }}$ FoxP3 ${ }^{\text {Neg }} \mathrm{CD}_{4} 4^{\text {hi }} \mathrm{CD}^{+}{ }^{\mathrm{T}}$ cells, Treg: FoxP3 ${ }^{+} \mathrm{CD} 44^{\mathrm{hi}} \mathrm{CD} 4^{+} \mathrm{T}$ cells).

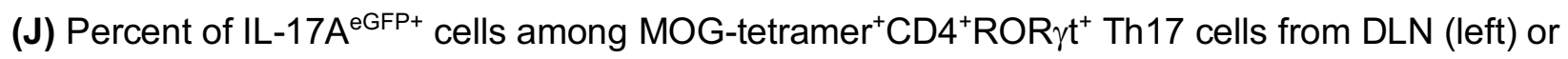
$\mathrm{SC}$ (right) of $\mathrm{T}_{\mathrm{WT}} / \mathrm{T}_{\mathrm{AKO}} \mathrm{BM}$ chimera at peak of $\mathrm{EAE}$.

(K) ROR $\gamma \mathrm{t} \mathrm{gMFI} \mathrm{(geometric} \mathrm{mean} \mathrm{fluorescence} \mathrm{intensity)} \mathrm{level} \mathrm{of} \mathrm{MOG-tetramer}{ }^{+} \mathrm{CD} 4^{+} \mathrm{ROR} \gamma \mathrm{t}^{+}$ Th17 cells from DLN (left) or SC (right) of $\mathrm{T}_{\mathrm{WT}} / \mathrm{T}_{\mathrm{AKO}} \mathrm{BM}$ chimera at peak of EAE.

(A and D) Statistics were calculated by log-rank test using the Mantal-Cox method.

(B and E) Statistics were calculated using the two-stage step-up method of Benjamini, Krieger and Yekutieliun. Error bars denote the mean \pm s.e.m.

( $\mathrm{C}$ and $\mathrm{F}$ ) Statistics were calculated using the unpaired sample $\mathrm{T}$ test. Error bars denote the mean \pm s.e.m. 
(E-I) Statistics were calculated using the paired sample $T$ test. ns $=$ not significant, ${ }^{*} p<0.05,{ }^{* *} p$ $<0.01,{ }^{* *} p<0.001,{ }^{* * *} p<0.0001$.

$(\mathrm{H}-\mathrm{K})$ Data combined from three experiments with $12 \mathrm{BM}$ chimera mice.

See also Figure S1.

Figure 2. ROR $\alpha$ drives sustained mucosal Th17 cell responses.

(A-E) Oral vaccination of littermate $\mathrm{T}_{\mathrm{WT}}$ and $\mathrm{T}_{\mathrm{AKO}}$ mice with an attenuated double mutant (LT R192G/L211A) of the heat-labile enterotoxin of enterotoxigenic Escherichia coli, previously shown to induce a robust Th17 response.

(A) Experimental scheme to examine the role of Rora in mucosal Th17 responses.

(B and $\mathbf{C}$ ) The proportion (B) and absolute number (C) of dmLT-specific Th17 and Th1 cells. Phenotypes were determined by FACS profiles for specific transcription factors (Th17:

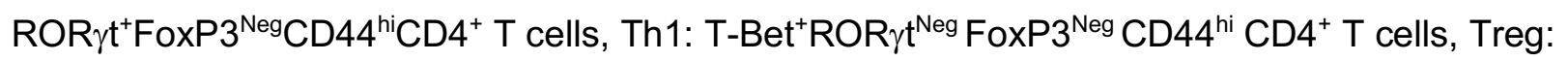
FoxP $3^{+} C D 44^{\text {hi }}{ }^{2} D 4^{+} T$ cells $)$. Data combined from three experiments with $T_{W T}(n=13)$ and $T_{A K O}$ $(n=16)$ littermates.

(D) ROR $\gamma \mathrm{t}$ gMFI of dmLT-specific Th17 cells.

(E) Percentage of dmLT-specific Th17 cells expressing CCR6.

(F-N) ROR $\alpha$ deficiency impairs SFB-specific Th17 cell accumulation in SILP.

(F) Experimental scheme to examine SFB-specific Th17 cell differentiation and effector function of 7B8tg $T_{W T}$ and $T_{A K O}$ in SFB-colonized hosts.

(G-J) Characterization of donor-derived TWT $(n=9)$ and $T_{A K O}(n=9)$ 7B8tg cells in recipients' mesenteric lymph nodes (MLN) at 4 days post-adoptive transfer. Flow cytometric analysis of

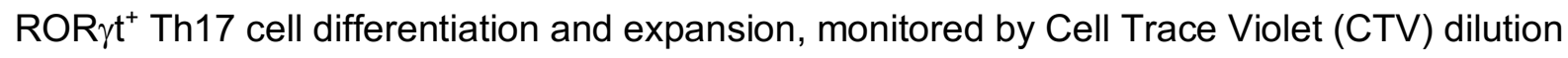
(G), and frequency (H), absolute number (I) and ROR $\gamma$ t gMFI level (J) of ROR $\gamma$ t-expressing 7B8tg cells. Data combined from two experiments. 
(K-N) Characterization of donor-derived $T_{W T}(n=16)$ and $T_{A K O}(n=18) 7 B 8 t g$ cells in recipients' SILPs at 2 weeks post adoptive transfer. Summary of the total numbers (K) of SILP. accumulated 7B8tg cells, and frequency (L), absolute number (M) and ROR $\gamma \mathrm{t}$ gMFI level (N) of ROR $\gamma$ t expressing 7B8tg cells. Data combined from three experiments.

Statistics were calculated using the unpaired sample $T$ test. Error bars denote the mean \pm s.e.m. ns $=$ not significant, ${ }^{*} p<0.05,{ }^{* * *} p<0.001,{ }^{* * * *} p<0.0001$.

See also Figure S2.

\section{Figure 3. ROR $\alpha$ stabilizes the Th17 transcriptional program in effector tissues}

(A-C) RNA-Seq result of $T_{W T}$ and $T_{A K O}$ Th17 cells, isolated as IL17A ${ }^{\text {eGFP }}$-expressing T cells from the DLN and SC of 3 separate cohorts of mixed BM chimera mice at peak of EAE.

(A) Volcano plot depicting differentially expressed (DE) genes of $T_{W T}$ versus $T_{\text {AKO }}$ IL17A ${ }^{\text {eGFP+ }}$ Th17 cells from the SC. Black dots are significant DE genes. DE genes were calculated in DESeq2 using the Wald test with Benjamini-Hochberg correction to determine the false discovery rate $(F D R<0.01)$. Purple dots highlight genes that include ROR $\alpha$ ChIP-Seq peaks within $10 \mathrm{~kb}$ of the gene body.

(B and C) Normalized counts of autoimmune disease-associated (I/1r1, I/23r, Bh/he40), pathogenic (Csf2) genes (B) and Rorc (C) in $\mathrm{T}_{\mathrm{WT}}$ and $\mathrm{T}_{\mathrm{AKO}} / 117 \mathrm{a}^{\mathrm{eGFP+}}$ Th17 cells from the DLN $\left(T_{W T}(n=3)\right.$ and $\left.T_{A K O}(n=3)\right)$ and SC $\left(T_{W T}(n=3)\right.$ and $\left.T_{A K O}(n=2)\right)$ at peak of EAE. Statistics were calculated using the unpaired sample $\mathrm{T}$ test. $\mathrm{ns}=$ not significant, ${ }^{*} \mathrm{p}<0.05,{ }^{* *} \mathrm{p}<0.01$. (D) Experimental scheme to examine the role of ROR $\alpha$ and BHLHE40 in maintenance of the auto-reactive effector Th17 program in inflamed SC during EAE. 2D2tg TWT (CD4 ${ }^{\text {Cre/CD45.1/2) }}$

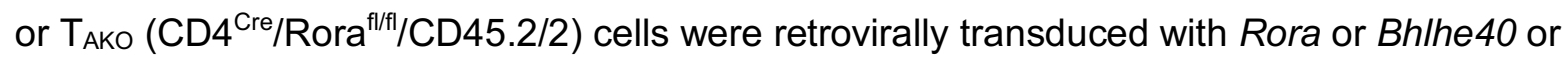
control (Empty) vector, then in vitro polarized to Th17 cells (with IL-6+TGF- $\beta+$ IL-23) for 5 days. 
The polarized $\mathrm{T}_{\mathrm{WT}}$ and $\mathrm{T}_{\mathrm{AKO}} 2 \mathrm{D} 2$ cells were combined 1:1 and transferred into recipients $\left(C D 4{ }^{\text {Cre }} / C D 45.1 / 1\right)$ followed by EAE induction (MOG + CFA + Pertussis toxin immunization).

(E) Flow cytometry analysis of ROR $\gamma$ t and T-bet expression of $\mathrm{T}_{\mathrm{WT}}$, Rora-deficient ( $\mathrm{T}_{\mathrm{AKO}}$-Empty) and Rora-reconstituted ( $\left.\mathrm{T}_{\mathrm{AKO}}-\mathrm{Rora}\right) 2 \mathrm{D} 2$ cells in SC at peak of EAE.

(F and G) Frequency (F) and ROR $\gamma \mathrm{tgMFI}(\mathbf{G})$ of ROR $\gamma \mathrm{t}^{+}$2D2tg cells amongst donor $\mathrm{T}_{\text {AKO- }}$ Empty or $\mathrm{T}_{\mathrm{AKO}}-$ Rora 2D2tg cells compared to the $\mathrm{T}_{\mathrm{WT}}$-Empty in spinal cord at peak of EAE. (H) Frequency of indicated IL-17A-producing donor-derived 2D2tg-Th17 cells in SC at peak of EAE following ex vivo PMA/lonomycin re-stimulation.

(I) Flow cytometry analysis of ROR $\gamma$ t and T-bet expression of $\mathrm{T}_{\mathrm{WT}}-$ Empty and $\mathrm{T}_{\mathrm{AKO}}$-Empty or Bhlhe40 ectopic expressing ( $\mathrm{T}_{\mathrm{AKO}}-\mathrm{Bh}$ he40) cells in spinal cord at peak of EAE.

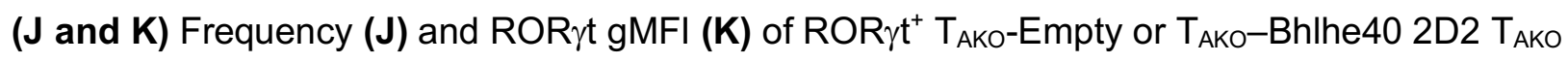
cells compared to TWT $_{W T}$ Empty.

(L) Frequency of indicated IL-17A-producing donor-derived 2D2tg-Th17 cells in SC at peak of EAE following ex vivo PMA/lonomycin re-stimulation.

(E-H) Summary of 2 experiments, with TWT-Empty:T ${ }_{A K O}-E m p t y(n=4)$ and TWT-Empty: $T_{A K O}$-Rora $(n=6)$ recipients. Statistics were calculated using the paired sample T test. ${ }^{*} p<0.05,{ }^{* *} p<$ $0.01,{ }^{* * *} p<0.001,{ }^{* * * *} p<0.0001$.

(I-L) Summary of 2 experiments, with $T_{W T}-E m p t y: T_{A K O}-E m p t y ~(n=7)$ and $T_{W T-E m p t y: T_{A K O}}$ Bhlhe40 $(n=4)$ recipients. Statistics were calculated using the paired sample T test. * $p<0.05$, ${ }^{* *} p<0.01,{ }^{* * *} p<0.001,{ }^{* * *} p<0.0001$

See also Figure S3.

Figure 4. ROR $\alpha$ shares genomic binding sites with ROR $\gamma \mathrm{t}$ in Th17 cells.

(A) ChIP-Seq tracks of ROR $\gamma$ t and ROR $\alpha$ within Th17 effector program genes. 
(B) Gene ontology analysis of ROR $\alpha$ direct target genes (Peak(s) found within 10kb of gene body).

(C) ChIP-Seq data exhibiting ROR $\gamma$ t and ROR $\alpha$ binding to cis-regulatory elements in Rorc locus.

(D) ATAC-Seq data showing open cis-elements in the Rorc locus of in vitro differentiated or ex vivo isolated T cell lineages. Small intestine (SI) or EAE spinal cord (SC) T cells were FACS sorted from $/ / 17 a^{e G F P}$ mice gated on $\mathrm{TCR}^{+}$then either GFP positive or negative.

(E) UCSC genome browser depicting DNase-Seq on human Th17 (UCSC Accession: wgEncodeEH003020) and Th2 (UCSC Accession: wgEncodeEH000491) from the Encode database aligned with GRCh37/hg19 and the Vertebrate Multiz Alignment \& Conservation (100 Species) and HMR Conserved Transcription Factor Binding Sites tracks. RORC locus (left) and zoomed +10kb DHS site (right).

See also Figure S4.

Figure 5. The Rorc $+11 \mathrm{~kb}$ cis-element is required for RORyt expression in Th17 cells in vivo, but is dispensable for in vitro differentiation.

(A) Schematic depicting endogenous and BAC transgene allele in WT Tg (Rorc(t)mCherry);Rorc $(\mathrm{t})^{\text {GFP }}$ control or $+11 \mathrm{~kb}$ enhancer mutant $(\Delta+11 \mathrm{~kb}) \operatorname{Tg}(\Delta+11 \mathrm{~kb} \operatorname{Rorc}(\mathrm{t})-$ mCherry);Rorc(t) ${ }^{\text {GFP }}$ mice.

(B and C) Flow cytometry plots (B) and stacked histogram (C) illustrate Rorc(t)-mCherry reporter expression in in vitro differentiated Th17 cells from WT Tg; Rorc(t) ${ }^{\text {GFP }}$ or $\Delta^{+11 \mathrm{kbTg} ; \text { Rorc }(\mathrm{t})}{ }^{\text {GFP }}$ mice. Geometric mean fluorescence intensities (gMFI) are included in parentheses. Representative data of three experiments.

(D and E) Flow cytometry plots (D and stacked histogram $(E)$ illustrates Rorc(t)-mCherry reporter expression in ex vivo isolated Th17 $\left(\mathrm{TCR} \beta^{+} \mathrm{ROR} \gamma \mathrm{t}^{\mathrm{GFP}+}\right)$ cells from SILP of WT Tg 
(Rorc(t)-mCherry); Rorc(t) ${ }^{\text {GFP }}$ control or $+11 \mathrm{~kb}$ enhancer mutant $(\Delta+11 \mathrm{~kb}) \operatorname{Tg}(\Delta+11 \mathrm{~kb}$ Rorc(t)mCherry); Rorc(t) ${ }^{\text {GFP }}$ mice. gMFIs are included in parentheses. Representative data of three experiments.

See also Figure S5.

Figure 6. ROR $\alpha$ promotes in vivo Th17 stability through a conserved enhancer located in the $+11 \mathrm{~kb}$ region of the $\operatorname{Rorc}(t)$ locus

(A) Experimental scheme to interrogate the role of the Rorc $+11 \mathrm{~kb}$ element in vivo.

(B) Stacked histogram illustrates ROR $\gamma t$ expression in control (sgRNA control; sgCtrl) and Rorc $(t)+11 \mathrm{~kb}$ enhancer mutant (sgRNA that target RORE in $+11 \mathrm{~kb}$ cis-element of Rorc $(t)$; $+11 \mathrm{~kb}^{\triangle \mathrm{RORE}}$ ) in vitro differentiated 2D2tg Th17 cells.

(C) Representative FACS plots displaying IL-17A and IFN $\gamma$ production of in vitro polarized Th17 sgCtrl or $+11 \mathrm{~kb}^{\triangle \mathrm{RORE}} 2 \mathrm{D} 2 \mathrm{tg}$ cells.

(D) Representative flow cytometry analysis of ROR $\gamma$ t and T-bet expression in sgCtrl and $+11 \mathrm{~kb}^{\triangle \mathrm{RORE}}$ donor-derived 2D2tg cells in SC at peak of EAE.

(E-G) Frequency (E), number (F) and ROR $\gamma$ t gMFI (G) of ROR $\gamma$ t-expressing sgCtrl or $+11 \mathrm{~kb}^{\triangle R O R E} 2 \mathrm{D} 2 \mathrm{tg}$ cells in SC at peak of EAE. Summary of 2 experiments, with sgCtrl $(n=10)$ and $+11 \mathrm{~kb}^{\triangle \mathrm{RORE}}(\mathrm{n}=9)$ recipients.

(H and I) Flow cytometry analysis of ROR $\gamma$ t and T-bet expression $(\mathrm{H})$ and frequency of ROR $\gamma \mathrm{t}$ expression (I) in sgCtrl or $+11 \mathrm{~kb}^{\triangle \mathrm{RORE}} \mathrm{T}_{\mathrm{AKO}}$ donor-derived 2D2tg cells, retrovirally reconstituted with Rora or Rorgt, in SC at peak of EAE. Summary of 2 experiments, with TWT-sgCtrl-

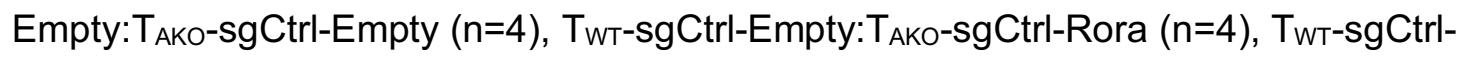
Empty:T ${ }_{A K O}-s g C t r l-R o c(t)(n=4), T_{W T-S g C t r l-E m p t y:} T_{A K O}+11 k^{\triangle R O R E}$-Empty $(n=5), T_{W T-S g C t r l-}$

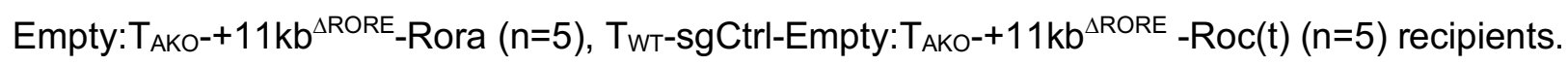


Statistics were calculated using the unpaired sample T test. Error bars denote the mean \pm s.e.m. ns $=$ not significant, ${ }^{*} p<0.05,{ }^{* *} p<0.01,{ }^{* * *} p<0.001,{ }^{* * * *} p<0.0001$

See also Figure S6.

\section{Supplemental figure legends}

Figure S1: Role of ROR $\gamma \mathrm{t}$ and ROR $\alpha$ in Th17 differentiation and accumulation during autoimmune encephalomyelitis, Related to Figure 1

(A and B) IL-17A and IFN $\gamma$ production of CD44 ${ }^{\text {hi }}$ effector T cells upon their ex vivo PMA/lono restimulation. Cells from DLN (A) and $\mathrm{SC}(\mathbf{B})$ of $\mathrm{T}_{\mathrm{WT}} / \mathrm{T}_{\mathrm{GK}} \mathrm{BM}$ chimera at peak of EAE. Data combined three experiments with 13 BM chimera mice.

(C) Mean percent donor-derived $\mathrm{CD} 44^{\mathrm{lo}} \mathrm{CD} 4^{+}$naïve $\mathrm{T}$ cell chimerism at peak of $\mathrm{EAE}$, as determined by flow cytometric analysis of DLN. Data combined three experiments with 12 $\mathrm{T}_{\mathrm{WT}} / \mathrm{T}_{\mathrm{AKO}} \mathrm{BM}$ chimera mice.

(D and E) Gating strategies to identify all Th populations amongst MOG-tetramer ${ }^{+} \mathrm{T}_{\mathrm{WT}}$ and $\mathrm{T}_{\mathrm{AKO}}$ donor-derived CD4 ${ }^{+}$T cells in the DLN (D) and SC (E) of $\mathrm{T}_{\mathrm{WT}} / \mathrm{T}_{\mathrm{AKO}} \mathrm{BM}$ chimera mice at peak of EAE.

(F) Percent of EdU-incorporating Th17 (ROR $\left.\gamma t^{+} F o x P 3^{\text {neg }}\right)$ cells from DLN of $T_{W T} / T_{\text {AKo }} B M$ chimera mice at pre-clinical stage of EAE. Data combined with $13 \mathrm{~T}_{\mathrm{WT}} / \mathrm{T}_{\mathrm{AKO}} \mathrm{BM}$ chimera mice. (G and H) Percent of Ki-67 ${ }^{+}$Th17 (ROR $\gamma t^{+} /$FoxP3 $^{\text {neg }}$ ) cells from DLN (G) and SC (H) of $\mathrm{T}_{W T} / \mathrm{T}_{\text {AKO }}$ BM chimera mice at indicated stages of EAE. Data combined two experiments for the preclinical $(n=4)$, early onset $(n=5)$, acute $(n=9)$, and chronic stages $(n=5)$ of disease, respectively. Statistics were calculated using the paired sample $\mathrm{T}$ test. ns $=$ not significant, ${ }^{*} p<0.05,{ }^{* *} p<$ $0.01,{ }^{* * *} p<0.0001$

Figure S2. ROR $\alpha$ deficiency impairs Th17 cell accumulation in SILP. Related to Figure 2 
(A) Small intestinal lamina propria $\mathrm{CD}^{+} \mathrm{CD} 44^{+} \mathrm{T}$ cells were stained for $\mathrm{I}-\mathrm{A}^{\mathrm{b}} \mathrm{dmLT}$ 166-174 tetramer binding and Foxp3 expression to compare the dmLT-specific CD4 ${ }^{+} \mathrm{T}$ cell effector responses between $\mathrm{T}_{\mathrm{WT}}$ and $\mathrm{T}_{\mathrm{AKO}}$ mice.

(B) Gated dmLT tetramer ${ }^{+} \mathrm{T}$ cells from representative $\mathrm{T}_{\mathrm{WT}}$ (black dot plot) and $\mathrm{T}_{\text {AKO }}$ (red dot plot) SILP were analyzed for expression of T-bet and ROR $\gamma \mathrm{t}$.

(C and D) Histograms depicting expression of ROR $\gamma \mathrm{t}(\mathrm{C})$ and CCR6 (D) in $\mathrm{T}_{\mathrm{WT}}$ and $\mathrm{T}_{\mathrm{AKO}} \mathrm{dmLT}$ tetramer ${ }^{+} \mathrm{ROR} \gamma \mathrm{t}^{+}$Th17 cells. Geometric mean fluorescence intensities (gMFI) are included in parentheses.

(E) Representative flow cytometric analysis of SILP-accumulated $\mathrm{T}_{\mathrm{WT}}$ (black dot plot) and $\mathrm{T}_{\mathrm{AKO}}$ (red dot plot) 7B8tg cells at 2 weeks post adoptive transfer.

(F) Histogram of ROR $\gamma \mathrm{t}$ expression in $\mathrm{T}_{\mathrm{WT}}$ and $\mathrm{T}_{\mathrm{AKO}} \mathrm{ROR} \gamma \mathrm{t}^{+}$7B8 Th17 cells. Geometric mean fluorescence intensities (gMFI) are included in parentheses.

Figure S3. Target genes of ROR $\alpha$, and rescue of EAE phenotype with $\mathrm{T}_{\text {AKo }}$ cells expressing ectopic ROR $\alpha$ or its target gene product Bhlhe40. Related to Figure 3

(A-C) RNA-Seq analysis to identify target genes of ROR $\alpha$. RNA preparation from sorted $1 / 17 a^{\mathrm{eGFP+}}$ mice is described in Methods. One SC $\mathrm{T}_{\text {AKO }}$ Th17 sample contained reads in the deleted region of the Rora locus and thus was excluded from analysis; all other $\mathrm{T}_{\mathrm{AKO}}$ samples were devoid of reads in this region (A). (A) RNA-Seq tracks within Rora locus indicating efficient inducible deletion of Rora (Exon3) of $/ 117 a^{e G F P+} T_{W T}$ and $T_{A K O}$ Th17 cells from DLN and SC of mixed BM chimera mice at peak of EAE. ( $B$ and $C)$ Clustered heatmap of differentially expressed genes between $/ 117 a^{e G F P+}$ Th17 $T_{W T}$ and $T_{A K O}$ cells from DLN (B) and SC (C) of mixed BM chimera mice at peak of EAE. Color scale is based on z-scores for each gene. Genes listed on the righthand margin are color coded. Blue $=$ non-pathogenic Th17 signature. Red $=$ pathogenic Th17 signature. Purple = Genes associated with ROR $\alpha$ ChIP-Seq peaks. 
(D-K) Reconstitution of 2D2 $\mathrm{T}_{\text {AKO }}$ cells with ROR $\alpha$ or Bhlhe40 and phenotypic analysis in spinal cords during EAE. (D) Stacked histogram illustrating representative ROR $\gamma$ t expression of in vitro polarized 2D2tg $\mathrm{T}_{\mathrm{WT}}$-Empty and ROR $\alpha$-deficient ( $\mathrm{T}_{\mathrm{AKO}}$-Empty) or -reconstituted ( $\mathrm{T}_{\mathrm{AKO}}$-Rora) Th17 cells. (E and F) Representative FACS plots $(E)$ and frequency $(F)$ of co-transferred $T_{W T}$ and $\mathrm{T}_{\mathrm{AKO}}$ donor-derived 2D2tg cells, retrovirally reconstituted with or without Rora, in the SC at peak of EAE. (G) Representative FACS plots displaying IL-17A and IFN $\gamma$ production of ROR $\gamma \mathrm{t}^{+}$ Th17 $\mathrm{T}_{\mathrm{AKO}}-$ Empty or $\mathrm{T}_{\mathrm{AKO}}-$ Rora 2D2 cells compared to $\mathrm{T}_{\mathrm{WT}}$-Empty upon ex vivo PMA/lonomycin restimulation. $(\mathrm{H})$ Stacked histogram illustrating representative ROR $\gamma$ t expression of in vitro polarized 2D2tg $\mathrm{T}_{\mathrm{WT}}$-Empty and Rora-deficient ( $\left.\mathrm{T}_{\mathrm{AKO}}-\mathrm{Empty}\right)$ or Bhlhe40-overexpressing ( $\mathrm{T}_{\mathrm{AKO}}$ Bhlhe40) Th17 cells. (I and J) Representative FACS plots (I) and frequencies (J) of cotransferred $\mathrm{T}_{\mathrm{WT}}$ and $\mathrm{T}_{\mathrm{AKO}}$ donor-derived 2D2tg cells, retrovirally transduced with or without Bhlhe 40, in the SC at peak of EAE. (K) Representative FACS plots displaying IL-17A and IFN $\gamma$ production of ROR $\gamma \mathrm{t}^{+}$Th17 $\mathrm{T}_{\mathrm{AKO}}-$-Empty or $\mathrm{T}_{\mathrm{AKO}}-\mathrm{Bh}$ he40 $2 \mathrm{D} 2$ cells compared to $\mathrm{T}_{\mathrm{WT}}$-Empty upon ex vivo PMA/lonomycin re-stimulation.

Data combined from two experiments. Statistics were calculated using the paired sample T test. ns $=$ not significant, ${ }^{*} p<0.05,{ }^{* *} p<0.01,{ }^{* * *} p<0.001,{ }^{* * * *} p<0.0001$.

Figure S4. Shared genomic binding sites of ROR $\alpha$ and ROR $\gamma \mathrm{t}$ in Th17 cells. Related to Figure 4.

(A) Gating strategy to identify innate lymphoid cell (ILC) populations in small intestine lamina propria (SILP) of wild type (WT) and RORA-TS mice. Lineage markers (Lin) include CD3, $\mathrm{TCR} \beta, \mathrm{TCR} \gamma \delta, \mathrm{CD} 11 \mathrm{~b}, \mathrm{CD} 19$.

(B) Absolute number of ILC2 (Lin $\left.{ }^{\text {neg }}, \mathrm{CD} 127^{+}, \mathrm{ROR}_{\gamma} \mathrm{t}^{\text {neg }}, \mathrm{NK} 1.1^{\text {neg }}, \mathrm{KLRG}^{+}, \mathrm{GATA3}^{+}\right)$in SILP of WT and RORA-TS mice. 
(C) Western blot data displaying intact ROR $\alpha$ expression of in vitro polarized RORA-TS Th17 cells.

(D) Stacked histogram illustrates representative ROR $\gamma$ t expression of in vitro polarized RORATS Th17 cells.

(E) Heatmaps depicting genome-wide ROR $\gamma \mathrm{t}$ (left) and ROR $\alpha$-TS (middle and right) ChIP-Seq signals of in vitro polarized Th17 cells, centered on the summit of ROR $\gamma$ t binding sites called on the basis of our earlier dataset (Ciofani et al., 2012). Middle and right alignments compare ROR $\alpha$ occupancy in wild-type and RORyt-deficient T cells.

(F) Representative FACS plots displaying IL-17A and IL-17F production of in vitro polarized TWT or TGKO Th17 cells.

(G) qPCR result of Rora gene expression of in vitro polarized TWT and $T_{\text {GKo }}$ cells cultured under Th0 (IL2) or Th17 (IL-6+TGF- $\beta+$ IL-23) conditions for 48h.

(H) Immunoblots for ROR $\alpha$ and ROR $\gamma$ t of in vitro polarized $T_{W T}$ and $T_{\text {GKO }}$ cells cultured under Th1 (IL-2+IL-12), Treg (IL-2+TGF- $\beta$ ) or Th17 (IL-6+TGF- $\beta+$ IL-23) conditions for 48h. $\beta$-Tubulin is shown as a loading control.

(I) Heatmaps representing ROR $\gamma t$ ChIP-Seq peaks of in vitro polarized $\mathrm{T}_{\mathrm{WT}}$ (left), $\mathrm{T}_{\mathrm{AKO}}$ (middle) and ROR $\alpha /$ ROR $\gamma$ t double knock-out (T⿰KO) (right) Th17 cells.

\section{Figure S5. Requirement of Rorc $(t)+11 \mathrm{~kb}$ cis-element for ROR $\gamma \mathrm{t}$ expression in Type-17}

\section{lymphocytes in vivo. Related to Figure 5.}

(A) Schematic depicting expression of endogenous and Tg reporter alleles in Rorc(t)-mCherry BAC Tg; Rorc $(t)^{G F P}$ mice.

(B) Flow cytometry plots depicting gating strategy to capture thymocyte development from DP $\left(\mathrm{CD} 4^{+} \mathrm{CD} 8^{+}\right)$stage to post-selection stages (left and middle). On the right, mCherry and GFP reporter expression in each color-coded thymocyte subset from indicated $\mathrm{Tg}$ mouse line. 
(C) Flow cytometry of indicated populations from the SILP in WT and $+11 \mathrm{~kb}$ enhancer mutant $\operatorname{Tg}(\Delta+11 \mathrm{kbTg}) ; \operatorname{Rorc}(t)^{G F P}$ mice.

(D and E) mCherry reporter expression of ex vivo isolated ILC3 (Lin ${ }^{\text {neg }}$ ROR $\gamma t^{\text {GFP+ }}$ ) cells (D) and $\gamma \delta \operatorname{Th} 17\left(\gamma \delta \mathrm{TCR}^{+} \mathrm{ROR} \gamma \mathrm{t}^{\mathrm{GFP}+}\right)$ cells $(\mathrm{E})$ from SILP of WT Tg; Rorc $(t)^{\mathrm{GFP}}$ or $\Delta+11 \mathrm{kbTg} ; \operatorname{Rorc}(t)^{\mathrm{GFP}}$ mice. gMFIs are included in parentheses. Representative data of three experiments.

Figure S6. Efficient editing of Rorc $(t)+11 \mathrm{~kb}$ cis-element by CAS9-RNP method. Related to Figure 6.

(A) Analysis of CAS9/gRNA RNP-mediated targeting efficiency of $+11 \mathrm{~kb}$ enhancer by T7 endonuclease I assay.

(B) Sanger sequencing results displaying $\operatorname{Rorc}(t)+11 \mathrm{~kb}$ enhancer mutations and deletions of $\mathrm{T}_{\text {AKO }}+11 \mathrm{~kb} \mathrm{BRORE}^{\mathrm{R}} 2 \mathrm{tg}-\mathrm{Th} 17$ cells.

(C) Experimental scheme to examine the role of $\operatorname{Rorc}(t)+11 \mathrm{~kb}$ cis-element in maintenance of pathogenic Th17 program during EAE.

\section{STAR Methods}

\section{KEY RESOURCE TABLE}

\begin{tabular}{|c|c|c|}
\hline REAGENT or RESOURCE & SOURCE & IDENTIFIER \\
\hline \multicolumn{3}{|l|}{ Antibodies } \\
\hline $\begin{array}{l}\text { Flow Cytometry: anti-mouse CD3 (17A2) } \\
\text { AlexaFluor700 }\end{array}$ & ThermoFisher & Cat. 56-0032 \\
\hline $\begin{array}{l}\text { Flow Cytometry: anti-mouse CD4 (RM4-5) } \\
\text { eFluor450 }\end{array}$ & ThermoFisher & Cat. $48-0042$ \\
\hline $\begin{array}{l}\text { Flow Cytometry: anti-mouse CD11b (M1/70) } \\
\text { PerCP-cy5.5 }\end{array}$ & ThermoFisher & Cat. $45-0112$ \\
\hline $\begin{array}{l}\text { Flow Cytometry: anti-mouse CD11c (N418) } \\
\text { PerCP-cy5.5 }\end{array}$ & ThermoFisher & Cat. $45-0114$ \\
\hline Flow Cytometry: anti-mouse CD14 (Sa2-8) FITC & ThermoFisher & Cat. 11-0141 \\
\hline $\begin{array}{l}\text { Flow Cytometry: anti-mouse CD14 (Sa2-8) PerCP- } \\
\text { cy5.5 }\end{array}$ & ThermoFisher & Cat. $45-0141$ \\
\hline $\begin{array}{l}\text { Flow Cytometry: anti-mouse CD19 (1D3) PerCP- } \\
\text { cy5.5 }\end{array}$ & TONBO & Cat. $65-0193$ \\
\hline Flow Cytometry: anti-mouse CD25 (PC61) PE-Cy7 & TONBO & Cat. $60-0251$ \\
\hline
\end{tabular}




\begin{tabular}{|c|c|c|}
\hline Flow Cytometry: anti-mouse CD44 (IM7) BV500 & BD Bioscience & Cat. 563114 \\
\hline Flow Cytometry: anti-mouse CD45.1 (A20) BV650 & BD Bioscience & Cat. 563754 \\
\hline $\begin{array}{l}\text { Flow Cytometry: anti-mouse CD45.2 (104) APC- } \\
\text { e780 }\end{array}$ & ThermoFisher & Cat. 47-0454 \\
\hline Flow Cytometry: anti-mouse CD62L (MEL-14) APC & ThermoFisher & Cat. A14720 \\
\hline $\begin{array}{l}\text { Flow Cytometry: anti-mouse TCR }(\mathrm{H} 57-597) \\
\text { PerCP-cy5.5 }\end{array}$ & ThermoFisher & Cat. 45-5961 \\
\hline $\begin{array}{l}\text { Flow Cytometry: anti-mouse TCR } \beta \text { (H57-597) } \\
\text { BV711 }\end{array}$ & BD Bioscience & Cat. 563135 \\
\hline $\begin{array}{l}\text { Flow Cytometry: anti-mouse TCR V } \beta 3.2 \text { (RR3-16) } \\
\text { FITC }\end{array}$ & ThermoFisher & Cat. 11-5799 \\
\hline $\begin{array}{l}\text { Flow Cytometry: anti-mouse TCR Vß6 (RR4-7) } \\
\text { FITC }\end{array}$ & BD Bioscience & Cat. 553193 \\
\hline $\begin{array}{l}\text { Flow Cytometry: anti-mouse MHCII (M5/114.15.2) } \\
\text { PE }\end{array}$ & ThermoFisher & Cat. $12-5321$ \\
\hline $\begin{array}{l}\text { Flow Cytometry: anti-mouse MHCII (M5/114.15.2) } \\
\text { PerCP-cy5.5 }\end{array}$ & BD Bioscience & Cat. 562363 \\
\hline $\begin{array}{l}\text { Flow Cytometry: anti-mouse FoxP3 (FJK-16s) } \\
\text { FITC }\end{array}$ & ThermoFisher & Cat. 53-5773 \\
\hline Flow Cytometry: anti-mouse ROR $\gamma \mathrm{t}$ (B2D) PE & ThermoFisher & Cat. 12-6981 \\
\hline $\begin{array}{l}\text { Flow Cytometry: anti-mouse ROR } \gamma \mathrm{t} \text { (Q31-378) } \\
\text { BV421 }\end{array}$ & BD Bioscience & Cat. 562894 \\
\hline $\begin{array}{l}\text { Flow Cytometry: anti-mouse T-bet (eBio4B10) PE- } \\
\text { cy7 }\end{array}$ & ThermoFisher & Cat. 25-5825 \\
\hline $\begin{array}{l}\text { Flow Cytometry: anti-mouse IL-17A (eBio17B7) } \\
\text { eFluor660 }\end{array}$ & ThermoFisher & Cat. 50-7177 \\
\hline $\begin{array}{l}\text { Flow Cytometry: anti-mouse IL-17F (9D3.1C8) } \\
\text { AlexaFluor488 }\end{array}$ & Biolegend & Cat. 517006 \\
\hline $\begin{array}{l}\text { Flow Cytometry: anti-mouse IFN } \gamma(\mathrm{XM} 61.2) \\
\text { eFluor450 }\end{array}$ & ThermoFisher & Cat. 48-7311 \\
\hline In vitro T cell differentiation: anti-hamster IgGs & $\begin{array}{l}\text { MP Biomedicals } \\
\text { Catalog }\end{array}$ & Cat. 55398 \\
\hline $\begin{array}{l}\text { In vitro T cell differentiation: anti-mouse CD3 } \varepsilon \\
(145-2 \mathrm{C} 11)\end{array}$ & BioXCell & Cat. BP0001-1 \\
\hline $\begin{array}{l}\text { In vitro T cell differentiation: anti-mouse CD28 } \\
(37.51)\end{array}$ & BioXCell & Cat. BE0015-1 \\
\hline $\begin{array}{l}\text { In vitro T cell differentiation: anti-mouse IL-4 } \\
\text { (11B11) }\end{array}$ & BioXCell & Cat. BP0045 \\
\hline $\begin{array}{l}\text { In vitro T cell differentiation: anti-mouse IFN } \gamma \\
\text { (XMG1.2) }\end{array}$ & BioXCell & Cat. BP0055 \\
\hline \multicolumn{3}{|l|}{ Biological Samples } \\
\hline Fetal Bovine Serum & Atlanta Biologicals & $\begin{array}{l}\text { Cat. S11195 } \\
\text { Lot. A16003 }\end{array}$ \\
\hline \multicolumn{3}{|l|}{ Chemicals, Peptides, and Recombinant Proteins } \\
\hline EDTA, $0.5 \mathrm{M}, \mathrm{pH} 8.0$ & Ambion & Cat. AM9260G \\
\hline TransIT®-293 Transfection Reagent & Mirus & Cat. MIR2704 \\
\hline Collagenase D & Roche & Cat. 11088882001 \\
\hline
\end{tabular}




\begin{tabular}{|c|c|c|}
\hline Dispase & Worthington & Cat. LS02104 \\
\hline DNase I & Sigma & Cat. DN25 \\
\hline$\overline{\text { DTT }}$ & Sigma & Cat. D9779 \\
\hline Percoll & $\begin{array}{l}\text { GE Healthcare Life } \\
\text { Sciences }\end{array}$ & Cat. 45001747 \\
\hline Ficoll-Paque Premium & $\begin{array}{l}\text { GE Healthcare Life } \\
\text { Sciences }\end{array}$ & Cat. 17-5442-02 \\
\hline 2-Mercaptoethanol (BME) & ThermoFisher & Cat. 21985023 \\
\hline Phorbol Myristate Acetate & Sigma & Cat. P1585 \\
\hline Ionomycin & Sigma & Cat. 10634 \\
\hline Recombinant Human IL-2 & $\begin{array}{l}\text { NIH AIDS Reagent } \\
\text { Program }\end{array}$ & Cat. 136 \\
\hline Recombinant Human TGF $\beta$ Protein & Peprotech & Cat. 100-21-10ug \\
\hline Recombinant Mouse IL-6 Protein & R\&D systems & $\begin{array}{l}\text { Cat. 406-ML- } \\
200 / C F\end{array}$ \\
\hline Recombinant Mouse IL-23 Protein & R\&D systems & Cat. 1887-ML \\
\hline Alt-R® S.p. HiFi Cas9 Nuclease V3 & $\begin{array}{l}\text { Integrated DNA } \\
\text { Technologies }\end{array}$ & $\begin{array}{l}\text { Lot \#0000473804, } \\
0000469029\end{array}$ \\
\hline Alt-R® Cas9 Electroporation Enhancer & $\begin{array}{l}\text { Integrated DNA } \\
\text { Technologies }\end{array}$ & Lot \#0000472336 \\
\hline \multicolumn{3}{|l|}{ Critical Commercial Assays } \\
\hline LIVE/DEAD\& Fixable Blue Dead Cell Stain Kit & ThermoFisher & Cat. L34961 \\
\hline CountBright ${ }^{\mathrm{TM}}$ absolute counting beads & ThermoFisher & Cat. C36950 \\
\hline $\begin{array}{l}\text { BD Cytofix/Cytoperm Plus } \\
\text { Fixation/Permeabilization Solution Kit }\end{array}$ & BD Biosciences & Cat. 554714 \\
\hline $\begin{array}{l}\text { eBioscience }^{\mathrm{TM}} \text { Foxp3 / Transcription Factor } \\
\text { Staining Buffer Set }\end{array}$ & ThermoFisher & Cat. $00-5523-00$ \\
\hline LightCycler® 480 SYBR Green I Master & Roche Life Science & \begin{tabular}{|l} 
Cat. 04707516001 \\
\end{tabular} \\
\hline SuperScript $^{\mathrm{TM}}$ III First-Strand Synthesis System & ThermoFisher & Cat. 18080051 \\
\hline RNeasy Mini Kit & QIAGEN & Cat. 74104 \\
\hline RNeasy MinElute Cleanup Kit & QIAGEN & Cat. 74204 \\
\hline RNase-Free DNase Set & QIAGEN & Cat. 79254 \\
\hline TRIzolTM Reagent & ThermoFisher & Cat. 15596026 \\
\hline BD GolgiPlug Protein Transport Inhibitor & BD Biosciences & Cat. 555029 \\
\hline BD GolgiStop Protein Transport Inhibitor & BD Biosciences & Cat. 554724 \\
\hline EdU Flow Cytometry 647-50 Kit + EdU & Baseclick & $\begin{array}{l}\text { Cat. BCK647-IV- } \\
\text { FC -M }\end{array}$ \\
\hline $\begin{array}{l}\text { CellTrace }{ }^{\mathrm{TM}} \text { Violet Cell Proliferation Kit, for flow } \\
\text { cytometry }\end{array}$ & ThermoFisher & Cat. C34557 \\
\hline 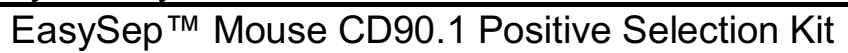 & STEMCELL & Cat. 18958 \\
\hline T7 Endonuclease I & NEB & Cat. M0302 \\
\hline TA Cloning Kits & ThermoFisher & Cat. K202020 \\
\hline DNA SMART TM ChIP-Seq Kit & Takara & Cat. 634865 \\
\hline KAPA HyperPlus Kit & Roche & Cat. 07962380001 \\
\hline Mouse T Cell Nucleofector ${ }^{\mathrm{TM}}$ Medium & Lonza & Cat. VZB-1001 \\
\hline
\end{tabular}




\begin{tabular}{|c|c|c|}
\hline P3 Primary Cell 4D-Nucleofector ${ }^{\mathrm{TM}} \mathrm{X}$ Kit S & Lonza & Cat. V4XP-3032 \\
\hline $\begin{array}{l}\text { truChIP Chromatin Shearing Kit with } \\
\text { Formaldehyde }\end{array}$ & Covaris & Cat. 520154 \\
\hline \multicolumn{3}{|l|}{ Deposited Data } \\
\hline $\begin{array}{l}\text { RNA-Seq raw and analyzed data } \\
\text { : ex vivo RNA-Seq of sort-purified TWT }\left(C D 4^{\text {Cre }} \text { ) or }\right. \\
T_{\text {AKo }}\left(C D 4^{\text {Cre Rora }}{ }^{\text {fl/fl }}\right) \text { Th17 (IL17A }{ }^{\text {eGFP+ }} \text { ) cells from } \\
\text { draining lymph nodes or spinal cords of the mixed } \\
\text { bone marrow chimera mice at the peak of EAE } \\
\text { disease }\end{array}$ & This paper & GEO: GSE163338 \\
\hline $\begin{array}{l}\text { ATAC-Seq raw and analyzed data } \\
\text { : ATAC-Seq analysis of in vitro polarized or ex vivo } \\
\text { sort-purified Th17 cells (IL17A }{ }^{\text {eGFP+ }} \text { ) }\end{array}$ & This paper & GEO: GSE163340 \\
\hline $\begin{array}{l}\text { ChIP-Seq raw and analyzed data } \\
\text { : ROR } \alpha-\text { TwinStrep (TS) ChIP-Seq analysis of in } \\
\text { vitro polarized TWT (ROR } \alpha-T S) \text { or TGKO } \\
\left.\text { (CD4 }{ }^{\text {Cre }} \text { Rorafl/flROR } \alpha-T S\right) \text { Th17 cells }\end{array}$ & This paper & GEO: GSE163339 \\
\hline 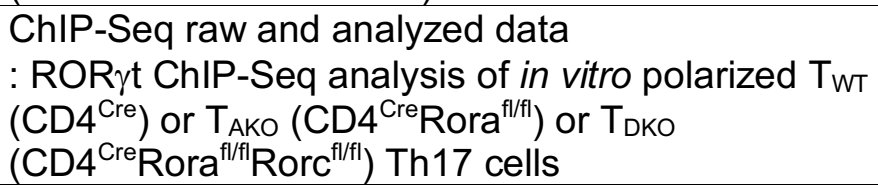 & This paper & GEO: GSE163341 \\
\hline \multicolumn{3}{|l|}{ Experimental Models: Cell Lines } \\
\hline Plat-E Retroviral Packaging Cell Line & Cell Biolabs, INC. & RV-101 \\
\hline \multicolumn{3}{|l|}{ Experimental Models: Organisms/Strains } \\
\hline C57BL/6J & $\begin{array}{l}\text { The Jackson } \\
\text { Laboratory }\end{array}$ & JAX:000664 \\
\hline C57BL/6-II17a $a^{\text {tm1Bcgen }} / J$ & $\begin{array}{l}\text { The Jackson } \\
\text { Laboratory }\end{array}$ & JAX: 018472 \\
\hline B6. SJL Ptprc ${ }^{a}$ Pepc $^{b} /$ BoyJ & $\begin{array}{l}\text { The Jackson } \\
\text { Laboratory }\end{array}$ & JAX:002014 \\
\hline C57BL/6-Tg(Tcra2D2,Tcrb2D2)1Kuch/J & $\begin{array}{l}\text { The Jackson } \\
\text { Laboratory }\end{array}$ & JAX:006912 \\
\hline Tg(Cd4-cre)1Cwi/BfluJ & $\begin{array}{l}\text { The Jackson } \\
\text { Laboratory }\end{array}$ & JAX: 017336 \\
\hline C57BL/6-Tg(Tcra,Tcrb)2Litt/J & $\begin{array}{l}\text { The Jackson } \\
\text { Laboratory }\end{array}$ & JAX: 027230 \\
\hline B6.129S7-Rag1 $1^{\mathrm{tm} 1 \mathrm{Mom} / \mathrm{J}}$ & $\begin{array}{l}\text { The Jackson } \\
\text { Laboratory }\end{array}$ & JAX: 002216 \\
\hline B6(Cg)-Rorc ${ }^{\text {tm3Litt } / J}$ & $\begin{array}{l}\text { The Jackson } \\
\text { Laboratory }\end{array}$ & JAX: 008771 \\
\hline B6J.129S2-Rora ${ }^{\text {tm1.11cs } / I c s ~}$ & $\begin{array}{l}\text { The EMMA mouse } \\
\text { repository }\end{array}$ & EM:12934 \\
\hline RorgtTg(Rorgt-Cherry-CreERT2) & This paper & $\mathrm{N} / \mathrm{A}$ \\
\hline Rorgt $\Delta+11 \mathrm{kbTg}$ (Rorgt-Cherry-CreERT2 $\Delta+11 \mathrm{~kb})$ & This paper & $\mathrm{N} / \mathrm{A}$ \\
\hline
\end{tabular}




\begin{tabular}{|c|c|c|}
\hline B6.129P2(Cg)-Rorc ${ }^{\text {tm2Litt/J }}$ & $\begin{array}{l}\text { The Jackson } \\
\text { Laboratory }\end{array}$ & JAX: 007572 \\
\hline ROR $\alpha$-TwinStrep(TS) & This paper & $\mathrm{N} / \mathrm{A}$ \\
\hline \multicolumn{3}{|l|}{ Oligonucleotides } \\
\hline MSCV-IRES-Thy1.1 DEST & Addgene & Plasmid \#17442 \\
\hline $\begin{array}{l}\text { Control (Olfr2) sgRNA } \\
\mathrm{mA}^{*} \mathrm{mC}^{*} \mathrm{mG}^{*} \mathrm{rArUrUrCrCrUrArArGrArUrGrCrUrUrG} \\
\text { rCrGrUrUrUrUrArGrArGrCrUrArGrArArArUrArGrCr } \\
\text { ArArGrUrUrArArArArUrArArGrGrCrUrArGrUrCrCrG } \\
\text { rUrUrArUrCrArArCrUrUrGrArArArArArGrUrGrGrCr } \\
\text { ArCrCrGrArGrUrCrGrGrUrGrCmU*mU*mU*rU }\end{array}$ & $\begin{array}{l}\text { Integrated DNA } \\
\text { Technologies }\end{array}$ & $\mathrm{N} / \mathrm{A}$ \\
\hline $\begin{array}{l}+11 \mathrm{~kb} \text { targeting sgRNA } \\
\mathrm{mU}^{*} \mathrm{mG}^{*} \mathrm{mG}^{*} \mathrm{rUrGrArGrUrArUrCrUrArGrGrUrCrAr} \\
\text { CrCrGrUrUrUrUrArGrArGrCrUrArGrArArArUrArGr } \\
\text { CrArArGrUrUrArArArArUrArArGrGrCrUrArGrUrCrC } \\
\text { rGrUrUrArUrCrArArCrUrUrGrArArArArArGrUrGrGr } \\
\text { CrArCrCrGrArGrUrCrGrGrUrGrCmU*mU*mU*rU }\end{array}$ & $\begin{array}{l}\text { Integrated DNA } \\
\text { Technologies }\end{array}$ & $\mathrm{N} / \mathrm{A}$ \\
\hline $\begin{array}{l}\text { Rorc_11kb_T7assay forward primer } \\
\text { GTTCTTCTACCCACAGCCCT }\end{array}$ & This Paper & $\mathrm{N} / \mathrm{A}$ \\
\hline $\begin{array}{l}\text { Rorc_11kb_T7assay reverse primer } \\
\text { CCATTTCCCCAGCTCTGTCT }\end{array}$ & This Paper & $\mathrm{N} / \mathrm{A}$ \\
\hline $\begin{array}{l}\text { Rora qRT-PCR forward primer: } \\
\text { CATTTGTTCACGAGGCTTTCC }\end{array}$ & This Paper & $\mathrm{N} / \mathrm{A}$ \\
\hline $\begin{array}{l}\text { Rora qRT-PCR reverse primer: } \\
\text { GTTTTTCCAGTTAGCTTCCTTCATGT }\end{array}$ & This Paper & $\mathrm{N} / \mathrm{A}$ \\
\hline $\begin{array}{l}\text { Gapdh qRT-PCR forward primer: } \\
\text { AATGTGTCCGTCGTGGATCT }\end{array}$ & Sano, T. et al., 2015 & $\begin{array}{l}\text { https://www.cell.co } \\
\text { m/cell/pdfExtende } \\
\text { d/S0092- } \\
\text { 8674(15)01113-7 }\end{array}$ \\
\hline $\begin{array}{l}\text { Gapdh qRT-PCR forward primer: } \\
\text { CATCGAAGGTGGAAGAGTGG }\end{array}$ & Sano, T. et al., 2015 & $\begin{array}{l}\text { https://www.cell.co } \\
\text { m/cell/pdfExtende } \\
\text { d/S0092- } \\
8674(15) 01113-7\end{array}$ \\
\hline $\begin{array}{l}\text { Universal 16S qPCR forward primer: } \\
\text { ACTCCTACGGGAGGCAGCAGT }\end{array}$ & Sano, T. et al., 2015 & $\begin{array}{l}\text { https://www.cell.co } \\
\text { m/cell/pdfExtende } \\
\text { d/S0092- } \\
8674(15) 01113-7\end{array}$ \\
\hline $\begin{array}{l}\text { Universal 16S qPCR reverse primer: } \\
\text { ATTACCGCGGCTGCTGGC }\end{array}$ & Sano, T. et al., 2015 & $\begin{array}{l}\text { https://www.cell.co } \\
\text { m/cell/pdfExtende } \\
\text { d/S0092- } \\
\text { 8674(15)01113-7 }\end{array}$ \\
\hline $\begin{array}{l}\text { SFB 16S qPCR forward primer: } \\
\text { GACGCTGAGGCATGAGAGCAT }\end{array}$ & Sano, T. et al., 2015 & $\begin{array}{l}\text { https://www.cell.co } \\
\text { m/cell/pdfExtende } \\
\text { d/S0092- } \\
\text { 8674(15)01113-7 }\end{array}$ \\
\hline $\begin{array}{l}\text { SFB } 16 S \text { qPCR reverse primer: } \\
\text { GACGGCACGAATTGTTATTCA }\end{array}$ & Sano, T. et al., 2015 & $\begin{array}{l}\text { https://www.cell.co } \\
\text { m/cell/pdfExtende }\end{array}$ \\
\hline
\end{tabular}




\begin{tabular}{|c|c|c|}
\hline & & $\begin{array}{l}\text { d/S0092- } \\
8674(15) 01113-7\end{array}$ \\
\hline $\begin{array}{l}\text { Forward primer for } T 7 \text { endonuclease assay for } \\
\text { determining genome targeting efficiency of }+11 \mathrm{~kb} \\
\text { Rorc cis-element: } \\
\text { GTTCTTCTACCCACAGCCCT }\end{array}$ & This paper & \\
\hline $\begin{array}{l}\text { Reverse primer for T7 endonuclease assay for } \\
\text { determining genome targeting efficiency of }+11 \mathrm{~kb} \\
\text { Rorc cis-element: } \\
\text { CCATTTCCCCAGCTCTGTCT }\end{array}$ & This paper & \\
\hline \multicolumn{3}{|l|}{ Software and Algorithms } \\
\hline FlowJo & 9.9 .6 & $\begin{array}{l}\text { https://www.flowjo. } \\
\text { com/ }\end{array}$ \\
\hline Prism & 8.1 .0 & $\begin{array}{l}\text { https://www.graph } \\
\text { pad.com/scientific- } \\
\text { software/prism/ }\end{array}$ \\
\hline IMARIS software & 9.0 .1 & $\begin{array}{l}\text { Oxford } \\
\text { Instruments }\end{array}$ \\
\hline DEseq2 & 1.22 .2 & $\begin{array}{l}\text { https://bioconducto } \\
\text { r.org/packages/rel } \\
\text { ease/bioc/html/DE } \\
\text { Seq2.html }\end{array}$ \\
\hline Gene Set Enrichment Analysis tool & 3.0 & $\begin{array}{l}\text { http://software.bro } \\
\text { adinstitute.org/gse } \\
\text { a/index.jsp }\end{array}$ \\
\hline star & 2.7.3a. & $\begin{array}{l}\text { https://github.com/ } \\
\text { alexdobin/STAR }\end{array}$ \\
\hline Macs2 & & $\begin{array}{l}\text { https://github.com/ } \\
\text { macs3- } \\
\text { project/MACS }\end{array}$ \\
\hline deeptools & 3.3 .0 & $\begin{array}{l}\text { https://deeptools.r } \\
\text { eadthedocs.io/en/d } \\
\text { evelop/ }\end{array}$ \\
\hline IGV & 2.3 .91 & $\begin{array}{l}\text { http://software.bro } \\
\text { adinstitute.org/soft } \\
\text { ware/igv/ }\end{array}$ \\
\hline homer & 4.10 & $\begin{array}{l}\text { http://homer.ucsd. } \\
\text { edu/homer/ }\end{array}$ \\
\hline
\end{tabular}

\section{LEAD CONTACT AND MATERIALS AVAILABILITY}

Further information and requests for resources and reagents should be directed to and will be fulfilled by the Lead Contact, Dan R. Littman (Dan.Littman@med.nyu.edu).

\section{EXPERIMENTAL MODEL AND SUBJECT DETAILS}




\section{Mouse Strains}

All transgenic animals were bred and maintained in specific-pathogen free (SPF) conditions within the animal facility of the Skirball Institute at NYU School of Medicine. C57BL/6J mice were purchased from The Jackson Laboratory. Frozen sperm of Rora "knockout-first" mice (B6J.129S2-Rora $\left.{ }^{\text {tm1.11cs }} / \mathrm{lcs}\right)$ mice were obtained from the EMMA mouse repository and rederived onto a C57BL6/J background by NYU School of Medicine's Rodent Genetic Engineering Core. Wildtype (WT), homozygous Rora floxed $\left(\right.$ Rora $\left.^{f / f f}\right)$ mice were generated by crossing animals with $\mathrm{Tg}(\mathrm{Pgk} 1-\mathrm{flpo}) 10$ Sykr mice purchased from The Jackson Laboratories. The flp3 transgene was removed before further breeding to with $\mathrm{CD} 4^{\mathrm{Cre}}$ ( $\left.\mathrm{Tg}(\mathrm{Cd} 4-\mathrm{cre}) 1 \mathrm{Cwi} / \mathrm{BfluJ}\right) . / 117 a^{\mathrm{e} F F P}$ reporter (JAX; C57BL/6-II17a $\left.\mathrm{a}^{\mathrm{tm1Bcgen}} / \mathrm{J}\right)$ mice were purchased from The Jackson Laboratories, and bred to the Rorc (JAX; B6(Cg)-Rorctm3Litt/J) or Rora floxed mutant strains to generate the $\mathrm{T}_{\mathrm{GKO}}$ $\left(C D 4{ }^{\text {Cre }}\right.$ Rorgt $\left.^{\text {ff/fl }}\right)$ or $T_{A K O}\left(C D 4{ }^{C r e}\right.$ Rora $\left.{ }^{f / f f}\right)$ strains, respectively. $T_{G K O}$ or $T_{A K O}$ strains were further bred to the CD45.1/1 (B6.SJL-Ptprca Pepcb/BoyJ) strain to generated congenically marked lines for co-transfer experiments and mixed bone marrow chimera generation. MOG-specific TCR transgenic (2D2, JAX; C57BL/6-Tg (Tcra2D2,Tcrb2D2)1 Kuch/J) mice were purchased from The Jackson Laboratories, maintained on CD45.1 background, and bred to the $\mathrm{T}_{\text {AKO }}$ strain. RAG1 knock-out (B6.129S7-Rag1tm1Mom/J) mice were purchased from The Jackson Laboratories, and maintained on CD45.1 background. SFB-specific TCR transgenic (7B8, JAX; C57BL/6-Tg(Tcra,Tcrb)2Litt/J) mice (Yang et al., 2014) were previously described, maintained on an Ly5.1 background, and bred to the $\mathrm{T}_{\mathrm{AKO}}$ strain. RORA-TS mice were generated using CRISPR-Cas9 technology. Twin-Strep (TS) tag sequence was inserted into the last exon of the Rora locus in WT zygotes. Guide RNA and HDR donor template sequences are listed in Table S1. RORA-TS mice were bred with $\mathrm{T}_{\text {GKo }}$ mice to generate Rorc knock-out RORA-TS mice. RorgtTg (Rorgt-Cherry-CreERT2) and Rorgt $\Delta+11 \mathrm{kbTg}$ (Rorgt-Cherry-CreERT2 $\Delta+11 \mathrm{~kb})$ transgenic reporter mouse lines were generated by random insertion of bacterial artificial chromosomes (BACs) as described below. All in-house developed strains were generated by 
the Rodent Genetic Engineering Core (RGEC) at NYULMC. Age-(6-12 weeks) and sex-(both males and females) matched littermates stably colonized with Segmented Filamentous Bacteria (SFB) were used for all experiments. To assay SFB colonization, SFB-specific 16S primers were used and universal $16 \mathrm{~S}$ and/or host genomic DNA were quantified simultaneously to normalize SFB colonization in each sample. All animal procedures were performed in accordance with protocols approved by the Institutional Animal Care and Usage Committee of New York University School of Medicine.

\section{Generation of BAC transgenic reporter mice}

BAC clone RP24-209K20 was obtained from CHORI (BAC PAC) and BAC DNA was prepared using the BAC100 kit (Clontech). Purified BAC DNA was then electroporated into the recombineering bacterial line SW105. The cassette containing 50bp homology arms surrounding the Rorc(t) translational start site ATG was linked to the mCherry-P2A-iCreERT2FRT-Neo-FRT cassette by cloning into the pL451 vector. The resulting fragment was then excised using restriction digest and gel purified. Homologous recombination was performed by growing the BAC-containing SW105 cells to OD 600 and then heat shocking at $42^{\circ} \mathrm{C}$ for 15 minutes to induce expression of recombination machinery followed by cooling and washing with $\mathrm{H}_{2} \mathrm{O}$ to generate electrocompetent cells. These were then electroporated with $0.1 \mu \mathrm{g}$ of purified targeting construct DNA. Correctly recombined bacteria were selected using chloramphenicol (BAC) and Kanamycin. The resultant BAC was purified, screened for integrity of BAC and recombineering junctions by PCR. This BAC was used subsequently to make scarless deletions of putative cis-regulatory elements using GalK positive negative selection according to the Soren Warming protocol \#3. The primers, listed in Table S2, were used for generating amplicons for GalK recombineering, and screening for correct insertion and later removal of the GalK cassette. 
The primers, listed in Table S3, were used for the recombineering that led to scarless deletion of cis-elements. Correct deletions were confirmed by PCR. The Neo cassette was removed in bacteria via Arabinose inducible Flipase expression and confirmed by PCR. To generate mice, purified BAC DNA was linearized by PI-Scel digestions, dialyzed using Injection buffer (10mM Tris-HCL pH 7.5, 0.1mM EDTA, 100mM NaCl, 30 $\mu \mathrm{M}$ spermine, $70 \mu \mathrm{M}$ spermidine) to a concentration of $4 \mathrm{ng} / \mu \mathrm{l}$ for microinjection into zygotes.

\section{In vitro T cell culture and phenotypic analysis}

Mouse T cells were purified from lymph nodes and spleens of six to eight week old mice, by sorting live (DAPI $\left.{ }^{-}\right), \mathrm{CD}^{+} \mathrm{CD} 25^{-} \mathrm{CD} 62 \mathrm{~L}^{+} \mathrm{CD} 44^{\text {low }}$ naïve T cells using a FACSAria (BD). Detailed antibody information is provided in the Key Resource Table. Cells were cultured in IMDM (Sigma) supplemented with 10\% heat-inactivated FBS (Hyclone), 10U/ml penicillin-streptomycin

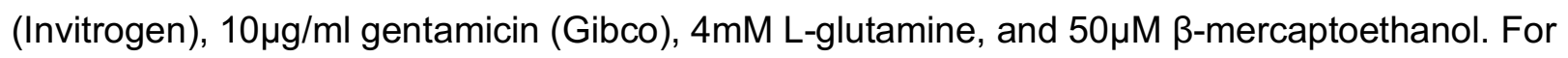
T cell polarization, $1 \times 10^{5}$ cells were seeded in $200 \mu \mathrm{l} /$ well in 96 -well plates that were pre-coated with a 1:20 dilution of goat anti-hamster IgG in PBS (STOCK $=1 \mathrm{mg} / \mathrm{ml}$, MP Biomedicals Catalog \# 55398). Naïve T cells were primed with anti-CD3ع $(0.25 \mu \mathrm{g} / \mathrm{mL})$ and anti-CD28 $(1 \mu \mathrm{g} / \mathrm{mL})$ for 24 hours prior to polarization. Cells were further cultured for $48 \mathrm{~h}$ under Th-lineage polarizing conditions; Th0 (Con. : $100 \mathrm{U} / \mathrm{mL}$ IL-2, $2.5 \mu \mathrm{g} / \mathrm{mL}$ anti-IL-4, $2.5 \mu \mathrm{g} / \mathrm{mL}$ anti-IFN $\gamma$ ), Th17

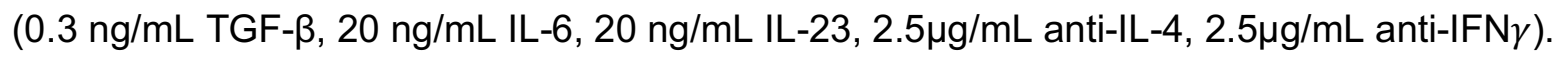

\section{METHOD DETAILS}

\section{Flow cytometry}

Single cell suspensions were pelleted and resuspended with surface-staining antibodies in HEPES Buffered HBSS containing anti-CD16/anti-CD32. Staining was performed for 20-30min on ice. Surface-stained cells were washed and resuspended in live/dead fixable blue 
(ThermoFisher) for 5 minutes prior to fixation. PE and APC-conjugated MHC class II (I-A $\left.{ }^{b}\right)$ $\mathrm{MOG}_{38-49}$ tetramers (GWYRSPFSRVVH) were provided by the NIH tetramer core facility. PE and APC-conjugated MHC class II (I-A $\left.{ }^{b}\right)$ LT $_{166-178}$ tetramers (RYYRNLNIAPAED) were produced and kindly provided by Timothy Hand's laboratory at University of Pittsburgh. Staining of tetramer positive T cells was carried out after magnetic isolation of the cells as described (Moon et al., 2009). All tetramer stains were performed at room temperature for $45-60$ minutes. For transcription factor staining, cells were treated using the FoxP3 staining buffer set from eBioscience according to the manufacturer's protocol. Intracellular stains were prepared in $1 \mathrm{X}$ eBioscience permwash buffer containing normal mouse lgG (conc), and normal rat lgG (conc). Staining was performed for $30-60 \mathrm{~min}$ on ice. For cytokine analysis, cells were initially incubated for $3 \mathrm{~h}$ in RPMI or IMDM with 10\% FBS, phorbol 12-myristate 13-acetate (PMA) (50 ng/ml; Sigma), ionomycin (500 ng/ml;Sigma) and GolgiStop (BD). After surface and live/dead staining, cells were treated using the Cytofix/Cytoperm buffer set from BD Biosciences according to the manufacturer's protocol. Intracellular stains were prepared in BD permwash in the same manner used for transcription factor staining. For EdU staining, we followed manufacturer's instruction (EdU Flow Cytometry Kit, baseclick). Absolute numbers of isolated cells from peripheral mouse tissues in all studies were determined by comparing the ratio of cell events to bead events of CountBright $^{\mathrm{TM}}$ absolute counting beads. Flow cytometric analysis was performed on an LSR II (BD Biosciences) or an Aria II (BD Biosciences) and analyzed using FlowJo software (Tree Star).

\section{Induction of EAE by MOG-immunization}

For induction of active experimental autoimmune encephalomyelitis (EAE), mice were immunized subcutaneously on day 0 with $100 \mu \mathrm{g}$ of $\mathrm{MOG}_{35-55}$ peptide, emulsified in $\mathrm{CFA}$ (Complete Freund's Adjuvant supplemented with 2mg/mL Mycobacterium tuberculosis H37Ra), and injected i.p. on days 0 and 2 with 200 ng pertussis toxin (Calbiochem). For 2D2 transfer 
EAE experiments, after retrovirus transduction and/or CAS9/RNP electroporation (described below), CD45.1/2 TwT and CD45.2/2 $\mathrm{T}_{\mathrm{AKO}} 2 \mathrm{D} 2$ cells were differentiated to ROR $\gamma \mathrm{t}^{+}$effector Th17 cells under the Th17 polarizing condition in vitro for 4 days, then were mixed 1:1 and injected intravenously into recipient mice at total $2 \times 10^{5} \mathrm{ROR} \mathrm{t}^{+} 2 \mathrm{D} 2$ cells per recipient (CD4 ${ }^{\text {Cre } / C D 45.1 / 1) . ~ T h e ~ r e c i p i e n t ~ m i c e ~ w e r e ~ s u b s e q u e n t l y ~ i m m u n i z e d ~ f o r ~ i n d u c i n g ~ E A E . ~ T h e ~}$ EAE scoring system was as follows: 0-no disease, 1- Partially limp tail; 2- Paralyzed tail; 3- Hind limb paresis, uncoordinated movement; 4- One hind limb paralyzed; 5- Both hind limbs paralyzed; 6- Hind limbs paralyzed, weakness in forelimbs; 7- Hind limbs paralyzed, one forelimb paralyzed; 8- Hind limbs paralyzed, both forelimbs paralyzed; 9- Moribund; 10- Death. For isolating mononuclear cells from spinal cords during $E A E$, spinal cords were mechanically disrupted and dissociated in RPMI containing collagenase (1 mg/ml collagenaseD; Roche), DNase I (100 $\mu \mathrm{g} / \mathrm{ml}$; Sigma) and $10 \%$ FBS at $37^{\circ} \mathrm{C}$ for $30 \mathrm{~min}$. Leukocytes were collected at the interface of a $40 \% / 80 \%$ Percoll gradient (GE Healthcare).

\section{Retroviral reconstitution of Rora or the ROR $\alpha$-target genes into $\mathrm{T}_{\mathrm{AKO}}$ 2D2 cells}

To generate the ectopic expression retrovirus vector, mouse Rora, Rorc(t) and Bhlhe40 were subcloned into the retroviral vector, MSCV-IRES-Thy1.1 (MiT). MiT-Rora, MiT-Rorc(t), MiTBhlhe40, and MiT ("empty" vector) plasmids were transfected into PLAT-E retroviral packaging cell line (Cell Bioloab, INC.) using TransIT®-293 transfection reagent (Mirus). Supernatants were collected at $48 \mathrm{~h}$ after transfection. Naive $\mathrm{T}_{\mathrm{WT}}$ or $\mathrm{T}_{\mathrm{AKO}} 2 \mathrm{D} 2$ cells were isolated and activated by plate-bound anti-CD3 and anti-CD28. 24 hours after activation, cells were spininfected by retroviruses MiT-Rora, MiT-Bhlhe40 or control empty vector (MiT-Empty) as described previously (Skon et al., 2013), then were further cultured for 96hrs under Th17lineage polarizing condition; $20 \mathrm{ng} / \mathrm{mL} \mathrm{IL}-6,20 \mathrm{ng} / \mathrm{mL} \mathrm{IL}-23,2.5 \mu \mathrm{g} / \mathrm{mL}$ anti-IL-4, $2.5 \mu \mathrm{g} / \mathrm{mL}$ anti- 
IFN $\gamma$. Prior to adoptive transfer into recipients, Thy $1.1+$ transduced cells were labeled and enriched with EasySep ${ }^{\mathrm{TM}}$ Mouse CD90.1 Positive Selection Kit (STEMCELL).

\section{CRISPR mutation of RORE in the $+11 \mathrm{~kb}$ cis-element of Rorc in 2D2 T cells}

To mutate RORE in the $+11 \mathrm{~kb}$ enhancer element of Rorc, we delivered CRISPR-Cas9 ribonucleoprotein (RNP) complexes, containing Alt-R CRISPR-Cas9 guide RNAs (the RORE targeting or control sgRNA sequences are listed in the table of STAR Methods) and Cas9 nuclease, into 2D2 cells using electroporation with the Amaxa Nucleofector system (Lonza); 20 $\mu \mathrm{M}$ (1:1.2, Cas9:sgRNA) Alt-R (Integrated DNA Technologies, Inc) Cas9 RNP complex, and 20 $\mu \mathrm{M}$ Alt-R Cas9 Electroporation Enhancer (Integrated DNA Technologies, Inc) as described previously (Vakulskas et al., 2018). sgRNAs were designed using the Crispr guide design software (Integrated DNA Technologies, Inc). FACS-sorted naïve (CD4 ${ }^{+}$CD8-CD25$\mathrm{CD}_{2} \mathrm{~L}^{+} \mathrm{CD} 44^{\text {low }}$ ) 2D2 T cells were primed for $18 \mathrm{hrs}$ in T cell medium (RPMI supplemented with 10\% FCS, 2mM b-mercaptoethanol, 2mM glutamine), along with anti-CD3 (BioXcell, clone 1452C11, $0.25 \mathrm{mg} / \mathrm{ml}$ ) and anti-CD28 (BioXcell, clone 37.5.1, $1 \mathrm{mg} / \mathrm{ml}$ ) antibodies on tissue culture plates, coated with polyclonal goat anti-hamster IgG (MP Biomedicals). RNPs were formed by the addition of purified Cas 9 protein to sgRNAs in $1 \times$ PBS. Complexes were allowed to form for $30 \mathrm{~min}$ at $37^{\circ} \mathrm{C}$ before electroporation. RNP complexes $(5 \mu \mathrm{L})$ and $1 \times 10^{6} 2 \mathrm{D} 2$ cells $(20 \mu \mathrm{L})$ were mixed and electroporated according to the manufacturer's specifications using protocol DN-100 (P3 Primary Cell 4D-Nucleofector ${ }^{\mathrm{TM}}$ ). After 4hrs of recovery in pre-warmed T cell culture medium (Mouse T Cell Nucleofector ${ }^{T M}$ Medium), the electroporated 2D2 cells were polarized into Th17 cells for $96 \mathrm{hrs}$ under Th17-lineage polarizing condition; 20 ng/mL IL-6, 20 ng/mL IL$23,2.5 \mu \mathrm{g} / \mathrm{mL}$ anti-IL-4, $2.5 \mu \mathrm{g} / \mathrm{mL}$ anti-IFN $\gamma$. For Rora reconstitution experiment described in Figure S6C, MiT-Rora, MiT-Rorc(t) and MiT (empty) retrovirus were transduced after 24hrs of the electroporation. Prior to adoptive transfer into recipients, Thy $1.1^{+}$transduced cells were labeled and enriched with EasySep ${ }^{\text {TM }}$ Mouse CD90.1 Positive Selection Kit (STEMCELL). The 
genome targeting efficiency was determined by T7 endonuclease assay (NEB) followed by manufacturer's protocol (Figure S6A). In parallel, RORE locus of the $+11 \mathrm{~kb}$ cis-element of Rorc(t) locus was PCR amplified and cloned into $\mathrm{pCR}^{\mathrm{TM}} 2.1$ vector (ThermoFisher), and mutations in the RORE locus was confirmed by sanger sequencing of the clones (Figure S6B).

\section{Generation of bone marrow (BM) chimeric reconstituted mice}

Bone marrow $(\mathrm{BM})$ mononuclear cells were isolated from donor mice by flushing the long bones. To generate $\mathrm{T}_{\mathrm{WT}} / \mathrm{T}_{\mathrm{GKO}}$ chimeric reconstituted mice, CD45.1/2 $\mathrm{T}_{\mathrm{WT}}\left(C D 4^{\mathrm{Cre}} \mathrm{RorC}^{+/+}\right)$and CD45.2/2 $\mathrm{T}_{\mathrm{GKO}}\left(C D 4^{\mathrm{Cre}}\right.$ Rorc $\left.^{\mathrm{fl/fl}}\right)$ mice were used as donors. To generate $\mathrm{T}_{\mathrm{WT}} / \mathrm{T}_{\mathrm{AKO}}$ chimeric reconstituted mice, CD45.1/2 $\mathrm{T}_{\mathrm{WT}}\left(C D 4^{\text {Cre }}\right.$ Rora $\left.^{+/+}\right)$and CD45.2/2 $\mathrm{T}_{\mathrm{AKO}}\left(C D 4^{\text {Cre }}\right.$ Rora $\left.^{\text {ff/fl }}\right)$ mice were used as donors. Red blood cells were lysed with ACK Lysing Buffer, and lymphocytes were labeled with Thy1.2 magnetic microbeads and depleted with a Miltenyi LD column. The remaining cells were resuspended in PBS for injection in at 1:4 ( $\left.T_{W T}: T_{G K O}\right)$ or 1:1 ratio ( $T_{W T:}$ $\mathrm{T}_{\text {AKO }}$ ) to achieve $1: 1$ chimerism of peripheral $\mathrm{T}$ cell populations. Total $5 \times 10^{6}$ mixed $\mathrm{BM}$ cells were injected intravenously into 6 week old RAG1 knock-out recipient mice that were irradiated $4 \mathrm{~h}$ before reconstitution using $1000 \mathrm{rads} /$ mouse (2x500rads, at an interval of $3 \mathrm{~h}$, at X-RAD 320 X-Ray Irradiator). Peripheral blood samples were collected and analyzed by FACS 7 weeks later to check for reconstitution.

\section{Oral vaccination}

Double mutant E. coli heat labile toxin (R192G/L211A) (dmLT), was produced from E. coli clones expressing recombinant protein as previously described (Norton et al., 2011). Mice were immunized twice, 7 days apart by oral gavage, and vaccine responses were assayed 2 weeks after primary gavage as described before (Hall et al., 2008).

\section{Isolation of lamina propria lymphocytes}


The intestine (small and/or large) was removed immediately after euthanasia, carefully stripped of mesenteric fat and Peyer's patches/cecal patch, sliced longitudinally and vigorously washed in cold HEPES buffered $(25 \mathrm{mM})$, divalent cation-free HBSS to remove all fecal traces. The tissue was cut into 1 -inch fragments and placed in a $50 \mathrm{ml}$ conical containing $10 \mathrm{ml}$ of HEPES buffered $(25 \mathrm{mM})$, divalent cation-free HBSS and $1 \mathrm{mM}$ of fresh DTT. The conical was placed in a bacterial shaker set to $37^{\circ} \mathrm{C}$ and $200 \mathrm{rpm}$ for 10 minutes. After 45 seconds of vigorously shaking the conical by hand, the tissue was moved to a fresh conical containing $10 \mathrm{ml}$ of HEPES buffered $(25 \mathrm{mM})$, divalent cation-free HBSS and $5 \mathrm{mM}$ of EDTA. The conical was placed in a bacterial shaker set to $37^{\circ} \mathrm{C}$ and 200 rpm for 10 minutes. After 45 seconds of vigorously shaking the conical by hand, the EDTA wash was repeated once more in order to completely remove epithelial cells. The tissue was minced and digested in 5-7ml of 10\% FBS-supplemented RPMI containing collagenase (1 mg/ml collagenaseD; Roche), DNase I (100 $\mu \mathrm{g} / \mathrm{ml}$; Sigma), dispase (0.05 U/ml; Worthington) and subjected to constant shaking at $155 \mathrm{rpm}, 37^{\circ} \mathrm{C}$ for $35 \mathrm{~min}$ (small intestine) or 55 min (large intestine). Digested tissue was vigorously shaken by hand for 2 min before adding 2 volumes of media and subsequently passed through a $70 \mu \mathrm{m}$ cell strainer. The tissue was spun down and resuspended in $40 \%$ buffered percoll solution, which was then aliquoted into a $15 \mathrm{ml}$ conical. An equal volume of $80 \%$ buffered percoll solution was underlaid to create a sharp interface. The tube was spun at 2200 rpm for 22 minutes at $22^{\circ} \mathrm{C}$ to enrich for live mononuclear cells. Lamina propria (LP) lymphocytes were collected from the interface and washed once prior to staining.

\section{SFB-specific T cell proliferation assay}

Sorted naive 7B8 or 2D2 CD45.1/1 CD4 T cells were stained with CellTrace ${ }^{\mathrm{TM}}$ Violet Cell Proliferation Kit (Life Technology) followed by manufacturer's protocol. Labeled cells were administered into SFB-colonized congenic CD45.2/2 recipient mouse by i.v. injection. MLNs of the SFB-colonized mice were collected at $96 \mathrm{~h}$ post transfer for cell division analysis. 


\section{RNA isolation and library preparation for RNA sequencing}

Total RNAs from in vitro polarized T cells or sorted cell populations were extracted using TRIzol (Invitrogen) followed by DNase I (Qiagen) treatment and cleanup with RNeasy MinElute kit (Qiagen) following manufacturer protocols. RNA-Seq libraries for ex vivo isolated IL $17^{\text {eGFP+ }} \mathrm{TWT}_{\mathrm{WT}}$ or $\mathrm{T}_{\mathrm{AKO}} \mathrm{Th17}$ lineages from DLN or spinal cords of immunized BM chimeras at peak of EAE were prepared with the SMART-Seq® v4 PLUS Kit (Takara, R400752). The sequencing was performed using the Illumina NovaSeq or NextSeq. RNA-seq libraries were prepared and sequenced by the Genome Technology Core at New York University School of Medicine.

\section{Library preparation for ATAC sequencing}

Samples were prepared as previously described (Buenrostro et al., 2013). Briefly, 50,000 sortpurified Th17 cells were pelleted in a fixed rotor centrifuge at 500xg for 5 minutes, washed once with $50 \mu \mathrm{L}$ of cold $1 \mathrm{x}$ PBS buffer. Spun down again at $500 \mathrm{xg}$ for $5 \mathrm{~min}$. Cells were gently pipetted to resuspend the cell pellet in $50 \mu \mathrm{L}$ of cold lysis buffer $(10 \mathrm{mM}$ Tris- $\mathrm{HCl}, \mathrm{pH} 7.4,10 \mathrm{mM}$ $\mathrm{NaCl}, 3 \mathrm{mM} \mathrm{MgCl}$, 0.1\% IGEPAL CA-630) for 10 minutes. Cells were then spun down immediately at $500 \mathrm{xg}$ for $10 \mathrm{~min}$ and 4 degrees after which the supernatant was discarded and proceeded immediately to the Tn5 transposition reaction. Gently pipette to resuspend nuclei in the transposition reaction mix. Incubate the transposition reaction at 37 degrees for $30 \mathrm{~min}$. Immediately following transposition, purify using a Qiagen MinElute Kit. Elute transposed DNA in $10 \mu \mathrm{L}$ Elution Buffer (10mM Tris buffer, $\mathrm{pH}$ 8). Purified DNA can be stored at -20 degrees $\mathrm{C}$. The transposed nuclei were then amplified using NEBNext High-fidelity 2X PCR master mix for 5 cycles. In order to reduce GC and size bias in PCR, the PCR reaction is monitored using qPCR to stop amplification prior to saturation using a qPCR side reaction. The additional number of cycles needed for the remaining $45 \mu \mathrm{L}$ PCR reaction is determined as following: (1) Plot linear Rn vs. Cycle (2) Set 5000 RF threshold (3) Calculate the \# of cycle that is 
corresponded to $1 / 4$ of maximum fluorescent intensity. Purify amplified library using Qiagen PCR Cleanup Kit. Elute the purified library in $20 \mu \mathrm{L}$ Elution Buffer (10mM Tris Buffer, pH 8). Be sure to dry the column before adding elution buffer. The purified libraries were then run on a high sensitivity Tapestation to determine if proper tagmentation was achieved (band pattern, not too much large untagmented DNA or small overtagmented DNA at the top or bottom of gel. Pairedend 50bp sequences were generated from samples on an Illumina HiSeq2500.

\section{Library preparation for Chromatin Immunoprecipitation (ChIP-Seq)}

ROR $\alpha$-TS and ROR $\gamma$ t ChIP-Seq was performed as described (Ciofani et al., 2012) with the following modifications. For each ChIP, 20-80 million cells were cross-linked with paraformaldehyde; chromatin was isolated using truChIP Chromatin Shearing Kit (Covaris) and fragmented with a S220 Focused-ultrasonicator (Covaris). Twin-strep (TS) tagged ROR $\alpha$ protein was precipitated using Strep-TactinXT according to the manufacturer's protocol (IBA Lifesciences). Following immunoprecipitation, the protein-DNA crosslinks were reversed and DNA was purified. DNA from control samples was prepared similarly but without immunoprecipitation. Sequencing libraries were made from the resulting DNA fragments for both ChIP and controls using DNA SMART TM ChIP-Seq Kit (Takara) for ROR $\alpha$-TS ChIP-Seq and KAPA HyperPlus Kit (Roche) for ROR $\gamma$ t ChIP-Seq. The ChIP-Seq libraries were sequenced with paired-end 50 bp reads on an Illumina HiSeq 4000.

\section{QUANTIFICATION AND STATISTICAL ANALYSIS}

\section{Transcriptome analysis}

RNA-Seq methods: Bulk RNA-Seq fastq files were aligned to the mm10 reference genome using star v 2.7.3a. Bam files were converted to bigwig files via deeptools v 3.3.0 bamCoverage for visualization. DEseq2 was used for differential gene analysis. 
ChIP-Seq methods: ChIP-Seq fastq files were aligned to the mm10 reference genome using star v 2.7.3a. Bam files were converted to bigwig files via deeptools v 3.3.0 bamCoverage and normalized by RPGC to compare peak heights across samples. Deeptools computeMatrix and plotHeatmap were used to make heatmaps. Macs2 was used to call peaks using a significance cutoff of 0.01 for the previously published ROR $\gamma$ t ChIP-Seq dataset (Ciofani et al., 2012) (Figure S4E, left panel), 0.5 for the ROR $\alpha$-Twin Strep ChIP-Seq datasets (Figure S4E, middle and right panels), and 0.05 for the ROR $\gamma$ t ChIP-Seq datasets (Figure S4I). During peak calling the treatment file was used with its associated control file. The homer annotatePeaks.pl script was used to annotate peaks within $10 \mathrm{~kb}$ of a gene.

ATAC-Seq methods: Bowtie2 was used to align the reads to the $\mathrm{mm} 10$ genome using parameters - very-sensitive. Picard tools was used to mark and remove duplicates. Deeptools bamCoverage was used to generate a bigwig file normalized using RPGC.

\section{Statistical analysis}

Differences between groups were calculated using the unpaired two-sided Welch's t-test or the two-stage step-up method of Benjamini, Krieger and Yekutieliun. For EAE disease induction, log-rank test using the Mantal-Cox method was performed. For RNA-seq analysis, differentially expressed genes were calculated in DESeq2 using the Wald test with Benjamini-Hochberg correction to determine the FDR. Genes were considered differentially expressed with FDR $<0.01$ and log2 fold change $>1.2$. Data was processed with GraphPad Prism, Version 8 (GraphPad Software). We treated less than 0.05 of $p$ value as significant differences. $* p<0.05$, $* * p<0.01, * * * p<0.001$, and $* * * * p<0.0001$. Details regarding number of replicates and the definition of center/error bars can be found in figure legends.

\section{DATA AND CODE AVAILABILITY}


The RNA-Seq, ATAC-Seq, ChIP-Seq datasets generated during this study are available at

Gene Expression Omnibus (GSE163338, GSE163340, GSE163339, GSE163341).

\section{Supplemental Tables}

Table S1 -sgRNA and HDR donor sequence, Related to STAR methods

\begin{tabular}{|c|c|c|}
\hline Oligonucleotide & Sequence & Note \\
\hline $\begin{array}{l}\text { Mouse Rora target } \\
\text { guide }\end{array}$ & GAGCCAGCTATGCAGATTGA & sgRNA \\
\hline $\begin{array}{l}\text { HDR donor DNA } \\
\text { template }\end{array}$ & $\begin{array}{l}\text { CGGAAAAGCTAATGGCATTTAAAGCAATATACCCAG } \\
\text { ACATTGTGCGACTCCATTTTCCTCCATTATACAAGGA } \\
\text { ATTGTTCACTTCAGAATTTGAGCCAGCTATGCAGATT } \\
\text { GACGGAGCAAGCGGATCGGCTTCAGGATCGGCCTC } \\
\text { TTGGTCTCACCCACAGTTCGAGAAGGGAGGCGGAT } \\
\text { CCGGAGGTGGGTCTGGCGGATCCGCTTGGTCCCAT } \\
\text { CCTCAGTTTGAAAAGTAAATGTCGCGCCCGAGCACT } \\
\text { TCTAGAACATCTGGAGTACAAACATGAAAGTAAGAG } \\
\text { AG }\end{array}$ & $\begin{array}{l}\text { Last Rora } \\
\text { Exon } \\
\text { Linker } \\
\text { Strep-tag } \\
\text { Stop } \\
\text { codons } \\
\text { Right } \\
\text { homology } \\
\text { arm }\end{array}$ \\
\hline
\end{tabular}

Table S2 - Primers for GalK recombineering and screening

\begin{tabular}{|l|l|}
\hline Primers & Sequence \\
\hline Galk Rec $+11 \mathrm{~kb} \mathrm{~F}$ & $\begin{array}{l}\text { CAAGGCTCTTCAGCCTCTACTCCAGGCTCTGCTCCAGAAAACCT } \\
\text { TTACCA CCTGTTGACAATTAATCATCGGCA }\end{array}$ \\
\hline Galk Rec $+11 \mathrm{~kb} R$ & $\begin{array}{l}\text { TGTCTATGAGCTTTCTTTTGGGAGCTTAGGCTCCAGGCTCCTTT } \\
\text { CATGC TCAGCACTGTCCTGCTCCTT }\end{array}$ \\
\hline$+11 \mathrm{~kb} H A ~ F$ & $\begin{array}{l}\text { CAAGGCTCTTCAGCCTCTACTCCAGGCTCTGCTCCAGAAAACCT } \\
\text { TTACCA }\end{array}$ \\
\hline$+11 \mathrm{~kb} H A \mathrm{R}$ & $\begin{array}{l}\text { TGTCTATGAGCTTTCTTTTGGGGAGCTTAGGCTCCAGGCTCCTTT } \\
\text { CATGC }\end{array}$ \\
\hline$+11 \mathrm{~kb}$ screen $\mathrm{F}$ & CAAGGCTCTTCAGCCTCTACTC \\
\hline$+11 \mathrm{~kb}$ screen $\mathrm{R}$ & TGTCTATGAGCTTTCTTTTGGGGA \\
\hline
\end{tabular}

Table S3 - DNA template for Rorc deletions

\begin{tabular}{|l|l|}
\hline DNA template & Sequence \\
\hline deletion & CAAGGCTCTTCAGCCTCTACTCCAGGCTCTGCTCCAGAAAACCT \\
template+11kb HA F & $\begin{array}{l}\text { TTACCAGCATGAAAGGAGCCTGGAGCCTAAGCTCCCCAAAAGA } \\
\text { AAGCTCATAGACA }\end{array}$ \\
\hline
\end{tabular}




\begin{tabular}{|l|l|}
\hline $\begin{array}{l}\text { deletion } \\
\text { template+11kb HA R }\end{array}$ & $\begin{array}{l}\text { TGTCTATGAGCTTTCTTTTGGGGAGCTTAGGCTCCAGGCTCCTT } \\
\text { TCATGCTGGTAAAGGTTTTCTGGAGCAGAGCCTGGAGTAGAGG } \\
\text { CTGAAGAGCCTTG }\end{array}$ \\
\hline
\end{tabular}

\section{References}

Abdollahi, E., Tavasolian, F., Momtazi-Borojeni, A.A., Samadi, M., and Rafatpanah, H. (2016).

Protective role of R381Q (rs11209026) polymorphism in IL-23R gene in immune-mediated diseases: A comprehensive review. J Immunotoxicol 13, 286-300.

Bamias, G., Pizarro, T.T., and Cominelli, F. (2016). Pathway-based approaches to the treatment of inflammatory bowel disease. Transl Res 167, 104-115.

Brockmann, L., Giannou, A.D., Gagliani, N., and Huber, S. (2017). Regulation of TH17 Cells and Associated Cytokines in Wound Healing, Tissue Regeneration, and Carcinogenesis. Int J Mol Sci 18.

Buenrostro, J.D., Giresi, P.G., Zaba, L.C., Chang, H.Y., and Greenleaf, W.J. (2013).

Transposition of native chromatin for fast and sensitive epigenomic profiling of open chromatin, DNA-binding proteins and nucleosome position. Nat Methods 10, 1213-1218.

Castro, G., Liu, X., Ngo, K., De Leon-Tabaldo, A., Zhao, S., Luna-Roman, R., Yu, J., Cao, T., Kuhn, R., Wilkinson, P., et al. (2017). RORgammat and RORalpha signature genes in human Th17 cells. PLoS One 12, e0181868.

Chang, D., Xing, Q., Su, Y., Zhao, X., Xu, W., Wang, X., and Dong, C. (2020). The Conserved Non-coding Sequences CNS6 and CNS9 Control Cytokine-Induced Rorc Transcription during T Helper 17 Cell Differentiation. Immunity 53, 614-626 e614.

Cheng, H.S., Lee, J.X.T., Wahli, W., and Tan, N.S. (2019). Exploiting vulnerabilities of cancer by targeting nuclear receptors of stromal cells in tumor microenvironment. Mol Cancer 18, 51.

Ciofani, M., Madar, A., Galan, C., Sellars, M., Mace, K., Pauli, F., Agarwal, A., Huang, W., Parkhurst, C.N., Muratet, M., et al. (2012). A validated regulatory network for Th17 cell specification. Cell 151, 289-303. 
Codarri, L., Gyulveszi, G., Tosevski, V., Hesske, L., Fontana, A., Magnenat, L., Suter, T., and Becher, B. (2011). RORgammat drives production of the cytokine GM-CSF in helper T cells, which is essential for the effector phase of autoimmune neuroinflammation. Nat Immunol 12, 560-567.

Cook, D.N., Kang, H.S., and Jetten, A.M. (2015). Retinoic Acid-Related Orphan Receptors (RORs): Regulatory Functions in Immunity, Development, Circadian Rhythm, and Metabolism. Nucl Receptor Res 2.

Devanna, P., and Vernes, S.C. (2014). A direct molecular link between the autism candidate gene RORa and the schizophrenia candidate MIR137. Sci Rep 4, 3994.

Duerr, R.H., Taylor, K.D., Brant, S.R., Rioux, J.D., Silverberg, M.S., Daly, M.J., Steinhart, A.H., Abraham, C., Regueiro, M., Griffiths, A., et al. (2006). A genome-wide association study identifies IL23R as an inflammatory bowel disease gene. Science 314, 1461-1463.

Durant, L., Watford, W.T., Ramos, H.L., Laurence, A., Vahedi, G., Wei, L., Takahashi, H., Sun, H.W., Kanno, Y., Powrie, F., et al. (2010). Diverse targets of the transcription factor STAT3 contribute to T cell pathogenicity and homeostasis. Immunity 32, 605-615.

El-Behi, M., Ciric, B., Dai, H., Yan, Y., Cullimore, M., Safavi, F., Zhang, G.X., Dittel, B.N., and Rostami, A. (2011). The encephalitogenicity of $T(H) 17$ cells is dependent on IL-1- and IL-23induced production of the cytokine GM-CSF. Nat Immunol 12, 568-575.

Firestein, G.S., and McInnes, I.B. (2017). Immunopathogenesis of Rheumatoid Arthritis. Immunity 46, 183-196.

Fonseca, D.M., Hand, T.W., Han, S.J., Gerner, M.Y., Glatman Zaretsky, A., Byrd, A.L., Harrison, O.J., Ortiz, A.M., Quinones, M., Trinchieri, G., et al. (2015). Microbiota-Dependent Sequelae of Acute Infection Compromise Tissue-Specific Immunity. Cell 163, 354-366.

Gaffen, S.L., Jain, R., Garg, A.V., and Cua, D.J. (2014). The IL-23-IL-17 immune axis: from mechanisms to therapeutic testing. Nat Rev Immunol 14, 585-600. 
Gieseck, R.L., 3rd, Wilson, M.S., and Wynn, T.A. (2018). Type 2 immunity in tissue repair and fibrosis. Nat Rev Immunol 18, 62-76.

Giguere, V. (1999). Orphan nuclear receptors: from gene to function. Endocr Rev 20, 689-725.

Gold, D.A., Gent, P.M., and Hamilton, B.A. (2007). ROR alpha in genetic control of cerebellum development: 50 staggering years. Brain Res 1140, 19-25.

Guntermann, C., Piaia, A., Hamel, M.L., Theil, D., Rubic-Schneider, T., Del Rio-Espinola, A., Dong, L., Billich, A., Kaupmann, K., Dawson, J., et al. (2017). Retinoic-acid-orphan-receptor-C inhibition suppresses Th17 cells and induces thymic aberrations. JCI Insight 2, e91127.

Guo, Y., Maclsaac, K.D., Chen, Y., Miller, R.J., Jain, R., Joyce-Shaikh, B., Ferguson, H., Wang, I.M., Cristescu, R., Mudgett, J., et al. (2016). Inhibition of RORgammaT Skews TCRalpha Gene Rearrangement and Limits T Cell Repertoire Diversity. Cell Rep 17, 3206-3218.

Halim, T.Y., MacLaren, A., Romanish, M.T., Gold, M.J., McNagny, K.M., and Takei, F. (2012).

Retinoic-acid-receptor-related orphan nuclear receptor alpha is required for natural helper cell development and allergic inflammation. Immunity 37, 463-474.

Haim-Vilmovsky, L., Walker, J.A., Henriksson, J., Miao, Z., Natan, E., Kar, G., et al. Rora regulates activated T helper cells during inflammation. BioRxiv 2019. doi:10.1101/709998.

Hall, J.A., Bouladoux, N., Sun, C.M., Wohlfert, E.A., Blank, R.B., Zhu, Q., Grigg, M.E., Berzofsky, J.A., and Belkaid, Y. (2008). Commensal DNA limits regulatory T cell conversion and is a natural adjuvant of intestinal immune responses. Immunity $29,637-649$.

Han, Y.H., Kim, H.J., Na, H., Nam, M.W., Kim, J.Y., Kim, J.S., Koo, S.H., and Lee, M.O. (2017). RORalpha Induces KLF4-Mediated M2 Polarization in the Liver Macrophages that Protect against Nonalcoholic Steatohepatitis. Cell Rep 20, 124-135.

Harbour, S.N., Maynard, C.L., Zindl, C.L., Schoeb, T.R., and Weaver, C.T. (2015). Th17 cells give rise to Th1 cells that are required for the pathogenesis of colitis. Proc Natl Acad Sci U S A $112,7061-7066$. 
He, Y.W., Beers, C., Deftos, M.L., Ojala, E.W., Forbush, K.A., and Bevan, M.J. (2000). Downregulation of the orphan nuclear receptor ROR gamma $t$ is essential for T lymphocyte maturation. J Immunol 164, 5668-5674.

Hirota, K., Duarte, J.H., Veldhoen, M., Hornsby, E., Li, Y., Cua, D.J., Ahlfors, H., Wilhelm, C., Tolaini, M., Menzel, U., et al. (2011). Fate mapping of IL-17-producing T cells in inflammatory responses. Nat Immunol 12, 255-263.

Honda, K., and Littman, D.R. (2016). The microbiota in adaptive immune homeostasis and disease. Nature 535, 75-84.

Hu, V.W., Sarachana, T., Kim, K.S., Nguyen, A., Kulkarni, S., Steinberg, M.E., Luu, T., Lai, Y., and Lee, N.H. (2009). Gene expression profiling differentiates autism case-controls and phenotypic variants of autism spectrum disorders: evidence for circadian rhythm dysfunction in severe autism. Autism Res 2, 78-97.

Hue, S., Ahern, P., Buonocore, S., Kullberg, M.C., Cua, D.J., McKenzie, B.S., Powrie, F., and Maloy, K.J. (2006). Interleukin-23 drives innate and T cell-mediated intestinal inflammation. J Exp Med 203, 2473-2483.

Huh, J.R., Leung, M.W., Huang, P., Ryan, D.A., Krout, M.R., Malapaka, R.R., Chow, J., Manel, N., Ciofani, M., Kim, S.V., et al. (2011). Digoxin and its derivatives suppress TH17 cell differentiation by antagonizing RORgammat activity. Nature 472, 486-490.

Jetten, A.M. (2009). Retinoid-related orphan receptors (RORs): critical roles in development, immunity, circadian rhythm, and cellular metabolism. Nucl Recept Signal 7, e003.

Kojetin, D.J., and Burris, T.P. (2014). REV-ERB and ROR nuclear receptors as drug targets. Nat Rev Drug Discov 13, 197-216.

Kopmels, B., Mariani, J., Delhaye-Bouchaud, N., Audibert, F., Fradelizi, D., and Wollman, E.E. (1992). Evidence for a hyperexcitability state of staggerer mutant mice macrophages. J Neurochem 58, 192-199. 
Lee, Y., Awasthi, A., Yosef, N., Quintana, F.J., Xiao, S., Peters, A., Wu, C., Kleinewietfeld, M., Kunder, S., Hafler, D.A., et al. (2012). Induction and molecular signature of pathogenic TH17 cells. Nat Immunol 13, 991-999.

Liljevald, M., Rehnberg, M., Soderberg, M., Ramnegard, M., Borjesson, J., Luciani, D., Krutrok, N., Branden, L., Johansson, C., Xu, X., et al. (2016). Retinoid-related orphan receptor gamma (RORgamma) adult induced knockout mice develop lymphoblastic lymphoma. Autoimmun $\operatorname{Rev} 15,1062-1070$.

Lin, C.C., Bradstreet, T.R., Schwarzkopf, E.A., Jarjour, N.N., Chou, C., Archambault, A.S., Sim, J., Zinselmeyer, B.H., Carrero, J.A., Wu, G.F., et al. (2016). IL-1-induced Bhlhe40 identifies pathogenic T helper cells in a model of autoimmune neuroinflammation. J Exp Med 213, 251271.

Lin, C.C., Bradstreet, T.R., Schwarzkopf, E.A., Sim, J., Carrero, J.A., Chou, C., Cook, L.E., Egawa, T., Taneja, R., Murphy, T.L., et al. (2014). Bhlhe40 controls cytokine production by T cells and is essential for pathogenicity in autoimmune neuroinflammation. Nat Commun 5, 3551.

Lo, B.C., Canals Hernaez, D., Scott, R.W., Hughes, M.R., Shin, S.B., Underhill, T.M., Takei, F., and McNagny, K.M. (2019). The Transcription Factor RORalpha Preserves ILC3 Lineage Identity and Function during Chronic Intestinal Infection. J Immunol 203, 3209-3215.

Lo, B.C., Gold, M.J., Hughes, M.R., Antignano, F., Valdez, Y., Zaph, C., Harder, K.W., and McNagny, K.M. (2016). The orphan nuclear receptor ROR alpha and group 3 innate lymphoid cells drive fibrosis in a mouse model of Crohn's disease. Sci Immunol 1.

Malhotra, N., Leyva-Castillo, J.M., Jadhav, U., Barreiro, O., Kam, C., O'Neill, N.K., Meylan, F., Chambon, P., von Andrian, U.H., Siegel, R.M., et al. (2018). RORalpha-expressing T regulatory cells restrain allergic skin inflammation. Sci Immunol 3. 
Marciano, D.P., Chang, M.R., Corzo, C.A., Goswami, D., Lam, V.Q., Pascal, B.D., and Griffin, P.R. (2014). The therapeutic potential of nuclear receptor modulators for treatment of metabolic disorders: PPARgamma, RORs, and Rev-erbs. Cell Metab 19, 193-208.

Maurano, M.T., Humbert, R., Rynes, E., Thurman, R.E., Haugen, E., Wang, H., Reynolds, A.P., Sandstrom, R., Qu, H., Brody, J., et al. (2012). Systematic localization of common diseaseassociated variation in regulatory DNA. Science 337, 1190-1195.

McBroom, L.D., Flock, G., and Giguere, V. (1995). The nonconserved hinge region and distinct amino-terminal domains of the ROR alpha orphan nuclear receptor isoforms are required for proper DNA bending and ROR alpha-DNA interactions. Mol Cell Biol 15, 796-808.

Melke, J., Goubran Botros, H., Chaste, P., Betancur, C., Nygren, G., Anckarsater, H., Rastam, M., Stahlberg, O., Gillberg, I.C., Delorme, R., et al. (2008). Abnormal melatonin synthesis in autism spectrum disorders. Mol Psychiatry 13, 90-98.

Miraldi, E.R., Pokrovskii, M., Watters, A., Castro, D.M., De Veaux, N., Hall, J.A., Lee, J.Y., Ciofani, M., Madar, A., Carriero, N., et al. (2019). Leveraging chromatin accessibility for transcriptional regulatory network inference in T Helper 17 Cells. Genome Res 29, 449-463. Moutinho, M., Codocedo, J.F., Puntambekar, S.S., and Landreth, G.E. (2019). Nuclear Receptors as Therapeutic Targets for Neurodegenerative Diseases: Lost in Translation. Annu Rev Pharmacol Toxicol 59, 237-261.

Netea, M.G., Balkwill, F., Chonchol, M., Cominelli, F., Donath, M.Y., Giamarellos-Bourboulis, E.J., Golenbock, D., Gresnigt, M.S., Heneka, M.T., Hoffman, H.M., et al. (2017). A guiding map for inflammation. Nat Immunol 18, 826-831.

Nguyen, A., Rauch, T.A., Pfeifer, G.P., and Hu, V.W. (2010). Global methylation profiling of lymphoblastoid cell lines reveals epigenetic contributions to autism spectrum disorders and a novel autism candidate gene, RORA, whose protein product is reduced in autistic brain.

FASEB J 24, 3036-3051. 
Nicholas, B., Rudrasingham, V., Nash, S., Kirov, G., Owen, M.J., and Wimpory, D.C. (2007). Association of Per1 and Npas2 with autistic disorder: support for the clock genes/social timing hypothesis. Mol Psychiatry 12, 581-592.

Noda, S., Krueger, J.G., and Guttman-Yassky, E. (2015). The translational revolution and use of biologics in patients with inflammatory skin diseases. J Allergy Clin Immunol 135, 324-336.

Norton, E.B., Lawson, L.B., Freytag, L.C., and Clements, J.D. (2011). Characterization of a mutant Escherichia coli heat-labile toxin, LT(R192G/L211A), as a safe and effective oral adjuvant. Clin Vaccine Immunol 18, 546-551.

Patel, D.D., and Kuchroo, V.K. (2015). Th17 Cell Pathway in Human Immunity: Lessons from Genetics and Therapeutic Interventions. Immunity 43, 1040-1051.

Pokrovskii, M. (2018). The Rorc Locus and Beyond: Deciphering the Development of RORgt+ Lymphocytes. New York University, ProQuest Dissertations Publishing, 2018. 10749170.

Sano, T., Huang, W., Hall, J.A., Yang, Y., Chen, A., Gavzy, S.J., Lee, J.Y., Ziel, J.W., Miraldi, E.R., Domingos, A.I., et al. (2015). An IL-23R/IL-22 Circuit Regulates Epithelial Serum Amyloid A to Promote Local Effector Th17 Responses. Cell 163, 381-393.

Sarachana, T., and Hu, V.W. (2013). Genome-wide identification of transcriptional targets of RORA reveals direct regulation of multiple genes associated with autism spectrum disorder. Mol Autism 4, 14.

Schraml, B.U., Hildner, K., Ise, W., Lee, W.L., Smith, W.A., Solomon, B., Sahota, G., Sim, J., Mukasa, R., Cemerski, S., et al. (2009). The AP-1 transcription factor Batf controls $\mathrm{T}(\mathrm{H}) 17$ differentiation. Nature 460, 405-409.

Shouval, D.S., Biswas, A., Kang, Y.H., Griffith, A.E., Konnikova, L., Mascanfroni, I.D., Redhu, N.S., Frei, S.M., Field, M., Doty, A.L., et al. (2016). Interleukin 1beta Mediates Intestinal Inflammation in Mice and Patients With Interleukin 10 Receptor Deficiency. Gastroenterology $151,1100-1104$. 
Song, X., Dai, D., He, X., Zhu, S., Yao, Y., Gao, H., Wang, J., Qu, F., Qiu, J., Wang, H., et al. (2015). Growth Factor FGF2 Cooperates with Interleukin-17 to Repair Intestinal Epithelial Damage. Immunity 43, 488-501.

Stockinger, B., and Omenetti, S. (2017). The dichotomous nature of T helper 17 cells. Nat Rev Immunol 17, 535-544.

Sun, Z., Unutmaz, D., Zou, Y.R., Sunshine, M.J., Pierani, A., Brenner-Morton, S., Mebius, R.E., and Littman, D.R. (2000). Requirement for RORgamma in thymocyte survival and lymphoid organ development. Science 288, 2369-2373.

Tanaka, S., Suto, A., Iwamoto, T., Kashiwakuma, D., Kagami, S., Suzuki, K., Takatori, H., Tamachi, T., Hirose, K., Onodera, A., et al. (2014). Sox5 and c-Maf cooperatively induce Th17 cell differentiation via RORgammat induction as downstream targets of Stat3. J Exp Med 211, $1857-1874$

Vakulskas, C.A., Dever, D.P., Rettig, G.R., Turk, R., Jacobi, A.M., Collingwood, M.A., Bode, N.M., McNeill, M.S., Yan, S., Camarena, J., et al. (2018). A high-fidelity Cas9 mutant delivered as a ribonucleoprotein complex enables efficient gene editing in human hematopoietic stem and progenitor cells. Nat Med 24, 1216-1224.

Wong, S.H., Walker, J.A., Jolin, H.E., Drynan, L.F., Hams, E., Camelo, A., Barlow, J.L., Neill, D.R., Panova, V., Koch, U., et al. (2012). Transcription factor RORalpha is critical for nuocyte development. Nat Immunol 13, 229-236.

Yang, X.O., Pappu, B.P., Nurieva, R., Akimzhanov, A., Kang, H.S., Chung, Y., Ma, L., Shah, B., Panopoulos, A.D., Schluns, K.S., et al. (2008). T helper 17 lineage differentiation is programmed by orphan nuclear receptors ROR alpha and ROR gamma. Immunity 28, 29-39. 
bioRxiv preprint doi: https://doi.org/10.1101/2020.12.15.422921; this version posted December 22, 2020. The copyright holder for this preprint (which was not certified by peer review) is the author/funder, who has granted bioRxiv a license to display the preprint in perpetuity. It is made Figure 1. available under aCC-BY-NC-ND 4.0 International license.

A

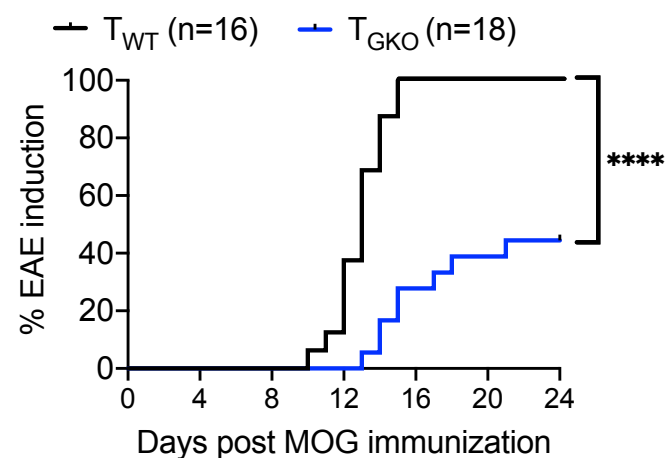

D

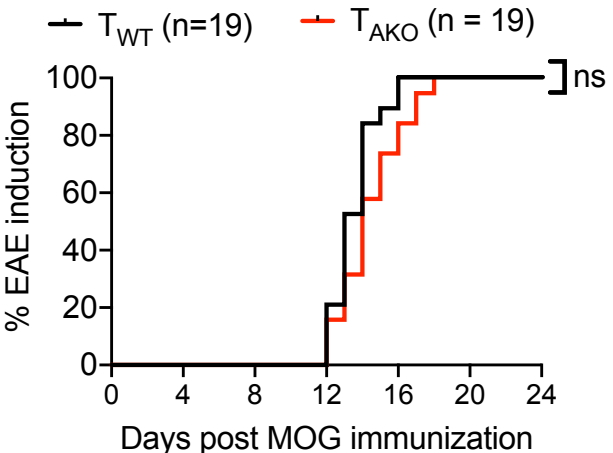

B

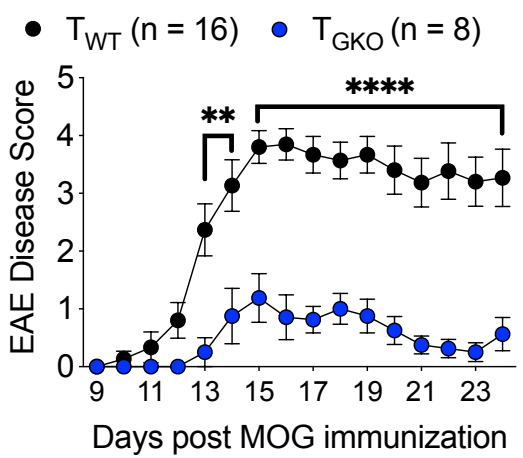

$\mathbf{E}$

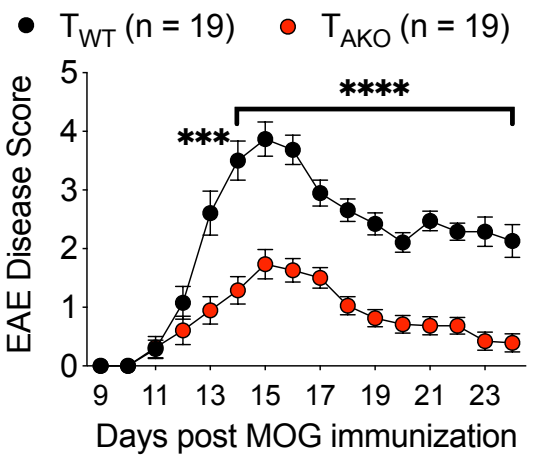

C

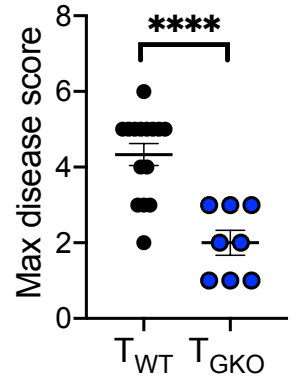

$\mathbf{F}$

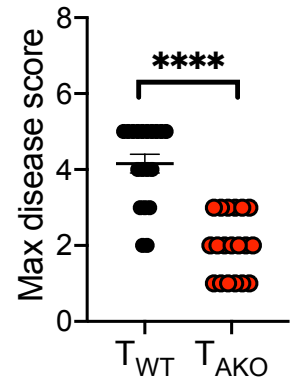

G $\quad \mathrm{T}_{\mathrm{WT}}: \mathrm{CD} 4^{\mathrm{Cre}} / \mathrm{IL} 17 \mathrm{~A}^{\mathrm{eGFP}}$ /CD45.1/2

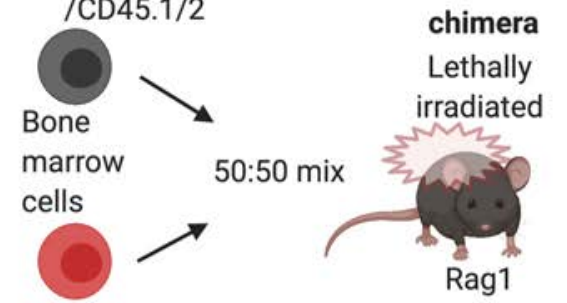

$\mathrm{T}_{\text {AKO }}:$ CD4 $4^{\text {Cre }} /$ IL17A ${ }^{\text {eGFP }} /$ Rora $^{\text {fl/fl }}$ knock-out /CD45.2/2

H DLN at peak EAE

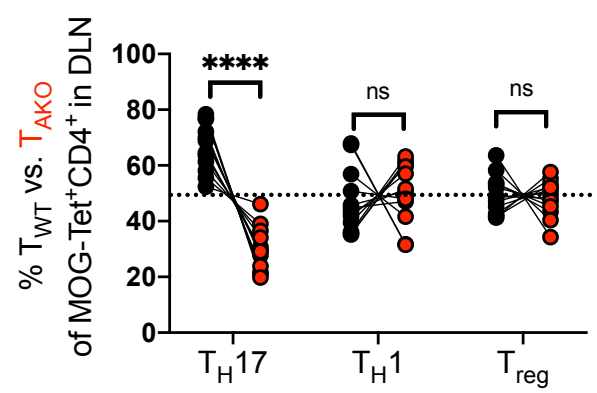

J

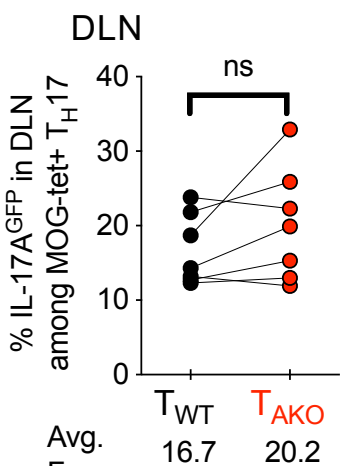

Freq.

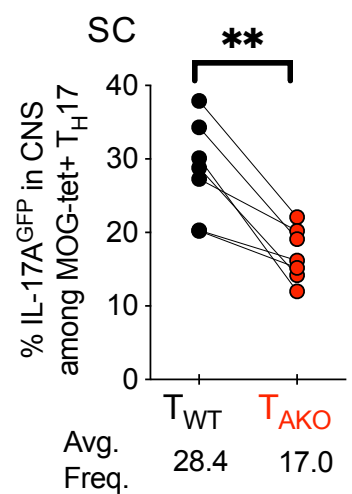

EAE immunization

$\mathrm{MOG}_{38-49}$

CFA

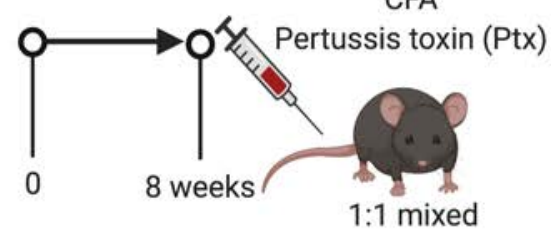

BM chimera
Tissue harvest

Draining lymph nodes (DLN)

Central nervous system (CNS)

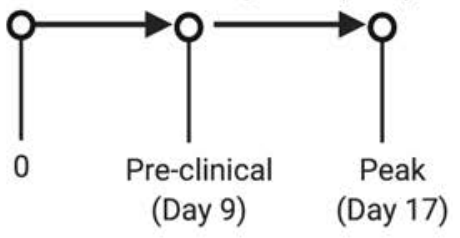

I SC at peak EAE

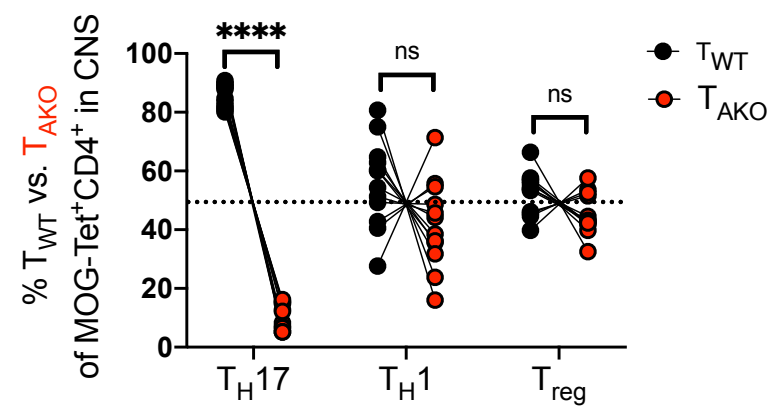

K DLN SC
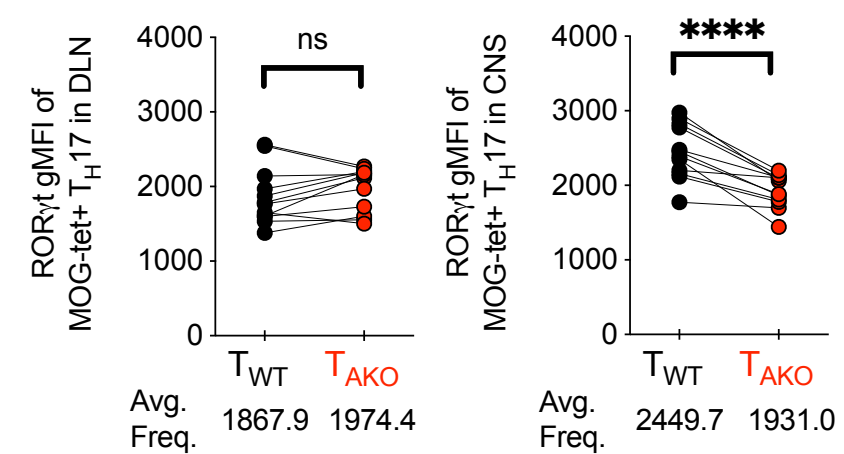
Figure 1. Divergent roles of ROR $\gamma$ t and ROR $\alpha$ in the differentiation and maintenance of pathogenic Th17 cells in autoimmune encephalomyelitis (EAE).

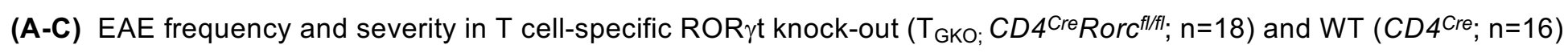
mice. Time course of EAE incidence (A) and mean daily disease score of symptomatic mice (B); maximum disease score of EAE symptomatic mice (C). Summary of 3 experiments.

(D-F) EAE frequency and severity in T cell-specific ROR $\alpha$ knock-out $\left(\mathrm{T}_{\mathrm{AKO}} ; \mathrm{CD}^{\text {Cre }} \mathrm{Rora}^{\text {fl/fl; }} \mathrm{n}=19\right)$ and WT $\left(C D 4^{C r e} ; \mathrm{n}=19\right)$, as in (A-C). Time course of EAE incidence (D) and mean daily disease score of symptomatic mice (E); maximum disease score of EAE symptomatic mice (F). Summary of 3 experiments.

(G) Schematic of EAE induction in CD45.1/2 $\mathrm{T}_{\mathrm{WT}}$ and CD45.2/2 $\mathrm{T}_{\mathrm{AKO}}$ 50:50 ( $\mathrm{T}_{\mathrm{WT}} / \mathrm{T}_{\mathrm{AKO}}$ ) mixed bone marrow (BM) chimeras. (H and I) Percent of $T_{W T}$ and $T_{A K O}$ cells of the indicated $T$ cell phenotypes among MOG-tetramer ${ }^{+}$CD4 ${ }^{+} T_{\text {cells from }}$ draining lymph node (DLN; H) or spinal cord $(\mathrm{SC} ; \mathrm{I})$ of $\mathrm{T}_{\mathrm{WT}} / \mathrm{T}_{\mathrm{AKO}} \mathrm{BM}$ chimera at peak of EAE. Each phenotypic program was determined by the specific transcription factor expression by FACS (Th17: ROR t $^{+}$FoxP3 ${ }^{\text {Neg }}{ }^{2}$ 44 ${ }^{\text {hi }}$ CD4 ${ }^{+} \mathrm{T}_{\text {cells, }}$ Th1: T-Bet $^{+}$ROR $\gamma t^{\text {Neg FoxP3 }}{ }^{\text {Neg }}$ CD44 ${ }^{\text {hi }}$ CD4 ${ }^{+}$T cells, Treg: FoxP3 ${ }^{+}$CD44 $4^{\text {hi CD }} 4^{+}$T cells).

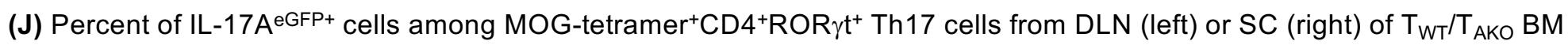
chimera at peak of EAE.

(K) ROR $\gamma$ t gMFI (geometric mean fluorescence intensity) level of MOG-tetramer ${ }^{+}$CD4 ${ }^{+}$ROR $\gamma t^{+}$Th17 cells from DLN (left) or $\mathrm{SC}$ (right) of $\mathrm{T}_{\mathrm{WT}} / \mathrm{T}_{\mathrm{AKO}} \mathrm{BM}$ chimera at peak of $\mathrm{EAE}$.

(A and D) Statistics were calculated by log-rank test using the Mantal-Cox method.

(B and E) Statistics were calculated using the two-stage step-up method of Benjamini, Krieger and Yekutieliun. Error bars denote the mean \pm s.e.m.

( $C$ and $F)$ Statistics were calculated using the unpaired sample $T$ test. Error bars denote the mean $\pm \mathrm{s} . e . \mathrm{m}$.

(E-I) Statistics were calculated using the paired sample T test. ns $=$ not significant, ${ }^{*} p<0.05,{ }^{* *} p<0.01,{ }^{* * *} p<0.001,{ }^{* * *} p$ $<0.0001$.

(H-K) Data combined from three experiments with $12 \mathrm{BM}$ chimera mice.

See also Figure S1. 
bioRxiv preprint doi: https://doi.org/10.1101/2020.12.15.422921; this version posted December 22, 2020. The copyright holder for this preprint (which was not certified by peer review) is the author/funder, who has granted bioRxiv a license to display the preprint in perpetuity. It is made

Figure S1.

A DLN at peak EAE
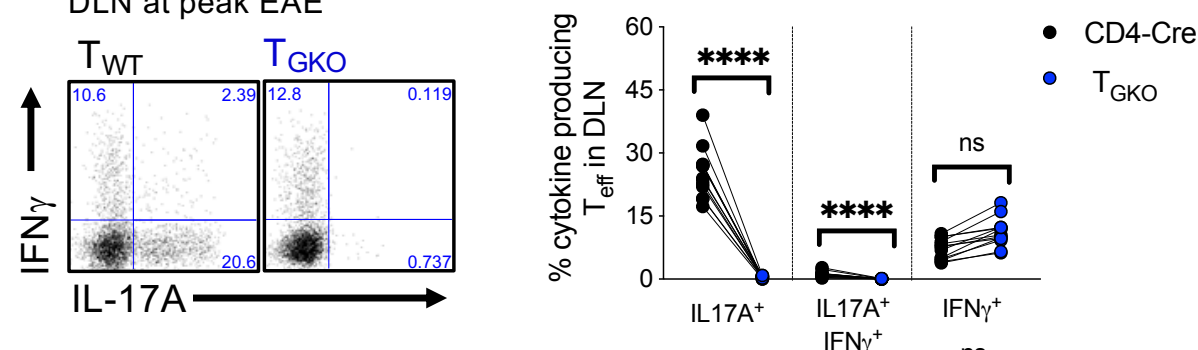

B

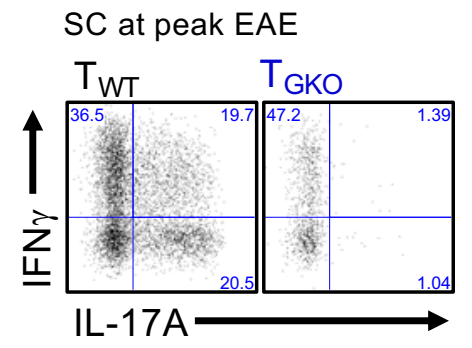
available under aCC-BY-NC-ND 4.0 International license.

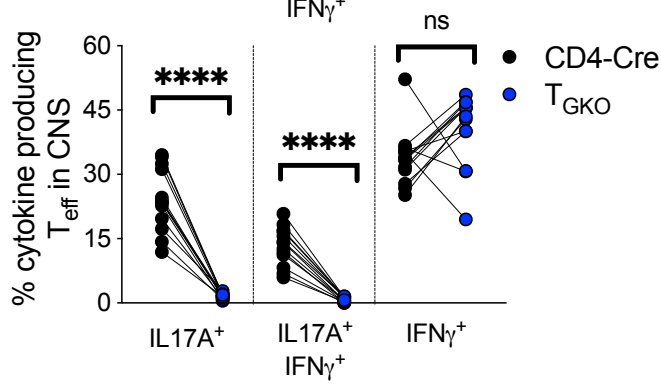

C

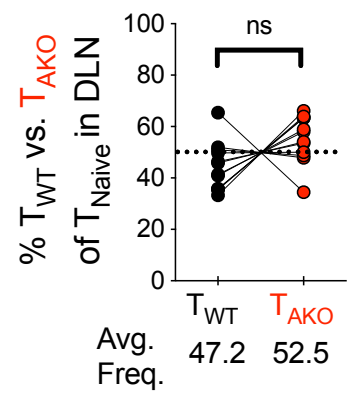

D DLN at peak EAE

CD4+TCR $\beta+$
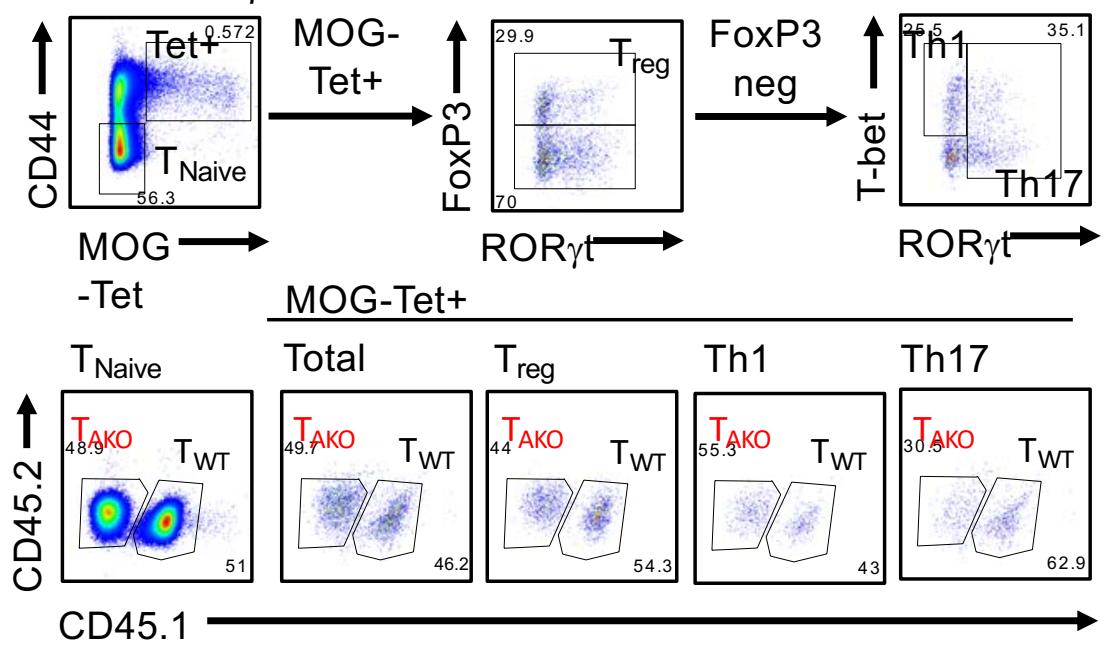

E

$S C$ at peak EAE

CD4+TCR $\beta+$

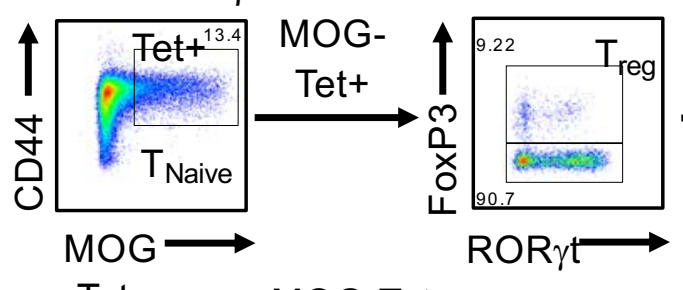

-Tet

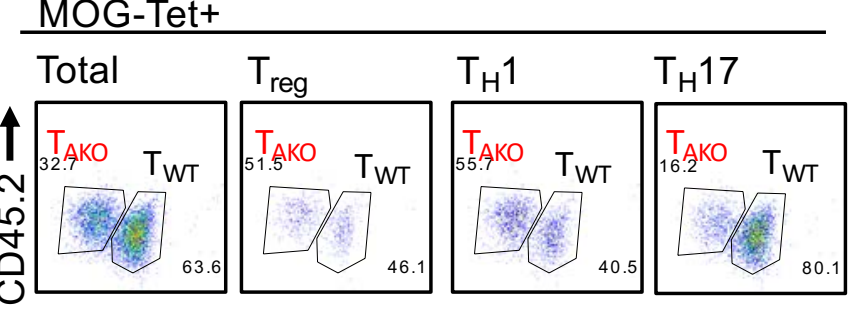

\section{F DLN}

Pre-clinical

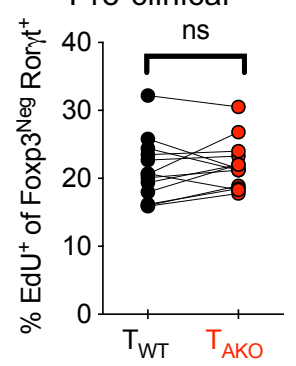

Avg. $21.1 \quad 22.0$

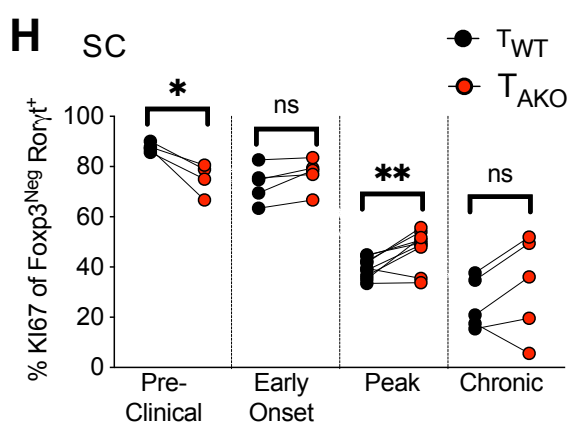


Figure S1: Role of RORyt and ROR $\alpha$ in Th17 differentiation and accumulation during autoimmune

\section{encephalomyelitis, Related to Figure 1}

(A and B) IL-17A and IFN $\gamma$ production of CD44hi effector T cells upon their ex vivo PMA/lono restimulation. Cells from $\operatorname{DLN}(A)$ and $S C(B)$ of $T_{W T} / T_{G K O} B M$ chimera at peak of EAE. Data combined three experiments with 13 BM chimera mice.

(C) Mean percent donor-derived CD44 lo $C D 4^{+}$naïve $T$ cell chimerism at peak of EAE, as determined by flow cytometric analysis of DLN. Data combined three experiments with $12 \mathrm{~T}_{\mathrm{WT}} / \mathrm{T}_{\mathrm{AKO}} \mathrm{BM}$ chimera mice.

(D and E) Gating strategies to identify all Th populations amongst MOG-tetramer ${ }^{+} \mathrm{T}_{\mathrm{WT}}$ and $\mathrm{T}_{\mathrm{AKO}}$ donor-derived CD4 ${ }^{+} \mathrm{T}$ cells in the DLN (D) and SC (E) of $\mathrm{T}_{\mathrm{WT}} / \mathrm{T}_{\mathrm{AKO}} \mathrm{BM}$ chimera mice at peak of EAE.

(F) Percent of EdU-incorporating Th17 (ROR $\gamma t^{+}$FoxP3 ${ }^{\text {neg }}$ ) cells from DLN of $T_{W T} / T_{A K O} B M$ chimera mice at pre-clinical stage of EAE. Data combined with $13 \mathrm{~T}_{\mathrm{WT}} / \mathrm{T}_{\mathrm{AKO}} \mathrm{BM}$ chimera mice.

( $G$ and $\mathbf{H}$ ) Percent of Ki-67+ Th17 (ROR $\gamma t^{+} /$FoxP3 ${ }^{\text {neg }}$ ) cells from DLN (G) and SC (H) of $T_{W T} / T_{A K O} B M$ chimera mice at indicated stages of EAE. Data combined two experiments for the pre-clinical $(n=4)$, early onset $(n=5)$, acute $(n=9)$, and chronic stages $(n=5)$ of disease, respectively.

Statistics were calculated using the paired sample T test. ns $=$ not significant, ${ }^{*} p<0.05,{ }^{* *} p<0.01,{ }^{* * * *} p<0.0001$. 
bioRxiv preprint doi: https://doi.org/10.1101/2020.12.15.422921; this version posted December 22, 2020. The copyright holder for this preprint (which was not certified by peer review) is the author/funder, who has granted bioRxiv a license to display the preprint in perpetuity. It is made

Figure 2. available under aCC-BY-NC-ND 4.0 International license.

A

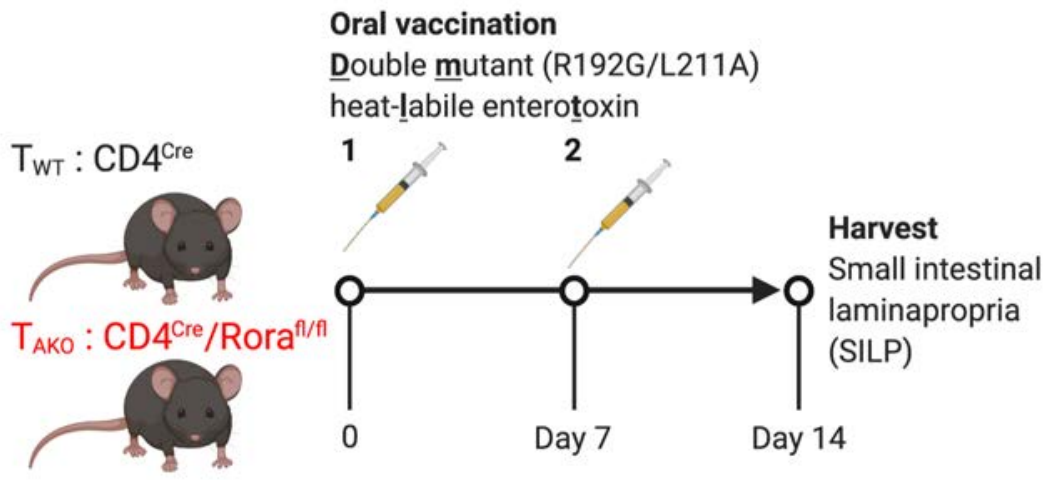

B

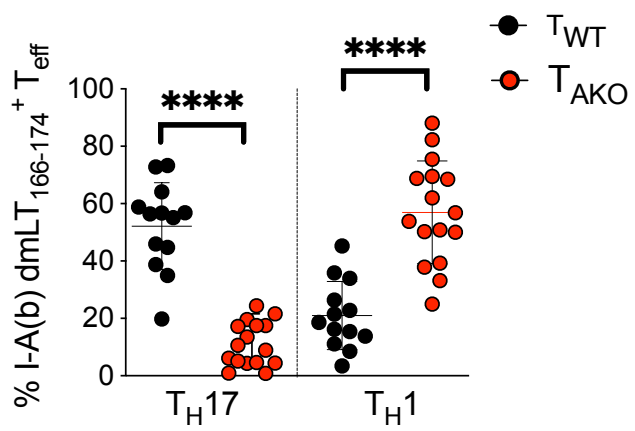

C

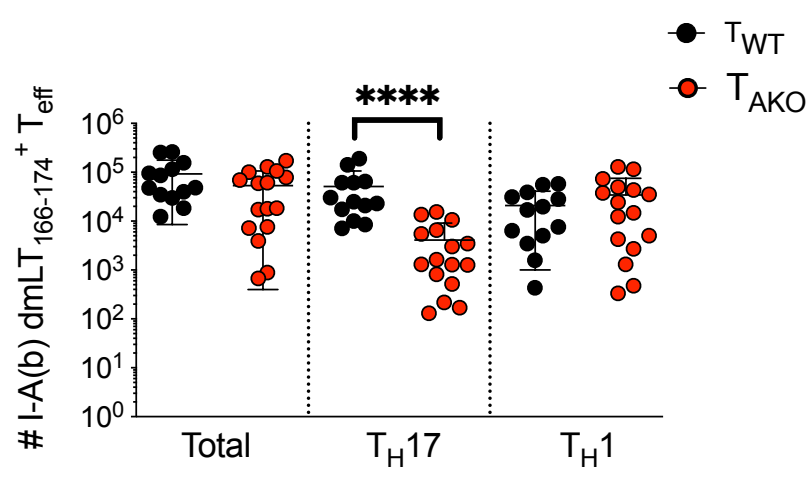

D

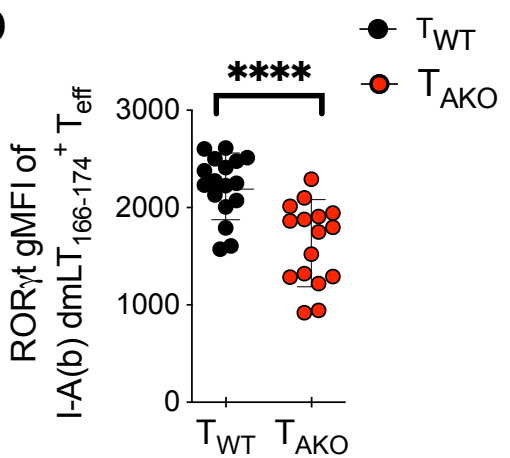

$\mathbf{F}$

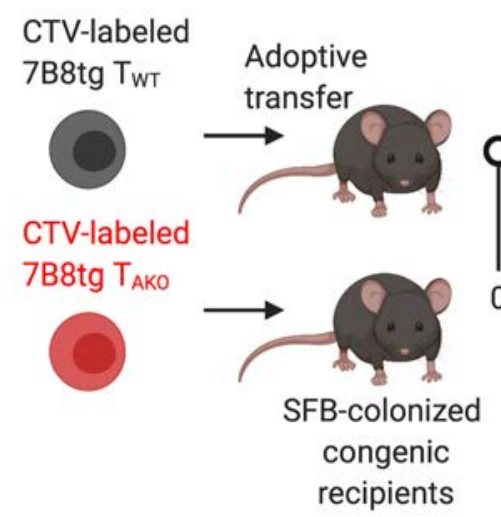

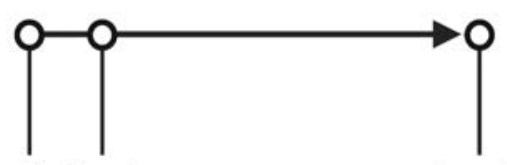

0 Day 4

Harvest

Mesenteric

lymph node (MLN)
Day 14

Harvest

Small intestinal

laminapropria (SILP)
E

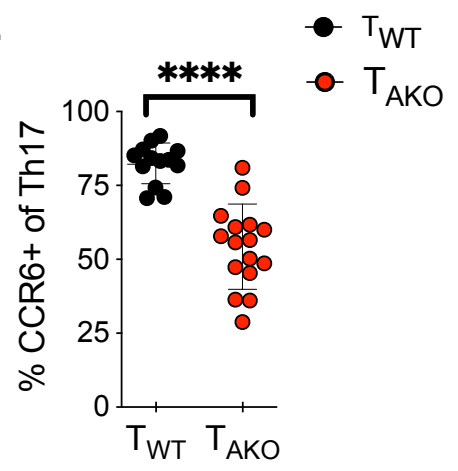

G Day 4 in MLN

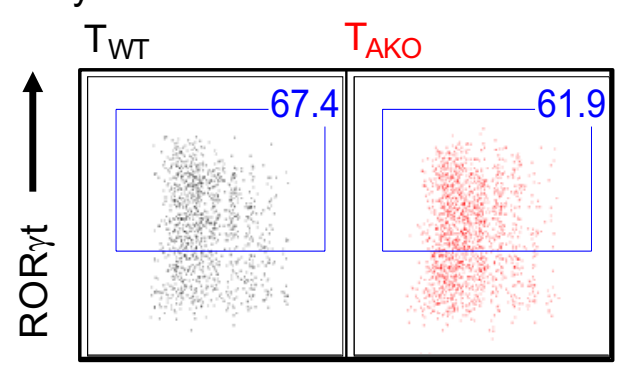

Cell proliferation
H

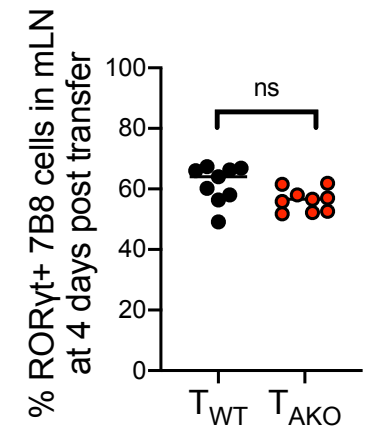

I

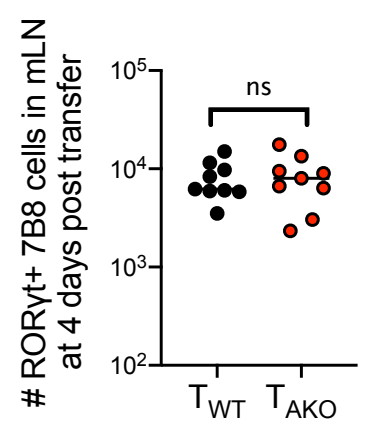

J

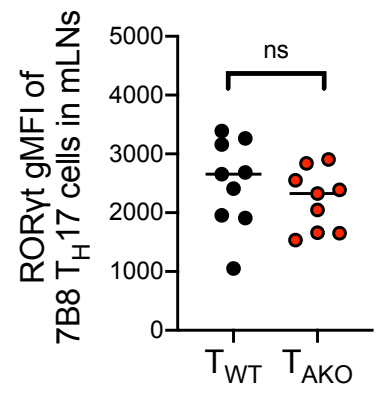

K

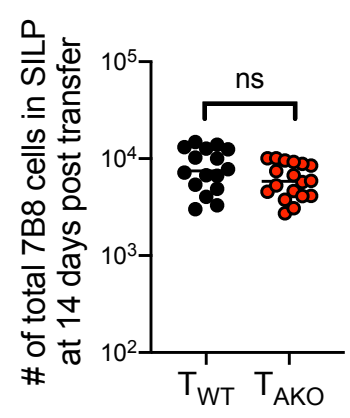

L

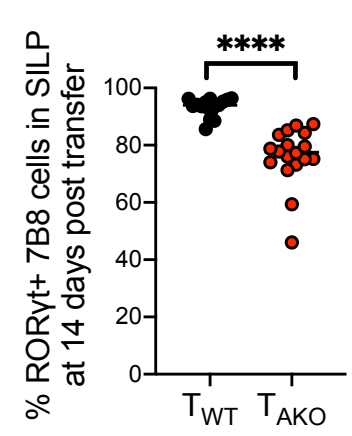

M

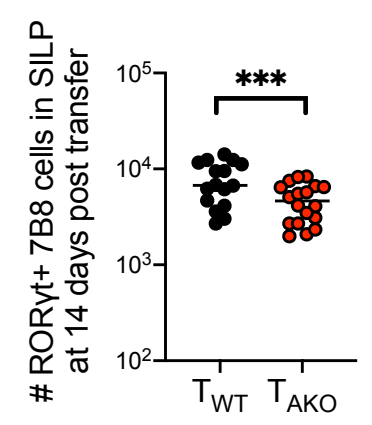

$\mathbf{N}$

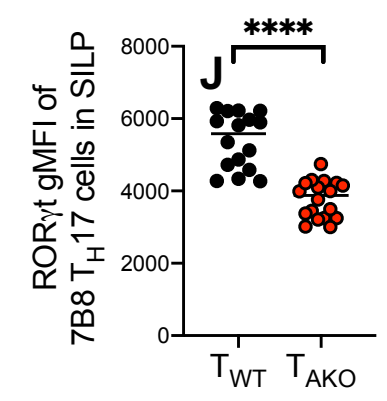


Figure 2. ROR $\alpha$ drives sustained mucosal Th17 cell responses.

(A-E) Oral vaccination of littermate $T_{W T}$ and $T_{A K O}$ mice with an attenuated double mutant (LT R192G/L211A) of the heatlabile enterotoxin of enterotoxigenic Escherichia coli, previously shown to induce a robust Th17 response.

(A) Experimental scheme to examine the role of Rora in mucosal Th17 responses.

(B and C) The proportion (B) and absolute number (C) of dmLT-specific Th17 and Th1 cells. Phenotypes were determined by FACS profiles for specific transcription factors (Th17: ROR $\gamma \mathrm{t}^{+}$FoxP3 ${ }^{\text {NegCD444hi }}{ }^{\text {hi }} 4^{+}$T cells, Th1: T-Bet ${ }^{+}$ROR $\gamma t^{\text {Neg }}$ FoxP3 ${ }^{\text {Neg }} C D 44^{\text {hi }} C D 4^{+} T$ cells, Treg: FoxP3 ${ }^{+} C D 44^{\text {hi }} C D 4^{+} T$ cells). Data combined from three experiments with $T_{W T}(n=13)$ and $T_{\text {AKO }}(n=16)$ littermates.

(D) ROR $\gamma \mathrm{t}$ gMFI of dmLT-specific Th17 cells.

(E) Percentage of dmLT-specific Th17 cells expressing CCR6.

(F-N) ROR $\alpha$ deficiency impairs SFB-specific Th17 cell accumulation in SILP.

(F) Experimental scheme to examine SFB-specific Th17 cell differentiation and effector function of 7B8tg $T_{W T}$ and $T_{A K O}$ in SFB-colonized hosts.

(G-J) Characterization of donor-derived $T_{W T}(n=9)$ and $T_{A K O}(n=9) 7 B 8 t g$ cells in recipients' mesenteric lymph nodes (MLN) at 4 days post-adoptive transfer. Flow cytometric analysis of ROR $\gamma \mathrm{t}^{+}$Th17 cell differentiation and expansion, monitored by Cell Trace Violet (CTV) dilution (G), and frequency $(\mathbf{H})$, absolute number (I) and ROR $\gamma \mathrm{t}$ gMFI level (J) of ROR $\gamma \mathrm{t}$-expressing 7B8tg cells. Data combined from two experiments.

(K-N) Characterization of donor-derived $T_{W T}(n=16)$ and $T_{A K O}(n=18) 7 B 8 t g$ cells in recipients' SILPs at 2 weeks post adoptive transfer. Summary of the total numbers (K) of SILP-accumulated 7B8tg cells, and frequency (L), absolute number (M) and ROR $\gamma \mathrm{t}$ gMFI level (N) of ROR $\gamma$ t expressing 7B8tg cells. Data combined from three experiments.

Statistics were calculated using the unpaired sample $T$ test. Error bars denote the mean \pm s.e.m. ns $=$ not significant, ${ }^{*} p<$ $0.05,{ }^{* * *} p<0.001,{ }^{* * * *} p<0.0001$.

See also Figure S2. 


\section{Figure S2.} available under aCC-BY-NC-ND 4.0 International license.

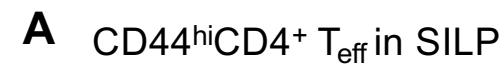

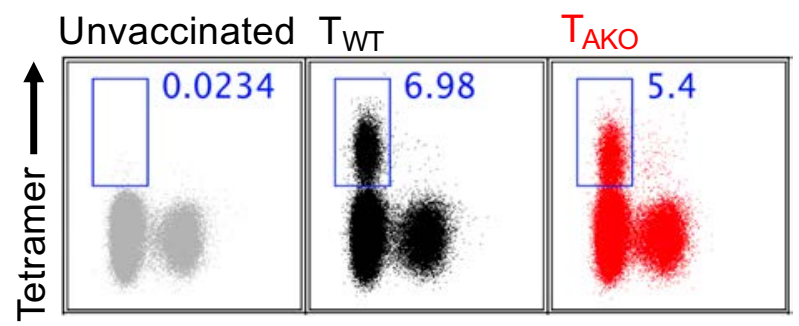

FoxP3
B

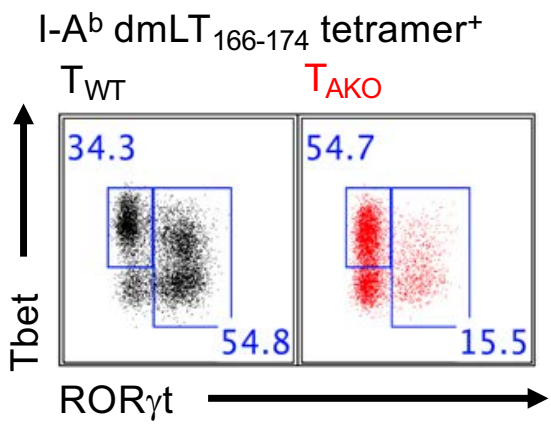

C $\mathrm{I}^{-\mathrm{A}^{\mathrm{b}} \mathrm{dmLT}} \mathrm{T}_{166-174}$ tetramer $^{+}$ $\mathrm{ROR} \gamma \mathrm{t}^{+}$

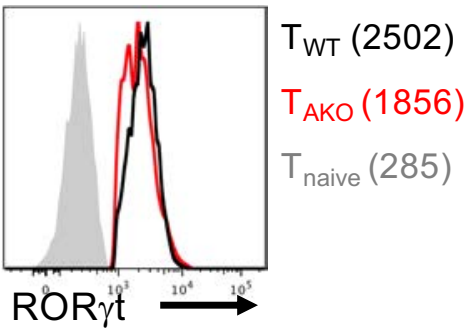

D

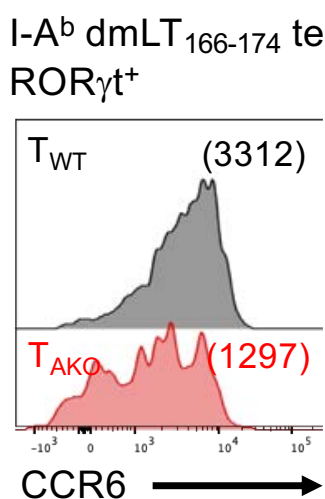

E

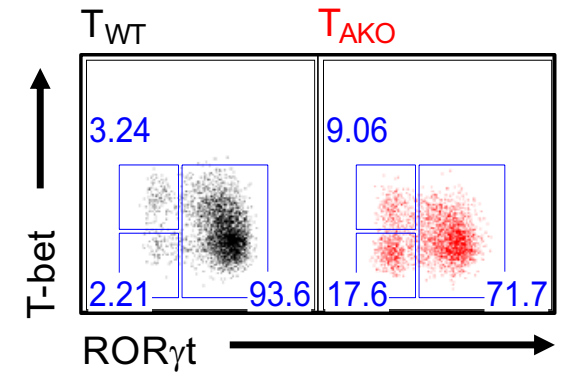

$\mathbf{F}$

7B8 cells at 2 weeks in SILP $\mathrm{ROR} \gamma \mathrm{t}^{+}$

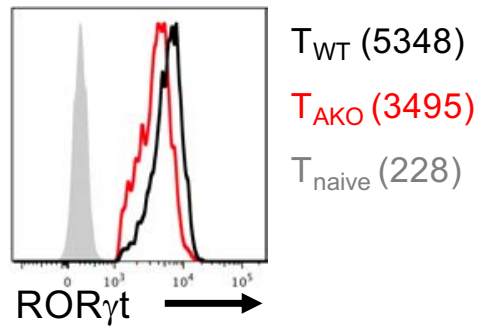

Figure S2. ROR $\alpha$ deficiency impairs Th17 cell accumulation in SILP. Related to Figure 2

(A) Small intestinal lamina propria $C D 4^{+} \mathrm{CD} 44^{+} \mathrm{T}$ cells were stained for $\mathrm{I}-\mathrm{A}^{\mathrm{b}} \mathrm{dmLT}$ 166-174 tetramer binding and Foxp3 expression to compare the $\mathrm{dmLT}$-specific $\mathrm{CD} 4^{+} \mathrm{T}$ cell effector responses between $\mathrm{T}_{\mathrm{WT}}$ and $\mathrm{T}_{\mathrm{AKO}}$ mice.

(B) Gated dmLT tetramer ${ }^{+} \mathrm{T}$ cells from representative $\mathrm{T}_{\mathrm{WT}}$ (black dot plot) and $\mathrm{T}_{\mathrm{AKO}}$ (red dot plot) SILP were analyzed for expression of T-bet and ROR $\gamma$ t.

(C and D) Histograms depicting expression of ROR $\gamma \mathrm{t}(\mathrm{C})$ and CCR6 (D) in $\mathrm{T}_{\mathrm{WT}}$ and $\mathrm{T}_{\mathrm{AKO}}$ dmLT tetramer ${ }^{+} \mathrm{ROR}_{\gamma} \mathrm{t}^{+} \mathrm{Th} 17$ cells. Geometric mean fluorescence intensities (gMFI) are included in parentheses.

(E) Representative flow cytometric analysis of SILP-accumulated $T_{W T}$ (black dot plot) and $T_{A K O}$ (red dot plot) 7B8tg cells at 2 weeks post adoptive transfer.

(F) Histogram of ROR $\gamma$ t expression in $\mathrm{T}_{\mathrm{WT}}$ and $\mathrm{T}_{\mathrm{AKO}}$ ROR $\gamma \mathrm{t}^{+}$7B8 Th17 cells. Geometric mean fluorescence intensities $(\mathrm{gMFI})$ are included in parentheses. 
bioRxiv preprint doi: https://doi.org/10.1101/2020.12.15.422921; this version posted December 22, 2020. The copyright holder for this preprint (which was not certified by peer review) is the author/funder, who has granted bioRxiv a license to display the preprint in perpetuity. It is made Figure 3. available under aCC-BY-NC-ND 4.0 International license.

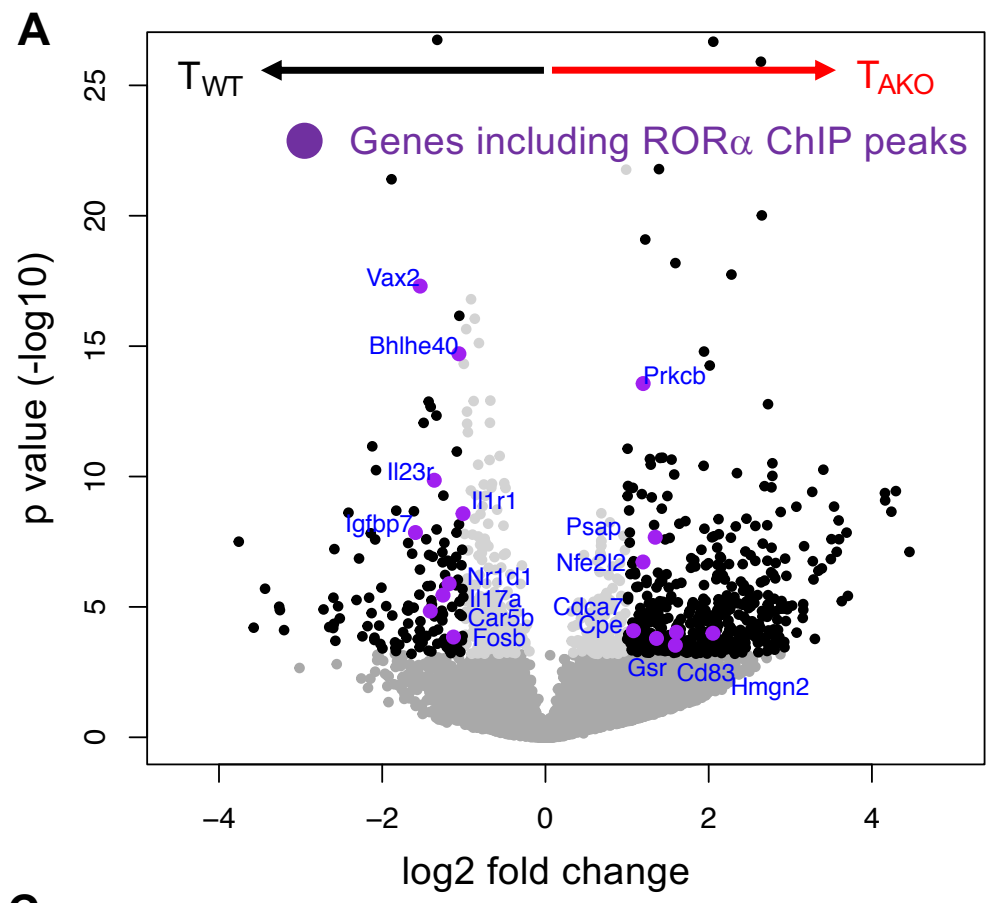

\section{Rorc}

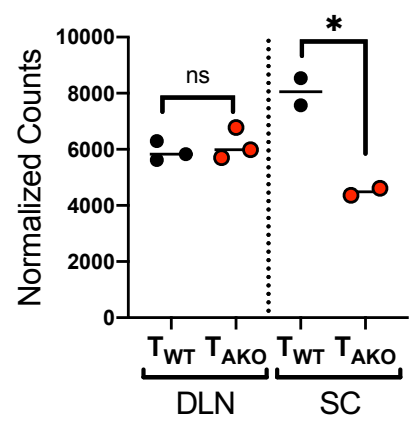

B $\quad / 11 r 1$

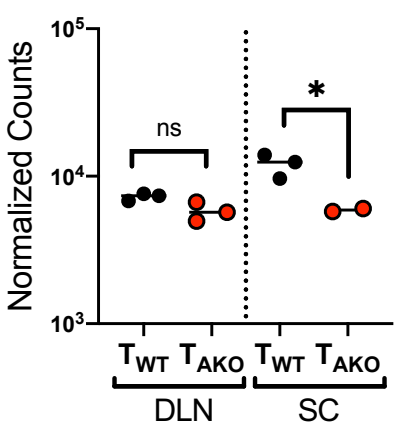

Bhlhe40

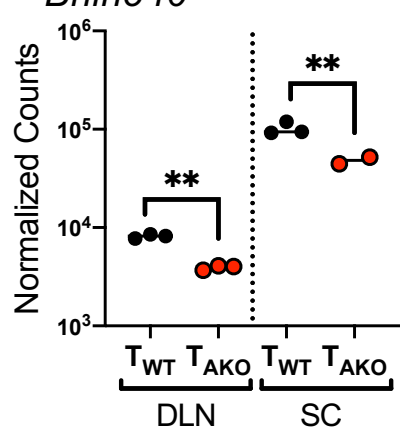

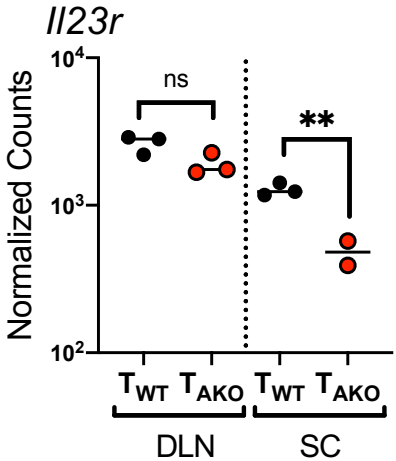

Csf2

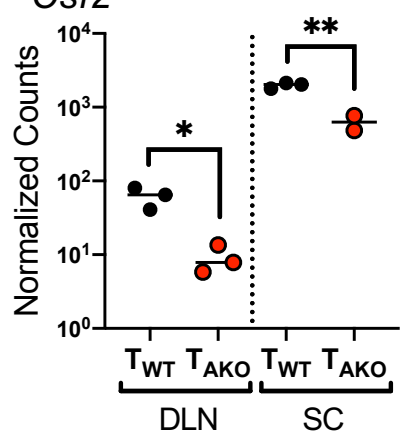

E

E SC at peak of EAE: 2D2 donors

$T_{W T}$-Empty $T_{A K O}$-Empty $T_{A K O}$-Rora

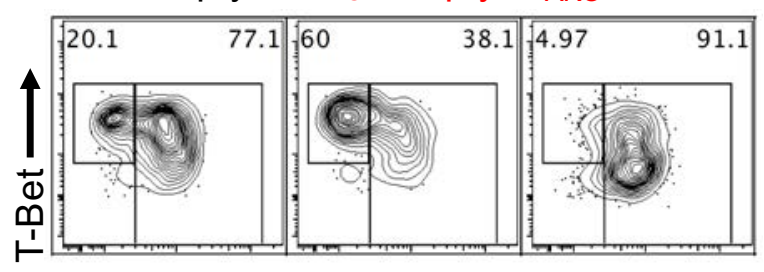

$\mathrm{ROR} \gamma \mathrm{t}$

I

SC at peak EAE: 2D2 donors

TWT -Empty $\mathrm{T}_{\text {AKO }}$-Empty $\mathrm{T}_{\mathrm{AKO}}$-Bhlhe40

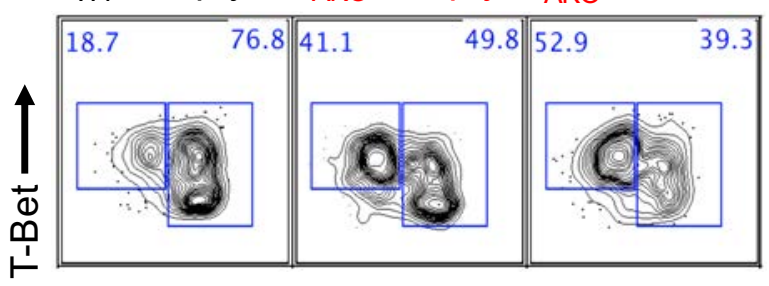

$\mathrm{ROR} \gamma \mathrm{t}$
$2 \mathrm{D} 2 \mathrm{~T}_{\mathrm{WT}}: 2 \mathrm{D} 2 / \mathrm{CD}^{\mathrm{Cre}} / \mathrm{CD} 45.1 / 2$

Days

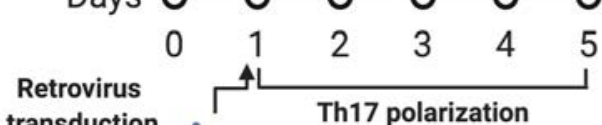

1. Empty IL6+TGF $3+$ IL 23

2. Rora

$\mathbf{F}$

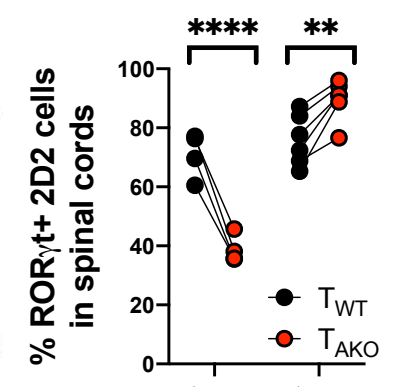

1:1 adoptive transfer

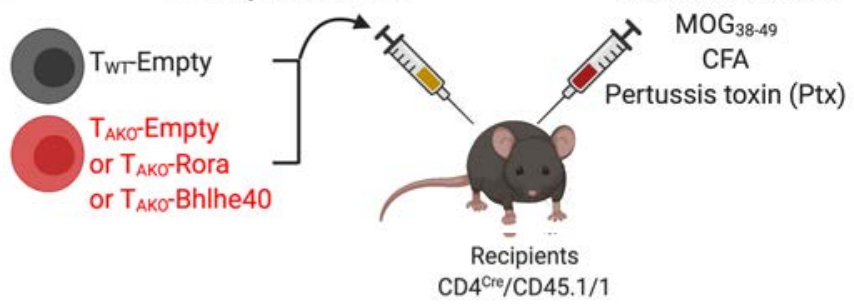

G

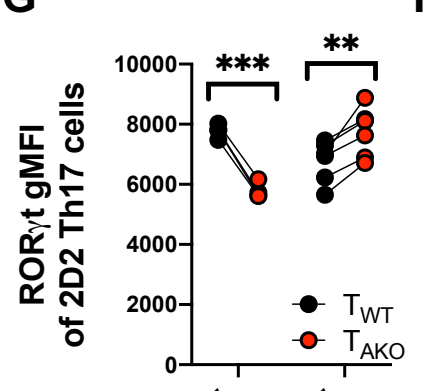

H

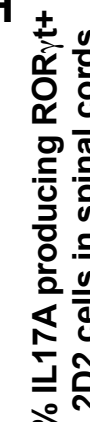

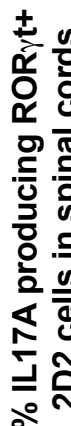

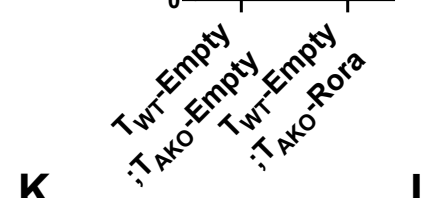

K

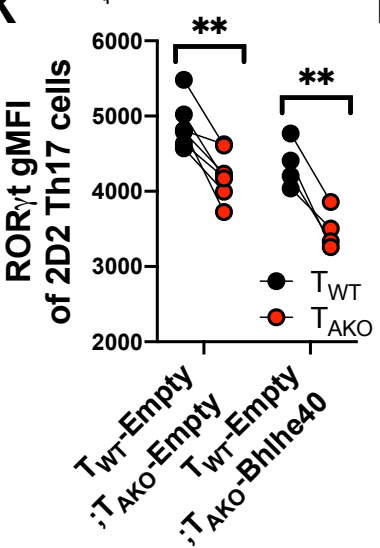

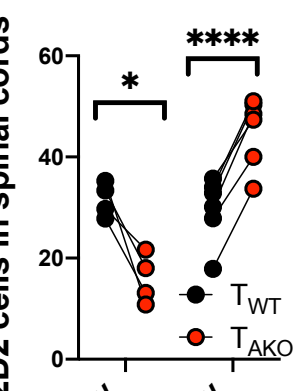

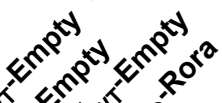

人心

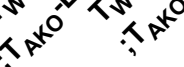

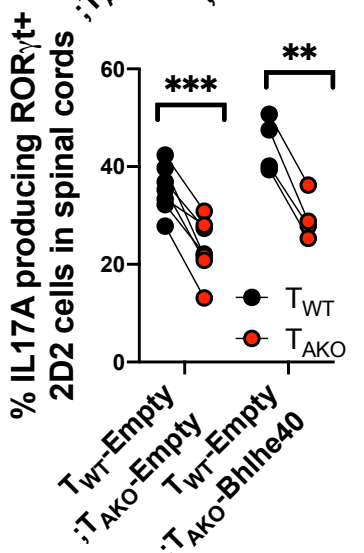


Figure 3. ROR $\alpha$ stabilizes the Th17 transcriptional program in effector tissues

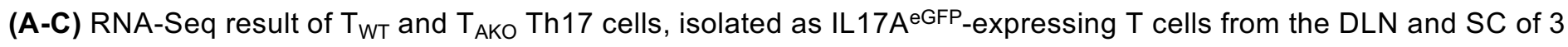
separate cohorts of mixed BM chimera mice at peak of EAE.

(A) Volcano plot depicting differentially expressed (DE) genes of $T_{W T}$ versus $T_{A K O}$ IL17AeGFP+ Th17 cells from the SC. Black dots are significant DE genes. DE genes were calculated in DESeq2 using the Wald test with Benjamini-Hochberg correction to determine the false discovery rate (FDR < 0.01). Purple dots highlight genes that include ROR $\alpha$ ChIP-Seq peaks within $10 \mathrm{~kb}$ of the gene body.

(B and C) Normalized counts of autoimmune disease-associated (I/1r1, I/23r, Bh/he40), pathogenic (Csf2) genes (B) and Rorc (C) in $T_{W T}$ and $T_{A K O} / 117 a^{e G F P+}$ Th17 cells from the DLN $\left(T_{W T}(n=3)\right.$ and $\left.T_{A K O}(n=3)\right)$ and SC $\left(T_{W T}(n=3)\right.$ and $T_{A K O}(n$ $=2)$ ) at peak of EAE. Statistics were calculated using the unpaired sample $T$ test. ns $=$ not significant, ${ }^{*} p<0.05,{ }^{* *} p<0.01$.

(D) Experimental scheme to examine the role of ROR $\alpha$ and BHLHE40 in maintenance of the auto-reactive effector Th17 program in inflamed SC during EAE. 2D2tg $\mathrm{T}_{\mathrm{WT}}(\mathrm{CD} 4 \mathrm{Cre} / \mathrm{CD} 45.1 / 2)$ or $\mathrm{T}_{\mathrm{AKO}}$ (CD4Cre/Rorafl/fl/CD45.2/2) cells were retrovirally transduced with Rora or Bhlhe 40 or control (Empty) vector, then in vitro polarized to Th17 cells (with IL-6+TGF$\beta+I L-23)$ for 5 days. The polarized $T_{W T}$ and $T_{A K O} 2 D 2$ cells were combined 1:1 and transferred into recipients (CD4Cre/ CD45.1/1) followed by EAE induction (MOG + CFA + Pertussis toxin immunization).

(E) Flow cytometry analysis of ROR $\gamma$ t and T-bet expression of $\mathrm{T}_{\mathrm{WT}}$, Rora-deficient ( $\mathrm{T}_{\mathrm{AKO}}$-Empty) and Rora-reconstituted ( $T_{A K O}$-Rora) $2 \mathrm{D} 2$ cells in SC at peak of EAE.

(F and G) Frequency (F) and ROR $\gamma \mathrm{tgMFI}(\mathbf{G})$ of ROR $\gamma \mathrm{t}^{+}$2D2tg cells amongst donor $\mathrm{T}_{\mathrm{AKO}}-\mathrm{Empty}_{\text {or }} \mathrm{T}_{\mathrm{AKO}}-\mathrm{R}_{\mathrm{R}}$ ra $2 \mathrm{D} 2 \mathrm{tg}$ cells compared to the $\mathrm{T}_{\mathrm{WT}}$-Empty in spinal cord at peak of EAE.

(H) Frequency of indicated IL-17A-producing donor-derived 2D2tg-Th17 cells in SC at peak of EAE following ex vivo $\mathrm{PMA} /$ lonomycin re-stimulation.

(I) Flow cytometry analysis of ROR $\gamma$ t and T-bet expression of $T_{W T}-E m p t y$ and $T_{A K O}-E m p t y$ or Bhlhe40 ectopic expressing ( $\left.T_{A K O}-B h l h e 40\right)$ cells in spinal cord at peak of EAE.

( $\mathbf{J}$ and K) Frequency $(\mathrm{J})$ and ROR $\mathrm{Rt}$ gMFI (K) of ROR $\mathrm{t}^{+} \mathrm{T}_{\mathrm{AKO}}-$ Empty or $\mathrm{T}_{\mathrm{AKO}}-$ Bhlhe40 2D2 $\mathrm{T}_{\mathrm{AKO}}$ cells compared to $\mathrm{T}_{\mathrm{WT}}$ Empty.

(L) Frequency of indicated IL-17A-producing donor-derived 2D2tg-Th17 cells in SC at peak of EAE following ex vivo $\mathrm{PMA} /$ lonomycin re-stimulation.

$(E-H)$ Summary of 2 experiments, with $T_{W T}-E m p t y: T_{A K O}-E m p t y(n=4)$ and $T_{W T}-E m p t y: T_{A K O}-R o r a(n=6)$ recipients. Statistics were calculated using the paired sample $T$ test. ${ }^{*} p<0.05,{ }^{* *} p<0.01,{ }^{* * *} p<0.001,{ }^{* * * *} p<0.0001$.

(I-L) Summary of 2 experiments, with $\mathrm{T}_{\mathrm{WT}}$-Empty: $\mathrm{T}_{\mathrm{AKO}}-$ Empty $(n=7)$ and $\mathrm{T}_{\mathrm{WT}}-$ Empty: $\mathrm{T}_{\mathrm{AKO}}-\mathrm{Bh}$ lhe40 $(n=4)$ recipients. Statistics were calculated using the paired sample $T$ test. ${ }^{*} p<0.05,{ }^{* *} p<0.01,{ }^{* * *} p<0.001,{ }^{* * *} p<0.0001$. See also Figure S3. 
bioRxiv preprint doi: https://doi.org/10.1101/2020.12.15.422921; this version posted December 22, 2020. The copyright holder for this preprint (which was not certified by peer review) is the author/funder, who has granted bioRxiv a license to display the preprint in perpetuity. It is made

Figure S3. available under aCC-BY-NC-ND 4.0 International license.
A RNA-Seq of IL17AGFP+ Th cells
B from $S C$ or DLN during peak of EAE

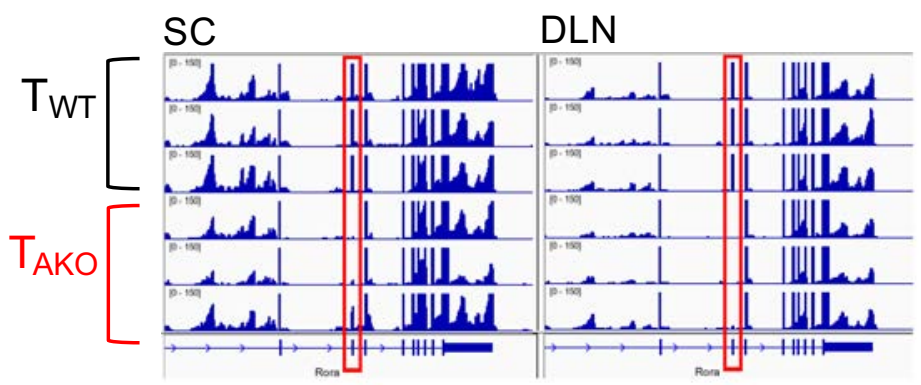

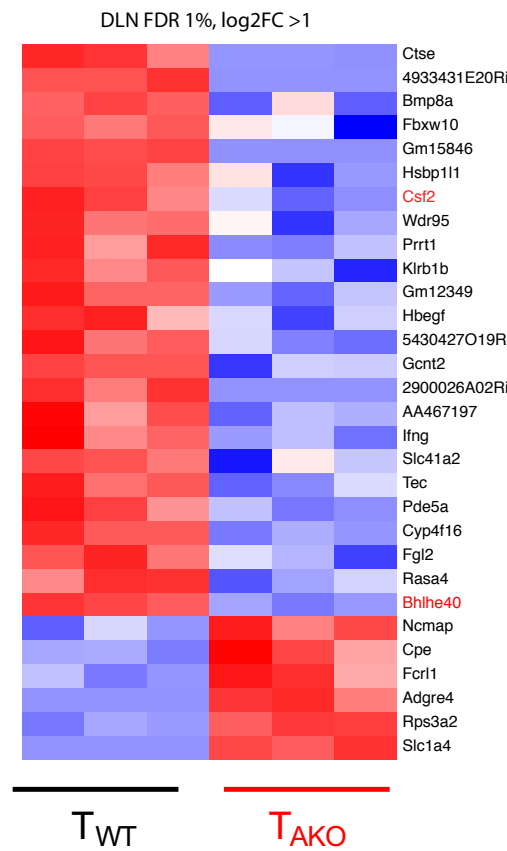

D In vitro polarized 2D2 Th17 cells

TwT-Empty $\quad T_{W T}$-Empty

TAKO-Empty $\quad T_{\text {AKO-Rora }}$

Isotype con

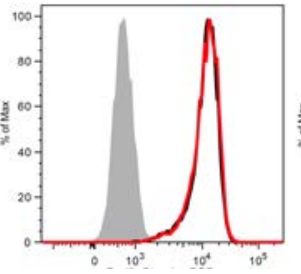

$\mathrm{ROR} \gamma \mathrm{t}$

G

SC at peak EAE: 2D2 ROR $\gamma \mathrm{t}+$ Th17 donors

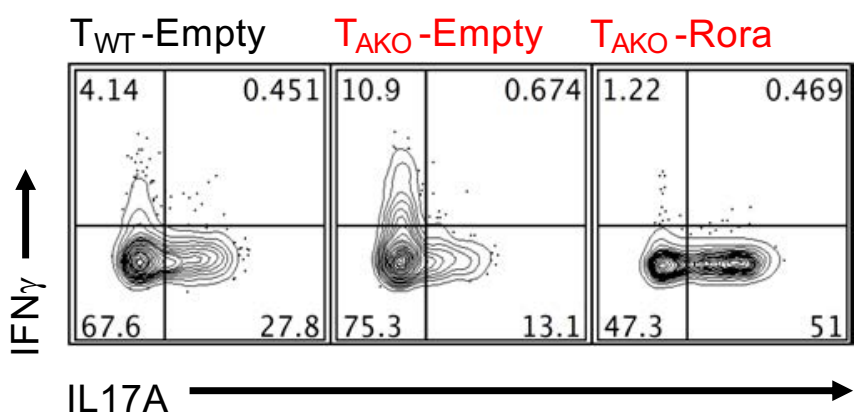

I

SC at peak EAE: 2D2 donors

TWT-Empty $\quad T_{W T}$ Empty

$\mathrm{T}_{\mathrm{AKO}}$-Empty $\quad \mathrm{T}_{\mathrm{AKO}}$-Bhlhe40
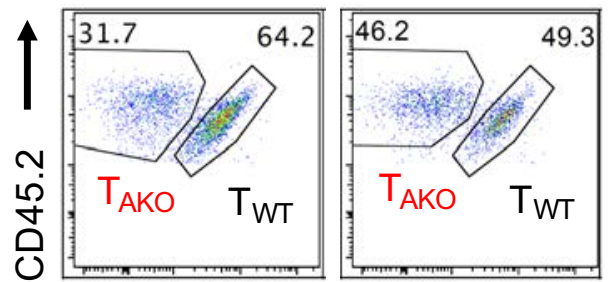

CD45.1

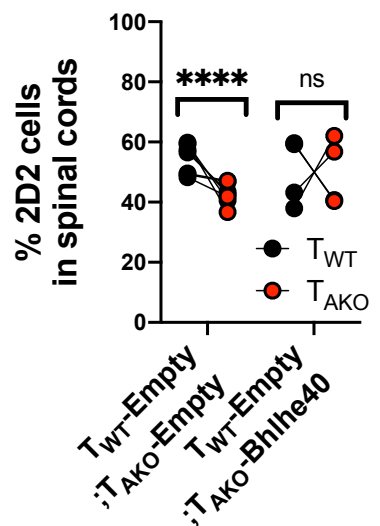

C SC at peak EAE

CNS FDR $1 \%, \log 2$ FC $>1$

Pathogenic Genes Nonpathogenic Genes
ChIP seq differentially

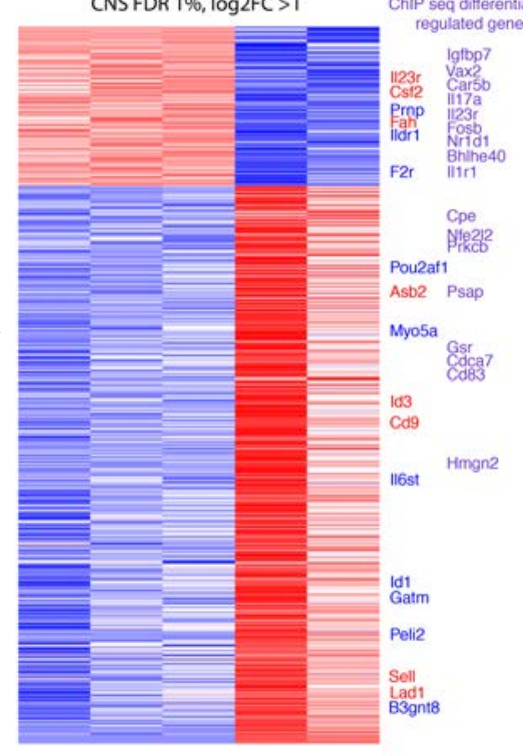

$\overline{F^{T_{W T}}} \overline{T_{\text {AKO }}}$

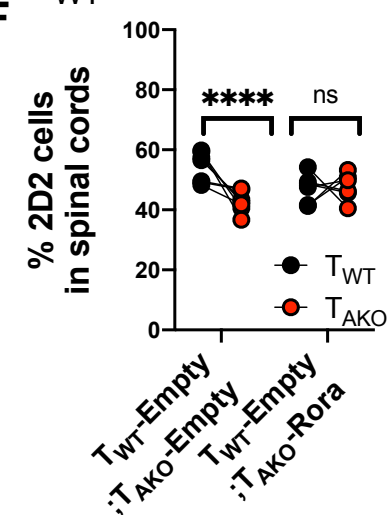

CD45.1

H In vitro polarized 2D2 Th17 cells

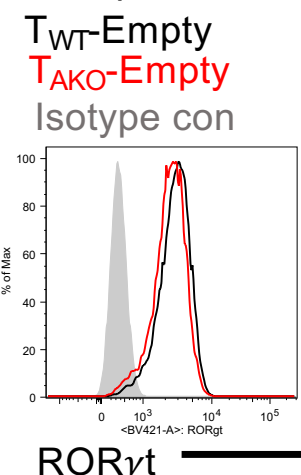

K SC at peak EAE: 2D2 ROR $\gamma \mathrm{t}+\mathrm{Th} 17$ donors

$\mathrm{T}_{\mathrm{WT}}$-Empty $\quad \mathrm{T}_{\mathrm{AKO}}$-Empty $\mathrm{T}_{\mathrm{AKO}}$-Bhlhe40

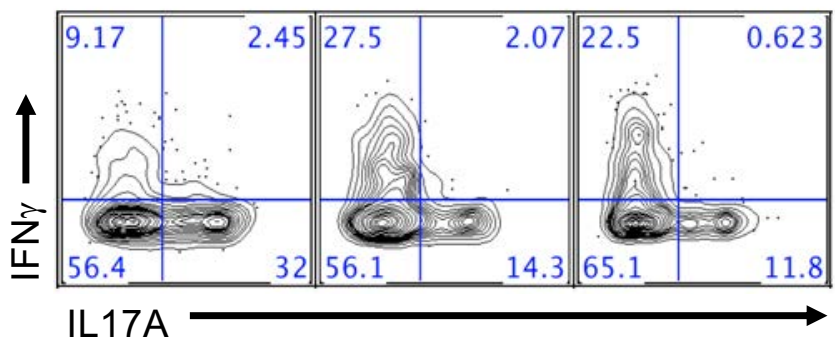


Figure S3. Target genes of ROR $\alpha$, and rescue of EAE phenotype with $\mathrm{T}_{\text {AKO }}$ cells expressing ectopic ROR $\alpha$ or its target gene product Bhlhe40. Related to Figure 3

(A-C) RNA-Seq analysis to identify target genes of ROR $\alpha$. RNA preparation from sorted $/ 117 a^{e G F P+}$ mice is described in Methods. One SC $\mathrm{T}_{\mathrm{AKO}}$ Th17 sample contained reads in the deleted region of the Rora locus and thus was excluded from analysis; all other $\mathrm{T}_{\mathrm{AKO}}$ samples were devoid of reads in this region (A). (A) RNA-Seq tracks within Rora locus indicating efficient inducible deletion of Rora (Exon3) of $/ 117 a^{e G F P+} T_{W T}$ and $T_{A K O}$ Th17 cells from DLN and SC of mixed BM chimera mice at peak of EAE. (B and C) Clustered heatmap of differentially expressed genes between $/ 17 a^{e G F+} T^{\text {Th } 17} \mathrm{~T}_{\mathrm{WT}}$ and $\mathrm{T}_{\mathrm{AKO}}$ cells from DLN (B) and SC (C) of mixed BM chimera mice at peak of EAE. Color scale is based on z-scores for each gene. Genes listed on the righthand margin are color coded. Blue = non-pathogenic Th17 signature. Red = pathogenic Th17 signature. Purple $=$ Genes associated with ROR $\alpha$ ChIP-Seq peaks.

(D-K) Reconstitution of 2D2 $\mathrm{T}_{\mathrm{AKO}}$ cells with ROR $\alpha$ or Bhlhe40 and phenotypic analysis in spinal cords during EAE. (D) Stacked histogram illustrating representative ROR $\gamma$ t expression of in vitro polarized 2D2tg T $\mathrm{WT}_{\mathrm{T}}$-Empty and ROR $\alpha$-deficient ( $\left.T_{A K O}-E m p t y\right)$ or -reconstituted ( $T_{A K O}$-Rora) Th17 cells. ( $E$ and $\left.F\right)$ Representative FACS plots $(E)$ and frequency $(F)$ of cotransferred $\mathrm{T}_{\mathrm{WT}}$ and $\mathrm{T}_{\mathrm{AKO}}$ donor-derived 2D2tg cells, retrovirally reconstituted with or without Rora, in the SC at peak of EAE. (G) Representative FACS plots displaying IL-17A and IFN $\gamma$ production of ROR $\gamma \mathrm{t}^{+}$Th17 $\mathrm{T}_{\mathrm{AKO}}-\mathrm{Empty}_{\text {or }} \mathrm{T}_{\mathrm{AKO}}-\mathrm{Rora} 2 \mathrm{D} 2$ cells compared to $\mathrm{T}_{W T}$-Empty upon ex vivo PMA/lonomycin restimulation. $(\mathrm{H})$ Stacked histogram illustrating representative ROR $\gamma$ t expression of in vitro polarized 2D2tg $T_{W T}$-Empty and Rora-deficient ( $T_{A K O}$-Empty) or Bhlhe40-overexpressing ( $\left.T_{A K O}-B h l h e 40\right)$ Th17 cells. (I and J) Representative FACS plots $(\mathrm{I})$ and frequencies $(\mathrm{J})$ of co-transferred $\mathrm{T}_{\mathrm{WT}}$ and $\mathrm{T}_{\mathrm{AKO}}$ donor-derived 2D2tg cells, retrovirally transduced with or without Bhlhe40, in the SC at peak of EAE. (K) Representative FACS plots displaying IL-17A and IFN $\gamma$ production of ROR $\gamma \mathrm{t}^{+}$Th17 $\mathrm{T}_{\mathrm{AKO}}-\mathrm{Empty}$ or $\mathrm{T}_{\mathrm{AKO}}-\mathrm{Bh}$ lhe40 $2 \mathrm{D} 2$ cells compared to $\mathrm{T}_{\mathrm{WT}}$-Empty upon ex vivo PMA/lonomycin re-stimulation.

Data combined from two experiments. Statistics were calculated using the paired sample $\mathrm{T}$ test. ns $=$ not significant, ${ }^{*} \mathrm{p}<$ $0.05,{ }^{* *} p<0.01,{ }^{* * *} p<0.001,{ }^{* * * *} p<0.0001$. 
bioRxiv preprint doi: https://doi.org/10.1101/2020.12.15.422921; this version posted December 22, 2020. The copyright holder for this preprint (which was not certified by peer review) is the author/funder, who has granted bioRxiv a license to display the preprint in perpetuity. It is made Figure 4. available under aCC-BY-NC-ND 4.0 International license.

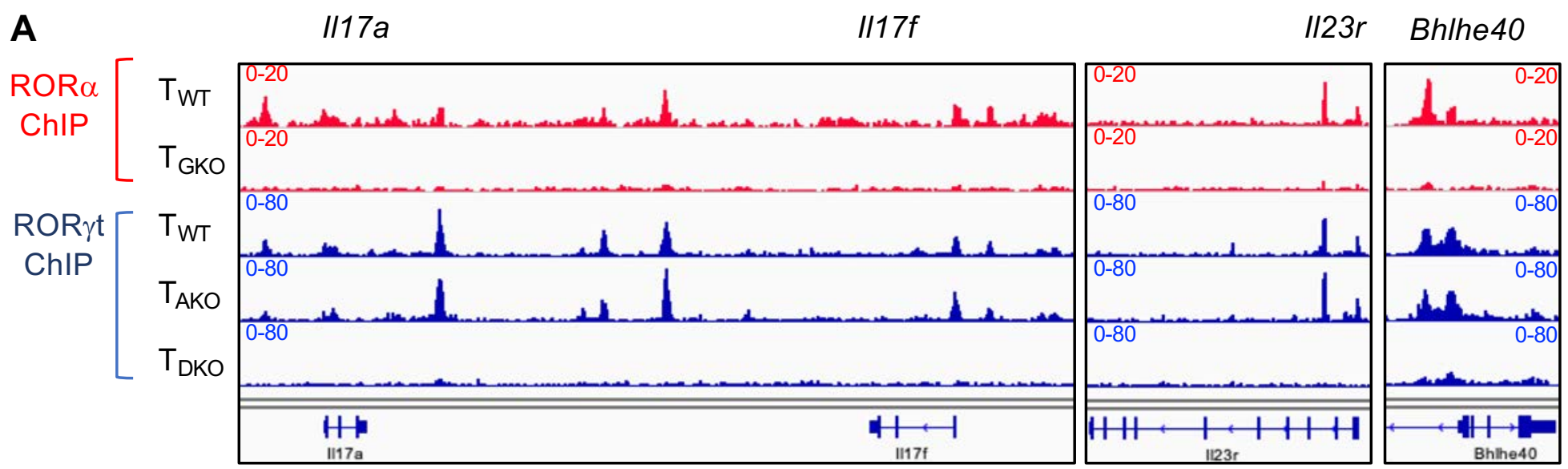

B Gene ontology (GO) enrichment analysis of ROR $\alpha$ target genes

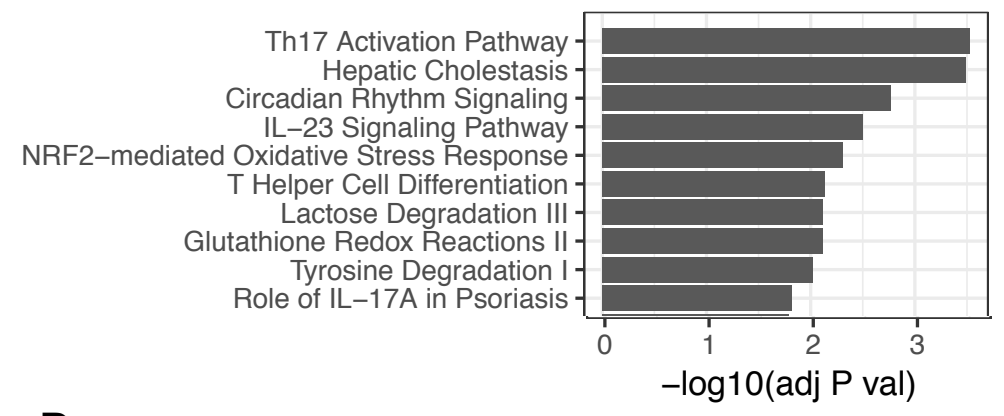

C

D ATAC-Seq: mouse Th17
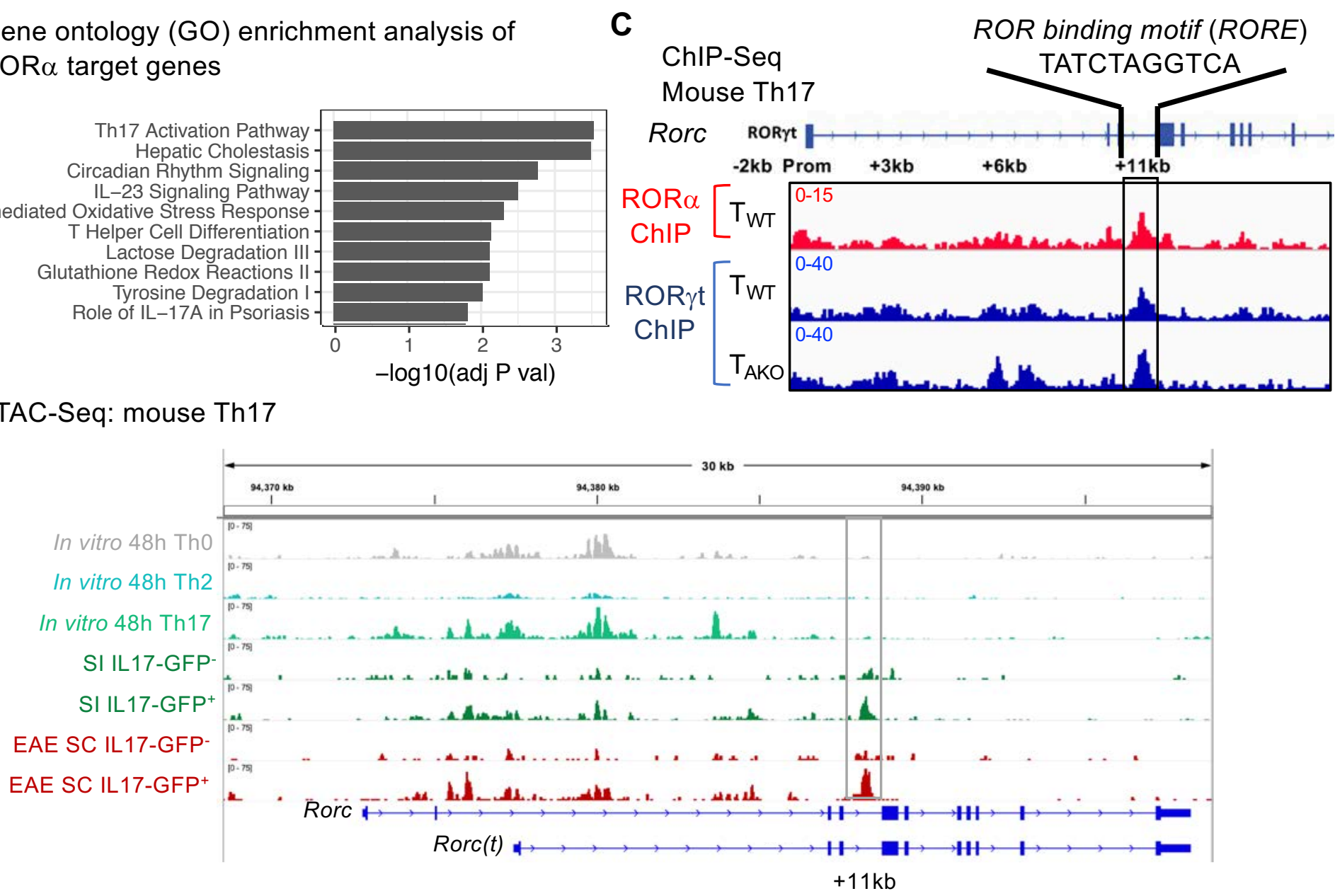

\section{E DNase-Seq: human PBMC}

RORC locus

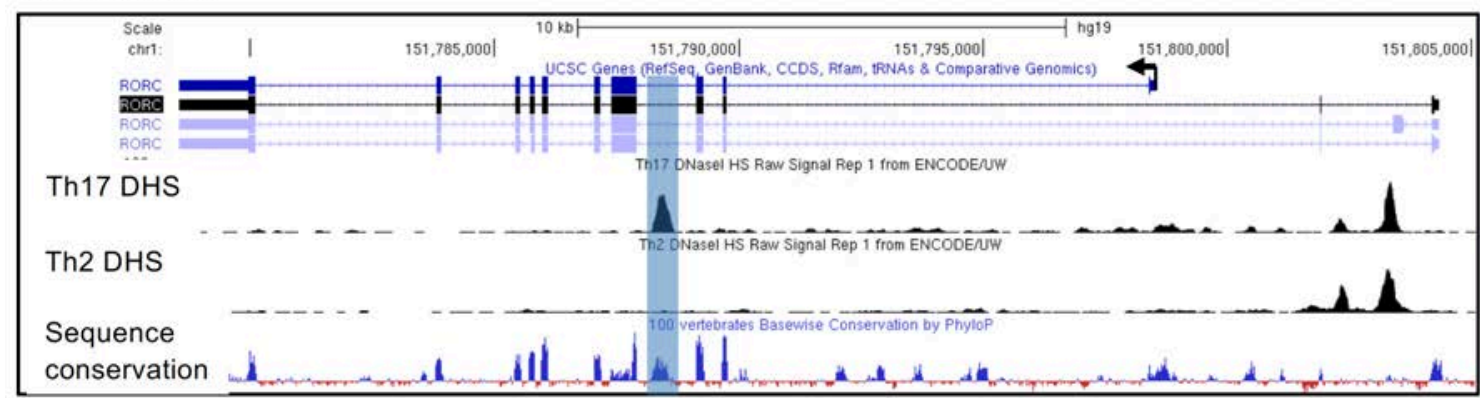

+10kb DHS site +10kb DHS site

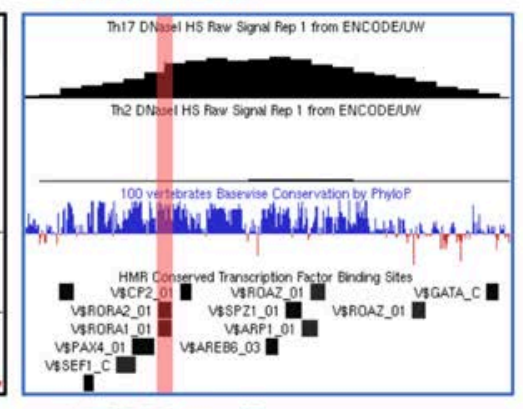

RORE motif 

available under aCC-BY-NC-ND 4.0 International license.

Figure 4. ROR $\alpha$ shares genomic binding sites with ROR $\gamma$ t in Th17 cells.

(A) ChIP-Seq tracks of ROR $\gamma \mathrm{t}$ and ROR $\alpha$ within Th17 effector program genes.

(B) Gene ontology analysis of ROR $\alpha$ direct target genes (Peak(s) found within 10kb of gene body).

(C) ChIP-Seq data exhibiting ROR $\gamma \mathrm{t}$ and ROR $\alpha$ binding to cis-regulatory elements in Rorc locus.

(D) ATAC-Seq data showing open cis-elements in the Rorc locus of in vitro differentiated or ex vivo isolated T cell lineages. Small intestine (SI) or EAE spinal cord (SC) T cells were FACS sorted from /117a ${ }^{e G F P}$ mice gated on TCR $\beta^{+}$then either GFP positive or negative.

(E) UCSC genome browser depicting DNase-Seq on human Th17 (UCSC Accession: wgEncodeEH003020) and Th2 (UCSC Accession: wgEncodeEH000491) from the Encode database aligned with GRCh37/hg19 and the Vertebrate Multiz Alignment \& Conservation (100 Species) and HMR Conserved Transcription Factor Binding Sites tracks. RORC locus (left) and zoomed $+10 \mathrm{~kb}$ DHS site (right).

See also Figure S4. 
bioRxiv preprint doi: https://doi.org/10.1101/2020.12.15.422921; this version posted December 22, 2020. The copyright holder for this preprint (which was not certified by peer review) is the author/funder, who has granted bioRxiv a license to display the preprint in perpetuity. It is made Figure S4.

A Live, Lin neg

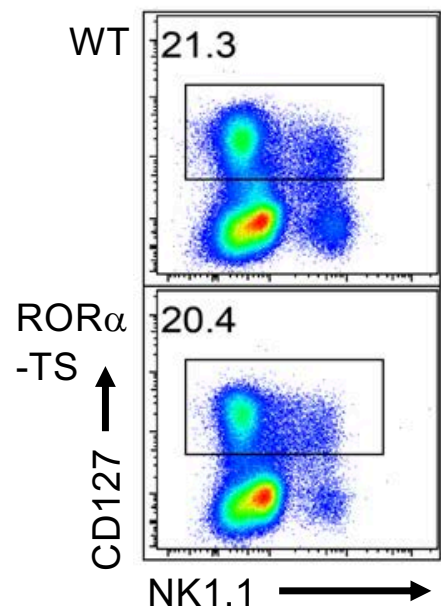

CD127+

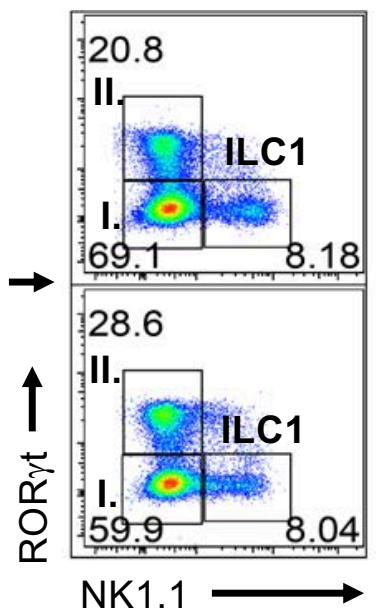

I.

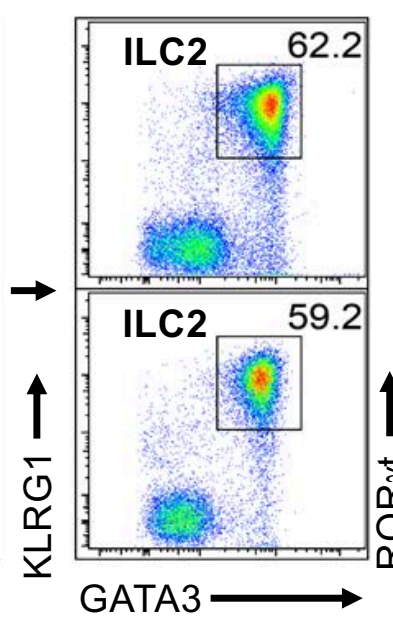

II.
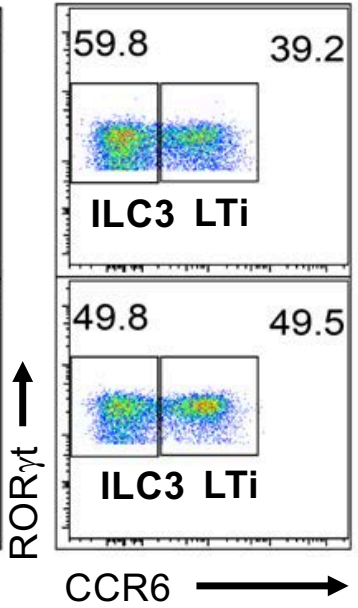

B

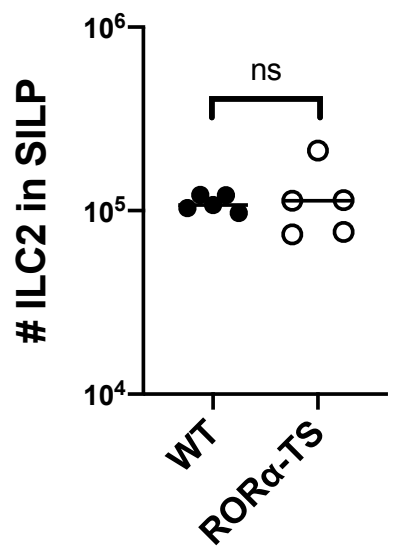

\section{C

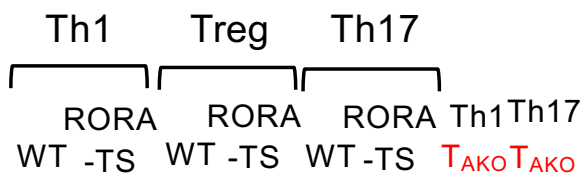

$\mathrm{ROR} \alpha$

$\beta$ Tumulin

\section{E}

ROR $\gamma t$
ChIP

$\mathrm{T}_{\mathrm{WT}}$ $\mathrm{T}_{\mathrm{WT}}$

ROR $\alpha$

(Ciofani et al.) RORA-TS RORA-TS
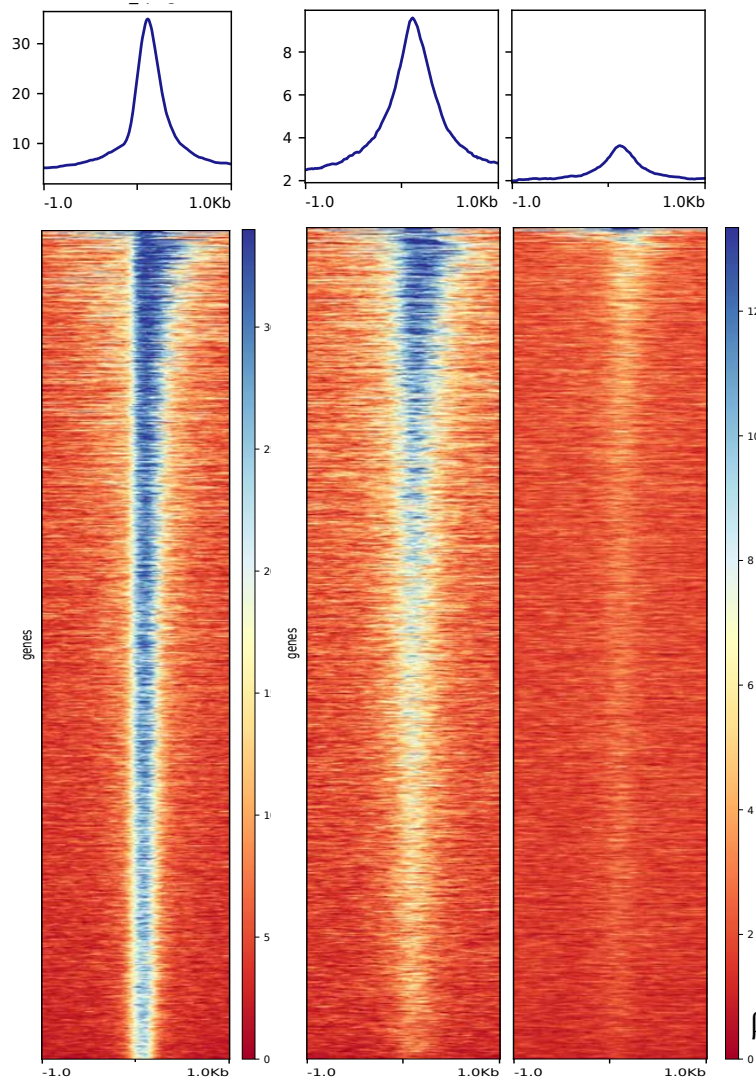

H
$\mathbf{F}$

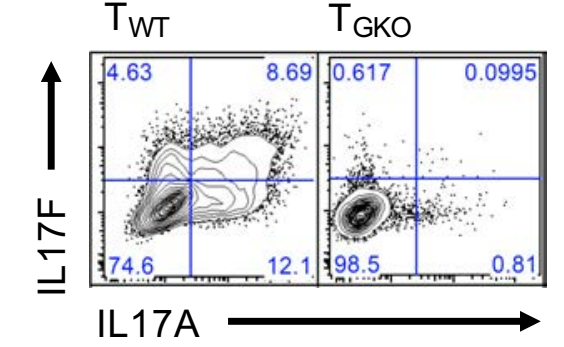

G

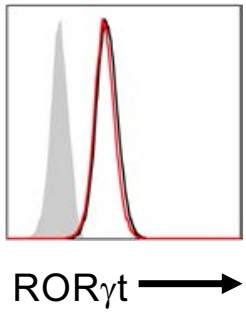

G Rora
WT - Th0

WT -Th17

ROR $\alpha$-TS -Th17

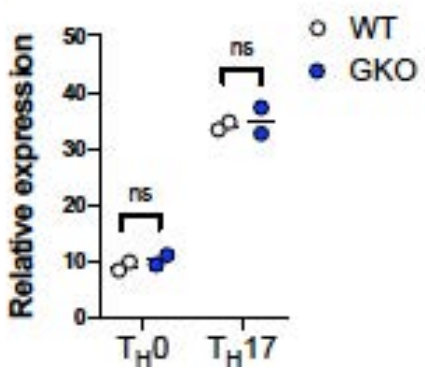

Th1 Treg Th17

$\longrightarrow$

$\mathrm{ROR} \alpha$

$\mathrm{T}_{\mathrm{WT}} \mathrm{T}_{\mathrm{GKO}} \mathrm{T}_{\mathrm{WT}} \mathrm{T}_{\mathrm{GKO}} \mathrm{T}_{\mathrm{WT}} \mathrm{T}_{\mathrm{GKO}}$

$\mathrm{ROR} \gamma \mathrm{t}$

$\beta$ Tubulin

ROR $\gamma$ t

ChIP
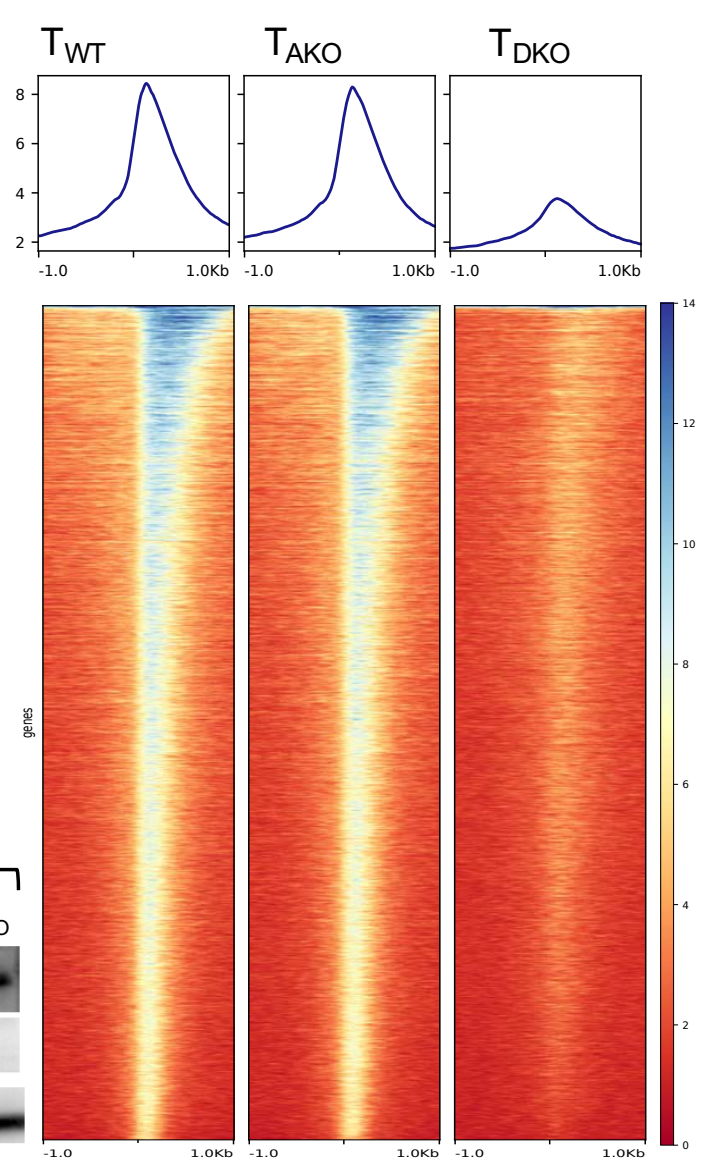
Figure S4. Shared genomic binding sites of ROR $\alpha$ and ROR $\gamma \mathrm{t}$ in Th17 cells. Related to Figure 4.

(A) Gating strategy to identify innate lymphoid cell (ILC) populations in small intestine lamina propria (SILP) of wild type (WT) and RORA-TS mice. Lineage markers (Lin) include CD3, TCR $\beta, T C R \gamma \delta$, CD11b, CD19.

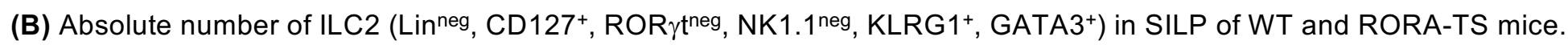

(C) Western blot data displaying intact ROR $\alpha$ expression of in vitro polarized RORA-TS Th17 cells.

(D) Stacked histogram illustrates representative ROR $\gamma$ t expression of in vitro polarized RORA-TS Th17 cells.

(E) Heatmaps depicting genome-wide ROR $\gamma$ t (left) and ROR $\alpha$-TS (middle and right) ChIP-Seq signals of in vitro polarized Th17 cells, centered on the summit of ROR $\gamma$ t binding sites called on the basis of our earlier dataset (Ciofani et al., 2012). Middle and right alignments compare ROR $\alpha$ occupancy in wild-type ( $\left.T_{W T}\right)$ and ROR $\gamma t$-deficient ( $\left.T_{G K O}\right) T$ cells.

(F) Representative FACS plots displaying IL-17A and IL-17F production of in vitro polarized $\mathrm{T}_{\mathrm{WT}}$ or $\mathrm{T}_{\mathrm{GKO}}$ Th17 cells.

(G) qPCR result of Rora gene expression of in vitro polarized $T_{W T}$ and $T_{G K O}$ cells cultured under Th0 (IL2) or Th17 (IL$6+$ TGF- $\beta+$ IL-23) conditions for $48 \mathrm{~h}$.

(H) Immunoblots for ROR $\alpha$ and ROR $\gamma$ t of in vitro polarized $T_{W T}$ and $T_{G K O}$ cells cultured under Th1 (IL-2+IL-12), Treg (IL$2+$ TGF- $\beta$ ) or Th17 (IL-6+TGF- $\beta+$ IL-23) conditions for 48h. $\beta$-Tubulin is shown as a loading control.

(I) Heatmaps representing ROR $\gamma \mathrm{t}$ ChIP-Seq peaks of in vitro polarized $\mathrm{T}_{\mathrm{WT}}$ (left), $\mathrm{T}_{\mathrm{AKO}}$ (middle) and ROR $\alpha / \mathrm{ROR} \gamma \mathrm{t}$ double knock-out ( $\left.\mathrm{T}_{\mathrm{DKO}}\right)$ (right) Th17 cells. 
Figure 5. available under aCC-BY-NC-ND 4.0 International license.

A

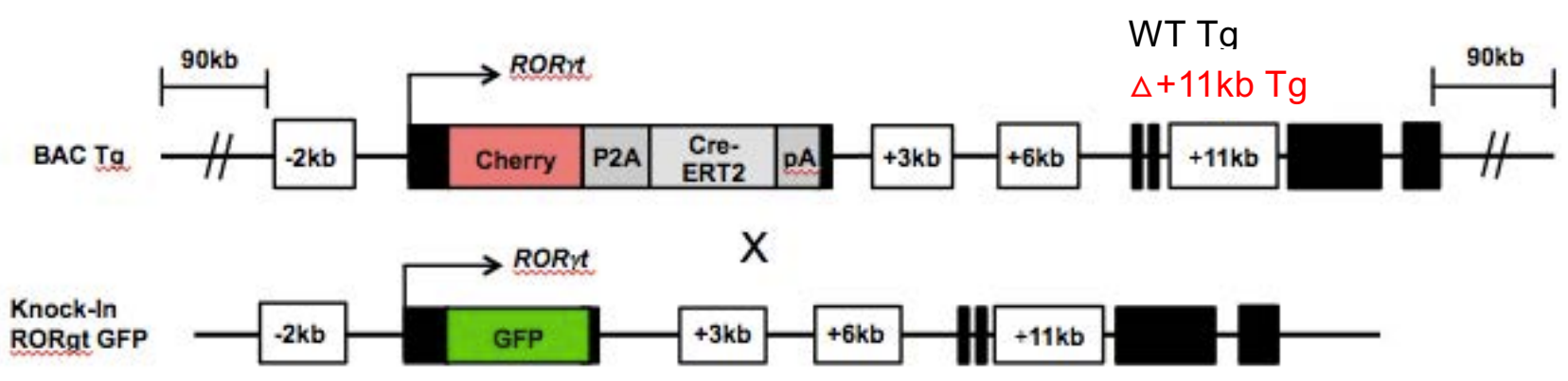

B 96hrs in vitro Th17 differentiation

WT Tg;

Rorc(t)GFP

$\begin{array}{lll} & & \\ \text { Th0 } & \text { Th17 } & \text { Th17 }\end{array}$

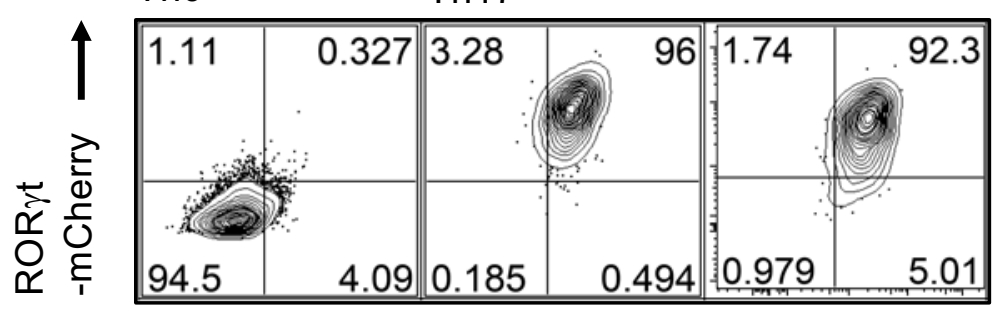

ROR $\gamma$ t-GFP

D CD4 $^{+}{ }^{+} \mathrm{TCR} \beta^{+} \mathrm{T}$ cells from SILP

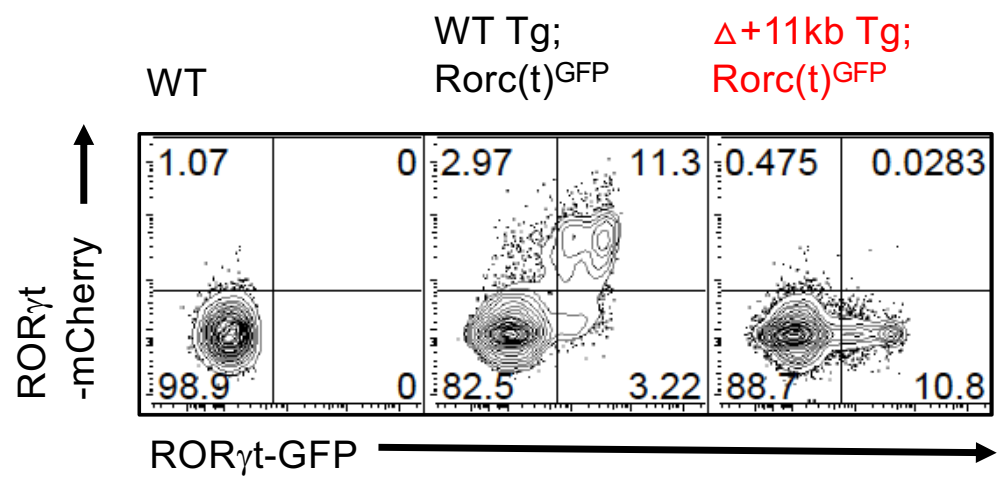

C 96 hrs in vitro Th17 differentiation

WT Tg; Rorc(t)GFP (9192)

$\Delta+11 \mathrm{~kb}$ Tg;Rorc(t) ${ }^{\text {GFP }}$ (4602)

Th0 (348)

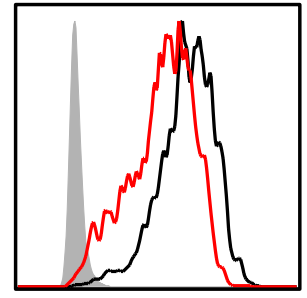

$\mathrm{ROR} \gamma \mathrm{t}$

-mCherry

E Th17 (CD4+TCR $\beta^{+}$Rorc(t) $\left.{ }^{\text {GFP+ }}\right)$ cells from SILP

WT Tg; Rorc(t)GFP (524)

$\Delta+11 \mathrm{~kb}$ Tg; Rorc(t)GFP (42.2)

$\mathrm{T}_{\text {naive }}$ (39.3)

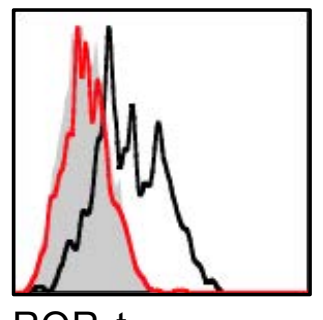

$\mathrm{ROR} \gamma \mathrm{t}$

-mCherry 
Figure 5. The Rorc $+11 \mathrm{~kb}$ cis-element is required for RORyt expression in Th17 cells in vivo, but is dispensable for in vitro differentiation.

(A) Schematic depicting endogenous and BAC transgene allele in WT Tg (Rorc(t)-mCherry); Rorc(t) ${ }^{\text {GFP }}$ control or $+11 \mathrm{~kb}$ enhancer mutant $(\Delta+11 \mathrm{~kb}) \operatorname{Tg}\left(\Delta+11 \mathrm{~kb}\right.$ Rorc(t)-mCherry);Rorc(t) ${ }^{\text {GFP }}$ mice.

(B and C) Flow cytometry plots (B) and stacked histogram (C) illustrate Rorc(t)-mCherry reporter expression in in vitro differentiated Th17 cells from WT Tg; Rorc(t)GFP or $\Delta+11 \mathrm{kbTg}$;Rorc(t) ${ }^{\text {GFP }}$ mice. Geometric mean fluorescence intensities (gMFI) are included in parentheses. Representative data of three experiments.

(D and E) Flow cytometry plots ( $D$ and stacked histogram (E) illustrates Rorc(t)-mCherry reporter expression in ex vivo isolated Th17 (TCR $\beta^{+} \mathrm{ROR}_{\gamma \mathrm{t}^{\mathrm{GFP}}}$ ) cells from SILP of WT Tg (Rorc(t)-mCherry);Rorc(t) ${ }^{\mathrm{GFP}}$ control or $+11 \mathrm{~kb}$ enhancer mutant $(\Delta+11 \mathrm{~kb}) \operatorname{Tg}(\Delta+11 \mathrm{~kb}$ Rorc $(\mathrm{t})-\mathrm{mCherry}) ; \operatorname{Rorc}(\mathrm{t})^{\mathrm{GFP}}$ mice. gMFIs are included in parentheses. Representative data of three experiments.

See also Figure S5. 
bioRxiv preprint doi: https://doi.org/10.1101/2020.12.15.422921; this version posted December 22, 2020. The copyright holder for this preprint (which was not certified by peer review) is the author/funder, who has granted bioRxiv a license to display the preprint in perpetuity. It is made

Figure S5. available under aCC-BY-NC-ND 4.0 International license.

A

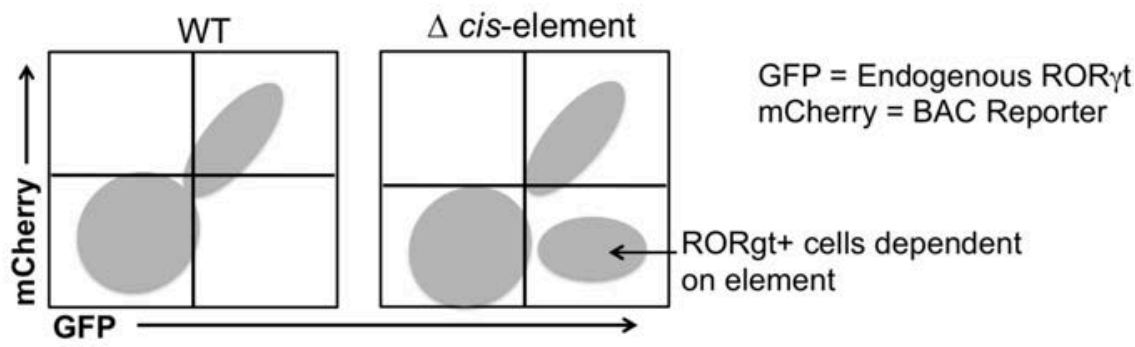

B
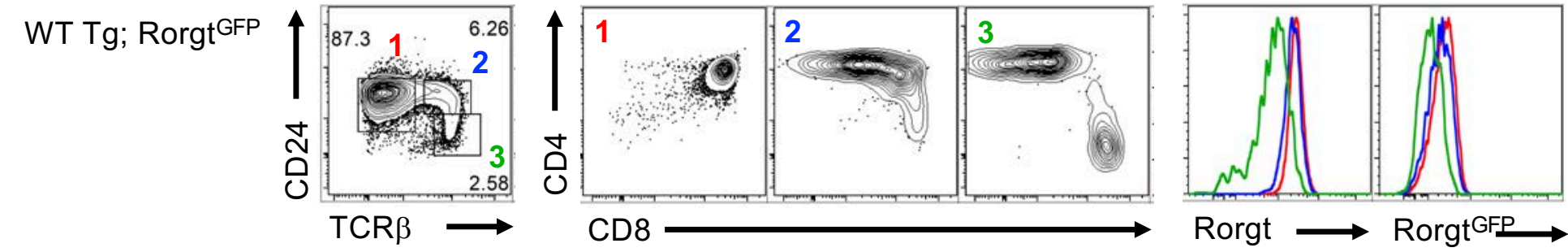

$\Delta+11 \mathrm{kbTg} ;$ RorgtGFP
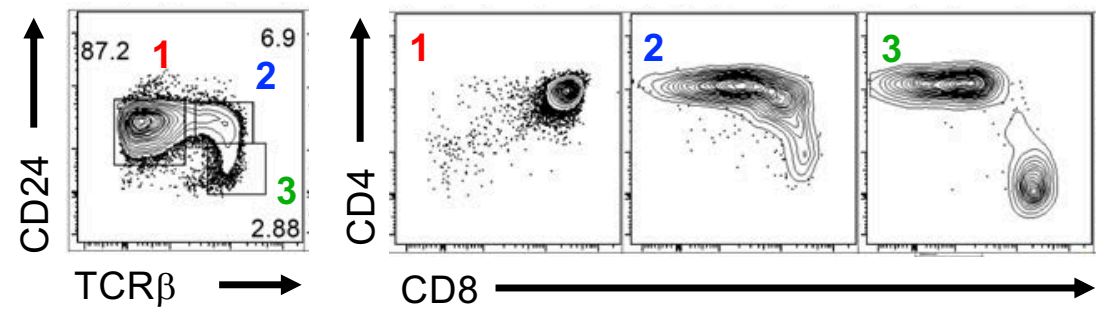
-mCherry

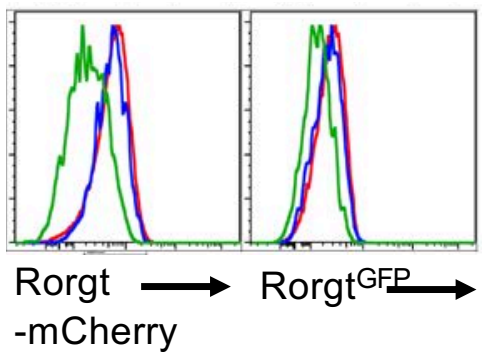

C

Type-17 (ROR $\left.\gamma \mathrm{t}-\mathrm{GFP}^{+}\right)$lineages from SILP

WT Tg; Rorgt ${ }^{\text {GFP }} \quad \Delta+11$ kbTg; RorgtGFP

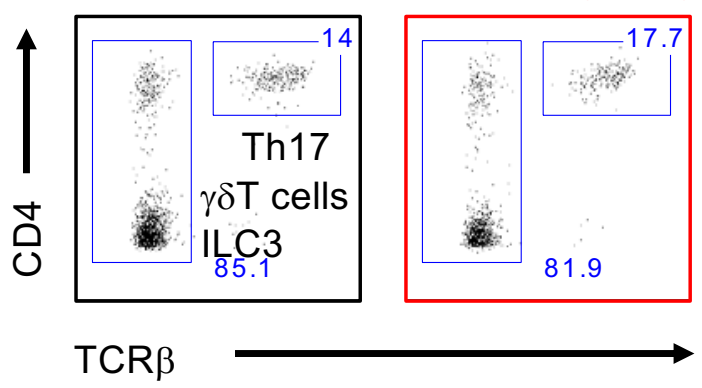

DAPI-CD11b-CD14-CD19-ROR Rt-GFP ${ }^{+}$

E $\gamma \delta$ Th17 cells from SILP

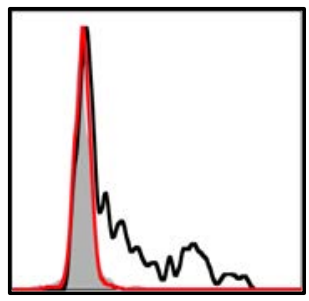

WT Tg; RorgtGFP (393)

$\Delta+11 \mathrm{kbTg}$;RorgtGFP (48)

Non-Th17 (42.1)
D ILC3 from SILP

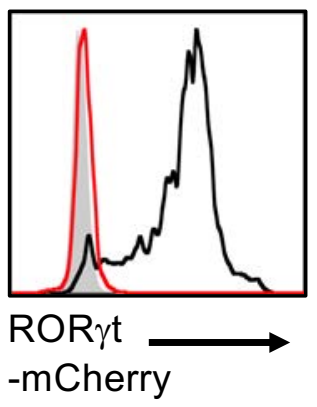

WT Tg; RorgtGFP (2374)

$\Delta+11 \mathrm{kbTg}$;RorgtGFP (44.5)

ILC1/2 (39)

ROR $\gamma \mathrm{t}$ -mCherry 
bioRxiv preprint doi: $h$ ttps://doi.org/10.1101/2020.12.15.422921; this version posted December 22, 2020. The copyright holder for this preprint (which was not certified by peer review) is the author/funder, who has granted bioRxiv a license to display the preprint in perpetuity. It is made

Figure S5. Requirement of Rorc $(t)+11 \mathrm{~kb}$ cis-element for ROR $\gamma$ t expression in Type-17 lymphocytes in vivo.

\section{Related to Figure 5.}

(A) Schematic depicting expression of endogenous and Tg reporter alleles in Rorc(t)-mCherry BAC Tg; Rorc(t) GFP mice.

(B) Flow cytometry plots depicting gating strategy to capture thymocyte development from DP $\left(\mathrm{CD} 4^{+} \mathrm{CD} 8^{+}\right)$stage to postselection stages (left and middle). On the right, mCherry and GFP reporter expression in each color-coded thymocyte subset from indicated $\mathrm{Tg}$ mouse line.

(C) Flow cytometry of indicated populations from the SILP in WT and $+11 \mathrm{~kb}$ enhancer mutant $\operatorname{Tg}(\Delta+11 \mathrm{kbTg})$; Rorc $(t)$ GFP mice.

(D and E) mCherry reporter expression of ex vivo isolated ILC3 (Lin ${ }^{\text {negROR }} \gamma \mathrm{t}^{\mathrm{GFP}+}$ ) cells (D) and $\gamma \delta$ Th17

$\left(\gamma \delta \mathrm{TCR}^{+} \mathrm{ROR} \gamma \mathrm{t}^{\mathrm{GFP}}\right)$ cells $(\mathrm{E})$ from SILP of WT Tg; Rorc $(t)^{\text {GFP }}$ or $\Delta+11 \mathrm{kbTg} ; \operatorname{Rorc}(t)^{\text {GFP }}$ mice. gMFls are included in parentheses. Representative data of three experiments. 
bioRxiv preprint doi: https://doi.org/10.1101/2020.12.15.422921; this version posted December 22,2020 . The copyright holder for this preprint (which was not certified by peer review) is the author/funder, who has granted bioRxiv a license to display the preprint in perpetuity. It is made Figure 6. available under aCC-BY-NC-ND 4.0 International license.

A

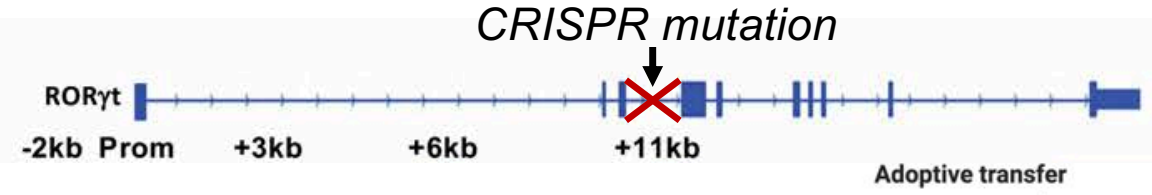

CRISPR mutation
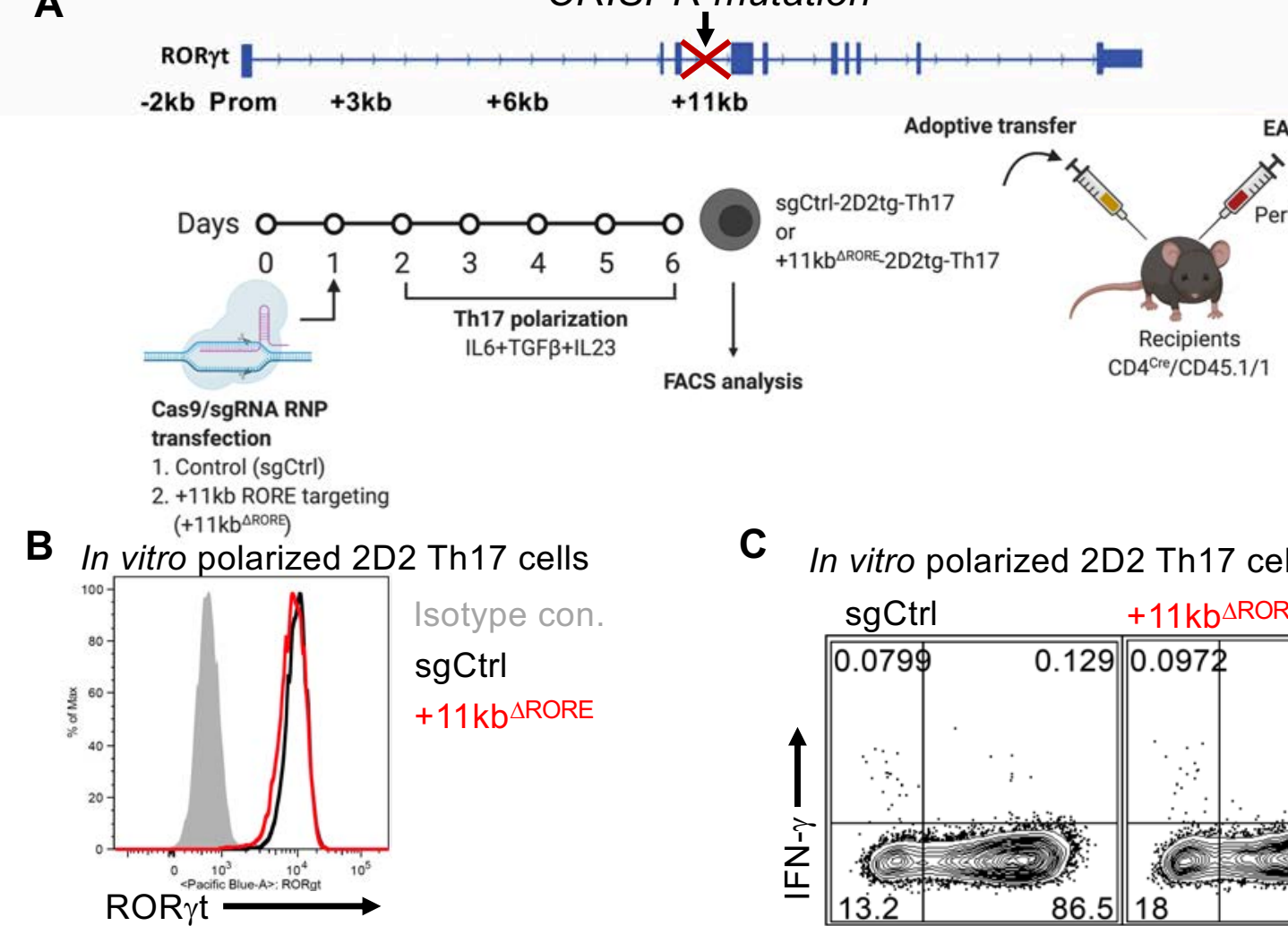

C In vitro polarized 2D2 Th17 cells

D SC at day+17 post immunization (peak disease)

Donor 2D2 cells

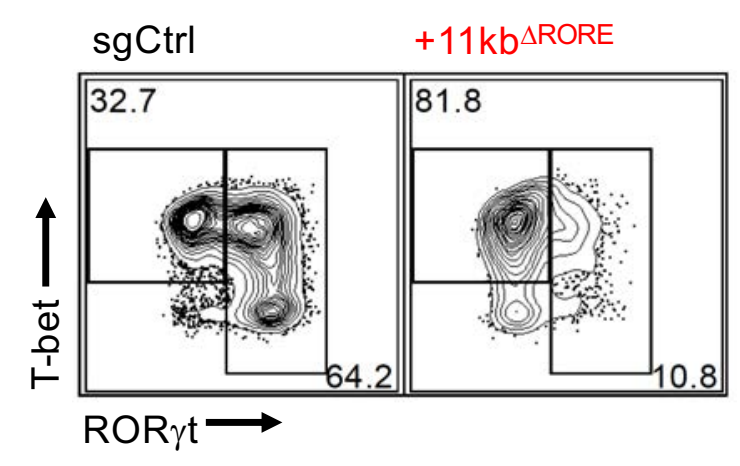

E

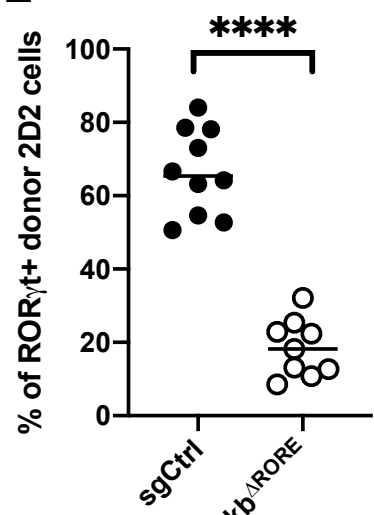

상

H SC at day+17 post immunization (peak disease)

Donor 2D2 cells

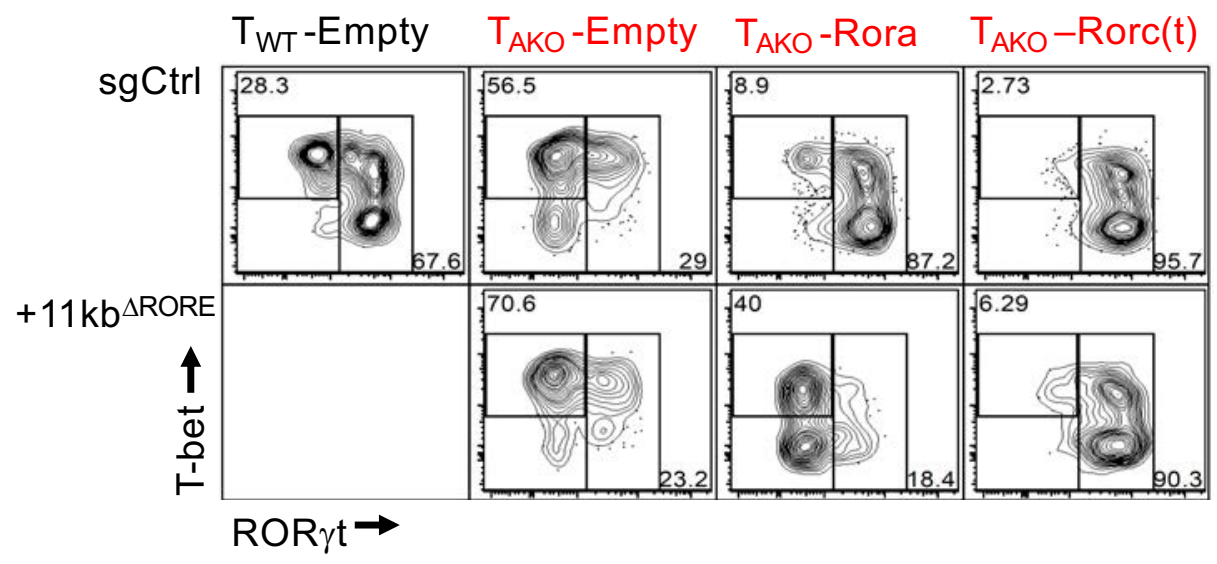

G

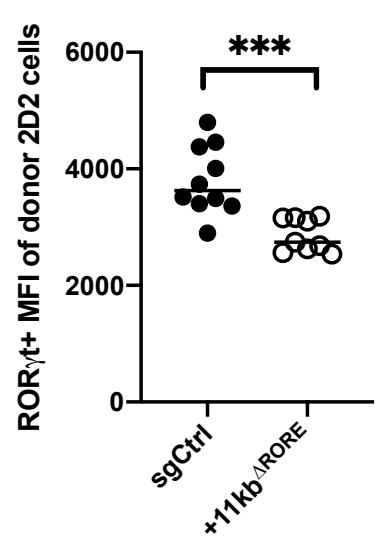


Figure 6. ROR $\alpha$ promotes in vivo Th17 stability through a conserved enhancer located in the $+11 \mathrm{~kb}$ region of the

\section{Rorc(t) locus}

(A) Experimental scheme to interrogate the role of the Rorc $+11 \mathrm{~kb}$ element in vivo.

(B) Stacked histogram illustrates ROR $\gamma \mathrm{t}$ expression in control (sgRNA control; sgCtrl) and Rorc(t) $+11 \mathrm{~kb}$ enhancer mutant (sgRNA that target RORE in $+11 \mathrm{~kb}$ cis-element of $\operatorname{Rorc}(t) ;+11 \mathrm{~kb} \triangle \mathrm{RORE}$ ) in vitro differentiated 2D2tg Th17 cells.

(C) Representative FACS plots displaying IL-17A and IFN $\gamma$ production of in vitro polarized Th17 sgCtrl or $+11 \mathrm{~kb} \triangle \mathrm{RORE}$ 2D2tg cells.

(D) Representative flow cytometry analysis of ROR $\gamma$ t and T-bet expression in sgCtrl and $+11 \mathrm{~kb} \triangle \mathrm{RORE}$ donor-derived $2 \mathrm{D} 2 \mathrm{tg}$ cells in SC at peak of EAE.

(E-G) Frequency (E), number (F) and ROR $\gamma \mathrm{tgMFI}(\mathrm{G})$ of ROR $\gamma \mathrm{t}$-expressing sgCtrl or $+11 \mathrm{~kb} \triangle \mathrm{RORE} 2 \mathrm{D} 2 \mathrm{tg}$ cells in SC at peak of EAE. Summary of 2 experiments, with $\operatorname{sgCtrl}(n=10)$ and $+11 \mathrm{~kb} \triangle \operatorname{RORE}(n=9)$ recipients.

(H and I) Flow cytometry analysis of ROR $\gamma$ t and T-bet expression $(\mathrm{H})$ and frequency of ROR $\gamma$ t expression (I) in sgCtrl or $+11 \mathrm{~kb}^{\triangle R O R E} \mathrm{~T}_{\mathrm{AKO}}$ donor-derived 2D2tg cells, retrovirally reconstituted with Rora or Rorgt, in SC at peak of EAE. Summary of 2 experiments, with $\mathrm{T}_{\mathrm{WT}}$-sgCtrl-Empty: $\mathrm{T}_{\mathrm{AKO}}-\mathrm{sgCtrl-Empty}(\mathrm{n}=4), \mathrm{T}_{\mathrm{WT}}-\mathrm{sgCtrl-Empty:} \mathrm{T}_{\mathrm{AKO}}$-sgCtrl-Rora $(\mathrm{n}=4)$, $\mathrm{T}_{\mathrm{WT}}-\mathrm{sgCtrl-}$

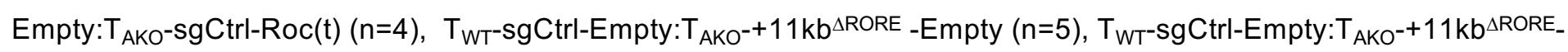
Rora ( $n=5), T_{W T}$-sgCtrl-Empty: $T_{A K O^{-}}+11 \mathrm{~kb} \Delta{ }^{\Delta R O R E}-\operatorname{Roc}(t)(n=5)$ recipients.

Statistics were calculated using the unpaired sample $T$ test. Error bars denote the mean \pm s.e.m. ns $=$ not significant, ${ }^{*} p<$ $0.05,{ }^{* *} p<0.01,{ }^{* * *} p<0.001,{ }^{* * * *} p<0.0001$.

See also Figure S6. 
bioRxiv preprint doi: https://doi.org/10.1101/2020.12.15.422921; this version posted December 22, 2020. The copyright holder for this preprint (which was not certified by peer review) is the author/funder, who has granted bioRxiv a license to display the preprint in perpetuity. It is made Figure S6. available under aCC-BY-NC-ND 4.0 International license.

\section{A}

T7 endonuclease assay

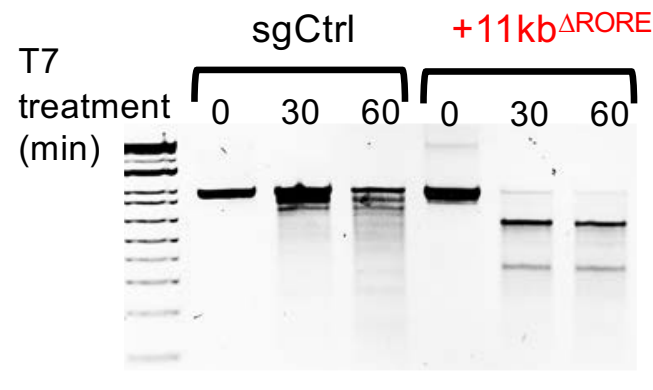

B Mutation in RORE of $+11 \mathrm{~kb}$ cis-element of $\operatorname{Rorc}(t)$ locus (10/10) $R O R$ binding motif ( $R O R E$ )

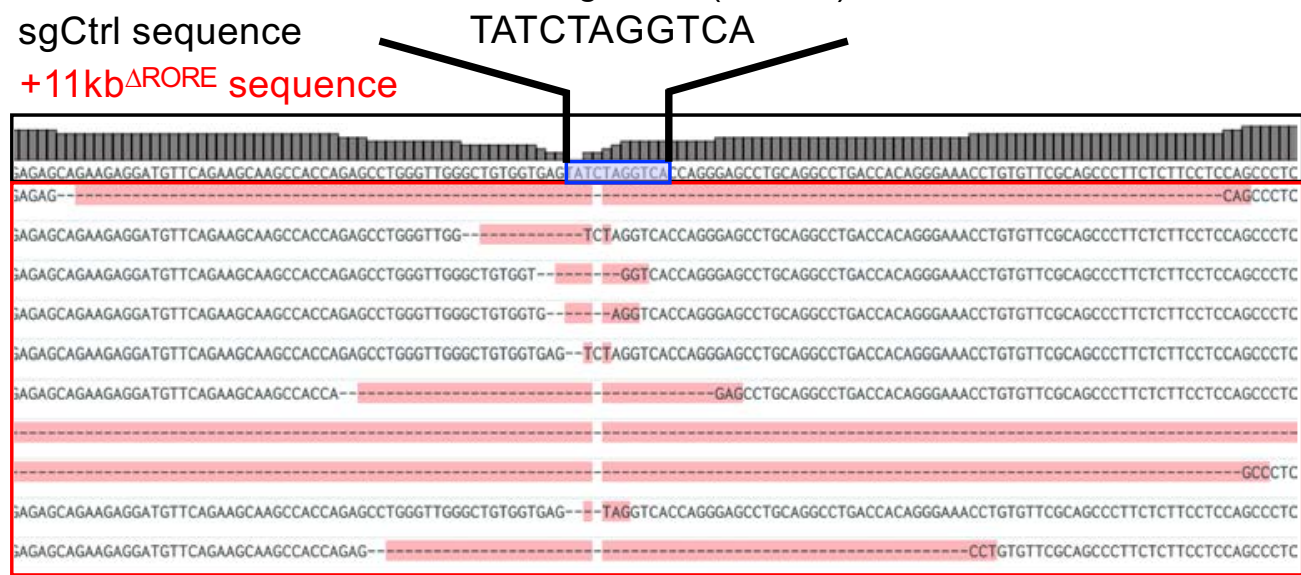

C

2D2 $\mathrm{T}_{\mathrm{WT}}: 2 \mathrm{D} 2 / \mathrm{CD}^{4}{ }^{\text {cre }} / \mathrm{CD} 45.1 / 2$

$2 \mathrm{D} 2 \mathrm{~T}_{\text {AKO }}: 2 \mathrm{D} 2 / \mathrm{CD}^{\mathrm{Cre}} /$ Rora $^{\mathrm{f} / \mathrm{f} / \mathrm{CD}} 45.2 / 2$

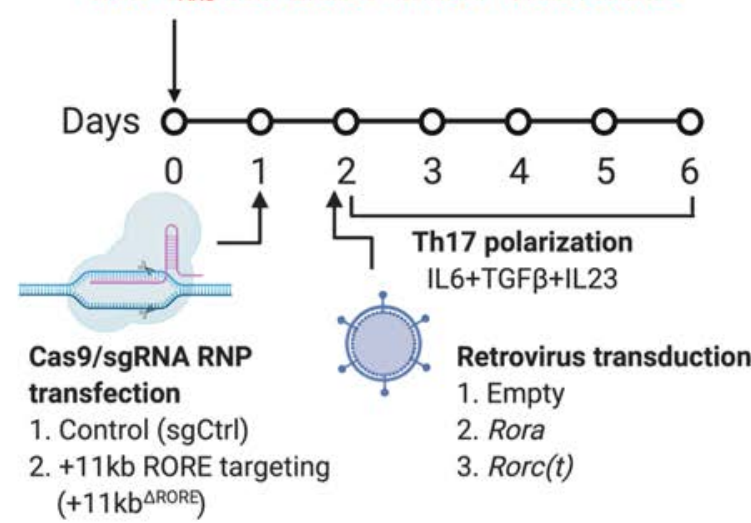

1:1 adoptive transfer

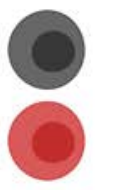

TwT-sgCtrl-Empty

$\mathrm{T}_{\text {AKO-SgCtrl-Empty }}$

or $\mathrm{T}_{\mathrm{AKO}}$-sgCtrl-Rora or $\mathrm{T}_{\text {AKO }}$-sgCtrl-Rorc(t) or $\mathrm{T}_{\text {AKO }}+11 \mathrm{~kb}^{\triangle \mathrm{RORE}}$ Empty

or $\mathrm{T}_{\text {AKO }}+11 \mathrm{~kb} \mathrm{BRORE}_{\text {-Rora }}$

or $T_{\text {AKO }}+11 k^{\triangle R O R E}-\operatorname{Rorc}(t)$

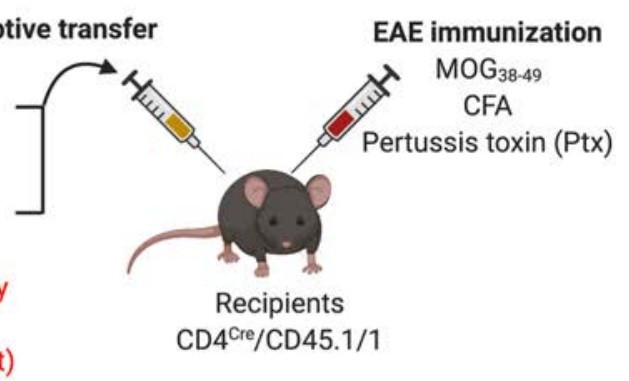

Figure S6. Efficient editing of Rorc $(t)+11 \mathrm{~kb}$ cis-element by CAS9-RNP method. Related to Figure 6.

(A) Analysis of CAS9/gRNA RNP-mediated targeting efficiency of $+11 \mathrm{~kb}$ enhancer by T7 endonuclease I assay.

(B) Sanger sequencing results displaying $\operatorname{Rorc}(t)+11 \mathrm{~kb}$ enhancer mutations and deletions of $\mathrm{T}_{\mathrm{AKO}}+11 \mathrm{~kb} \Delta \mathrm{RORE} 2 \mathrm{D} 2 \mathrm{tg}-\mathrm{Th} 17$ cells.

(C) Experimental scheme to examine the role of $\operatorname{Rorc}(t)+11 \mathrm{~kb}$ cis-element in maintenance of pathogenic Th17 program during EAE. 